\title{
Climate Change during and after the Roman Empire: Reconstructing the Past from Scientific and Historical Evidence
}

\section{Citation}

McCormick, Michael, Ulf Büntgen, Mark A. Cane, Edward R. Cook, Kyle Harper, Peter John Huybers, Thomas Litt, et al. 2012. "Climate Change during and after the Roman Empire: Reconstructing the Past from Scientific and Historical Evidence." Journal of Interdisciplinary History 43 (2) (August): 169-220. doi:10.1162/JINH_a_00379. http://dx.doi.org/10.1162/ JINH_a_00379.

\section{Published Version}

doi:10.1162/JINH_a_00379

\section{Permanent link}

http://nrs.harvard.edu/urn-3:HUL.InstRepos:11642550

\section{Terms of Use}

This article was downloaded from Harvard University's DASH repository, and is made available under the terms and conditions applicable to Other Posted Material, as set forth at http:// nrs.harvard.edu/urn-3:HUL.InstRepos:dash.current.terms-of-use\#LAA

\section{Share Your Story}

The Harvard community has made this article openly available. Please share how this access benefits you. Submit a story. 
Journal of Interdisciplinary History, XLIII:2 (Autumn, 20I2), I69-220.

Michael McCormick, Ulf Büntgen, Mark A. Cane, Edward R. Cook, Kyle Harper, Peter Huybers, Thomas Litt, Sturt W. Manning, Paul Andrew Mayewski, Alexander F. M. More, Kurt Nicolussi, Willy Tegel

\section{Climate Change during and after the Roman Empire: Reconstructing the Past from Scientific and Historical Evidence When this journal pioneered the} study of history and climate in I979, the questions quickly outstripped contemporary science and history. Today climate science uses a formidable and expanding array of new methods to measure pre-modern environments, and to open the way to exploring how

Michael McCormick is Francis Goelet Professor of Medieval History, Harvard University. He is the author of Origins of the European Economy: Communications and Commerce, A.D. 300-900 (New York, 2002); "History's Changing Climate: Climate Science, Genomics, and the Emerging Consilient Approach to Interdisciplinary History," Journal of Interdisciplinary History, XLII (20II), 25I-273.

Ulf Büntgen is Scientific Researcher, Swiss Federal Research Institute wsL and the OcCR, University of Bern. He is the author of, with H. Kauserud and S. Egli, "Linking Mushroom Productivity and Phenology to Climate Variability," Frontiers in Ecology and the Environment, X (20I2), I4-I9.

Mark A. Cane is G. Unger Vetlesen Professor of Earth and Climate Sciences and Director, Master of Arts Program in Climate and Society, Lamont-Doherty Earth Observatory, Columbia University. He is the author of, with S. Hsiang et al., "Civil Conflicts Are Associated with the Global Climate," Nature, 476 (20I I), 438-44I.

Edward R. Cook is Ewing Lamont Research Professor, Lamont-Doherty Earth Observatory, Columbia University. He is the author of, with R. Seager et al., "Megadroughts in North America: Placing IPCC Projections of Hydroclimatic Change In A Long-Term Paleoclimate Context," Journal of Quaternary Science, XXV (2010), 48-6I.

Kyle Harper is Assistant Professor of Classics and Letters, University of Oklahoma, Norman. He is the author of Slavery in the Late Roman World, AD 275-425 (New York, 20I I).

Peter Huybers is Professor of Earth and Planetary Sciences, Harvard University. He is the author of, with Cristian Proistosescu and Adam C. Maloof, "To Tune or Not to Tune: Detecting Orbital Variability in Oligo-Miocene Climate Records," Earth and Planetary Science Letters," 325/326 (2012), I00-I07.

Thomas Litt is Professor of Palaeobotany, University of Bonn. He is the author of, with C. Schölzel et al., "Vegetation and Climate History in the Westeifel Volcanic Field (Germany) during the Last I I, ooo Years Based on Annually Laminated Lacustrine Sediments," Boreas, XXXVIII (2009), 679-690.

Sturt W. Manning is Goldwin Smith Professor of Classical Archaeology and Director of the Malcolm and Carolyn Wiener Laboratory for Aegean and Near Eastern Dendrochronology, Cornell Tree Ring Laboratory, Cornell University. He is the author of, with Andrew Manning et al., The Late Roman Church at Maroni Petrera: Survey and Salvage Excavations 19901997, and Other Traces of Roman Remains in the Lower Maroni Valley, Cyprus (Nicosia, 2002).

Paul Andrew Mayewski is Professor and Director, Climate Change Institute, University of Maine. He is the author of, with M. C. Morrison, Journey into Climate: Exploration, Adventure and the Unmasking of Human Innocence (Santa Fe, 20I I). 
environments shaped the human experience-and vice versa-in contexts as different as the Little Ice Age and the Maya collapse. But these new methods are diverse, complex, and highly technical. The natural-scientific literature seemingly or actually offers contradictory claims or draws sweeping historical inferences from slender evidence; alarmed historians and archaeologists understandably struggle with evaluating highly technical scientific analyses and methods, sometimes failing to understand them at an elementary level. Climate and history impose an interdisciplinary approach. This article continues that earlier exploration by testing hypotheses concerning the rise and fall of Rome. ${ }^{1}$

The possible effect of climate change on the expansion and fall of Rome has long intrigued historians. Recent developments in the study of modern climates intensify that interest, and conferences, compilations, and monographic studies involving the ancient climate appear at an accelerating rate. ${ }^{2}$

Alexander F. M. More is a Ph.D. candidate, Department of History, Harvard University. He is the author of "Civic Medicine" and "Averroës," in Robert E. Bjork (ed.), Oxford Dictionary of the Middle Ages (New York, 2008).

Kurt Nicolussi is Associate Professor, Institute of Geography, Innsbruck University. He is the author of, with Ulf Büntgen et al., "2500 Years of European Climate Variability and Human Susceptibility,” Science, CCCXXXI (20I I), 578-582.

Willy Tegel is Researcher, Institute for Forest Growth, University of Freiburg. He is the author of, with Ulf Büntgen et al., "2500 Years of European Climate Variability and Human Susceptibility," Science, CCCXXXI (201 I), 578-582.

(C) 2012 by the Massachusetts Institute of Technology and The Journal of Interdisciplinary History, Inc.

Color versions of the figures appearing in this article are available at http://www. mitpressjournals.org/doi/suppl/IO.I I62/JINH_a_00379.

I See the special issue, "History and Climate," Journal of Interdisciplinary History, X (1980), 58I-858. Wolfgang Behringer et al., (eds.), Kulturelle Konsequenzen der "Kleinen Eiszeit" (Göttingen, 2005); Daniel H. Sandweiss and Jeffrey Quilter (eds.), El Niño, Catastrophism, and Culture Change in Ancient America (Washington, D.C., 2008); Norman Hammond, "Climate, Crisis, Collapse, and Ancient Maya Civilization: An Enduring Debate," in A. Bruce Mainwaring et al. (eds.), Climate Crises in Human History (Philadelphia, 2010), I89-196. Walter Scheidel, "Approaching the Roman Economy," Princeton/Stanford Working Papers in Classics (2010)—http://www.princeton.edu/ pswpc/pdfs/scheidel/o9I007.pdf (cited August 22, 2010)-judiciously raises the question of climate's impact on the Roman economy and then is forced simply to tabulate different scientific publications. Paolo Squatriti, "The Floods of 589 and Climate Change at the Beginning of the Middle Ages: An Italian Microhistory," Speculum, LXXXV (2010), 799-826, asserts that efforts to compare medieval written evidence with scientific proxy data correspond to an "optimistic view" that "is not always warranted" but offers no contradictory evidence to the studies that he cites as exemplifying "this sanguine scholarship" (803 and n. I6); he seems unfamiliar enough with the scientific data to misunderstand studies of volcanism as being based on $\delta^{18} \mathrm{O}$ isotopes (809 and n. 39).

2 See Ellsworth Huntington, "Climatic Change and Agricultural Exhaustion as Elements in 
Previous historical and archaeological discussion has mostly been limited to written records surviving from the Roman Empire and its successors, occasionally leavened by attention to climate dynamics. The ancient and early medieval written records are fairly abundant but unevenly preserved; by themselves, they rarely

the Fall of Rome," Quarterly Journal of Economics, XXXI (I9I7), I73-208, who presciently considered California tree rings and Asian lake levels; cf. Alexander Demandt, Der Fall Roms: die Aufösung des römischen Reiches im Urteil der Nachwelt (Munich, I984), 376; idem, Die Spätantike: römische Geschichte von Diocletian bis Justinian, 284-565 n. Chr. (Munich, 2007), 597. Hubert H. Lamb, Climate, History and the Modern World (London, I995; orig. pub. I982), I56-I69, displayed an uncanny knack for discerning significant patterns from sparse written evidence and his own grasp of weather patterns affecting the Roman world. Two important and complementary compilations present the written records for the later Roman Empire, particularly its eastern provinces, from 300 A.D. onward: Ioannes G. Teleles, Meteorologika phainomena kai klima sto Vyzantio (Athens, 2004), 2 v.; Dionysios Ch. Stathakopoulos, Famine and Pestilence in the Late Roman and Early Byzantine Empire: A Systematic Survey of Subsistence Crises and Epidemics (Aldershot, 2004). Older compilations are useful but less reliable: Richard Hennig, Katalog bemerkenswerter Witterungsereignisse von den ältesten Zeiten bis zum Jahre 1800 (Berlin, I904); Curt Weikinn, Quellentexte zur Witterungsgeschichte Europas von der Zeitwende bis zum Jahre 1850 (Berlin, I958), $4 \mathrm{v}$.

Ella Hermon (ed.), Société et climats dans l'Empire romain: pour une perspective historique et systémique de la gestion des ressources en eau dans l'Empire romain (Naples, 2009), comprises essays from a conference that addressed the theme of the Roman climate, and the subject figured prominently in another conference held at the American Academy in Rome, 20I I: William V. Harris (ed.), The Ancient Mediterranean Environment between Science and History (in press).

Some studies have focused on climate conditions at particular moments: Burghart Schmidt, "Der Jahrhundert Sommer im Jahr 49 n. Chr. im Rheinland," Kölner Jahrbuch, XLIII (2010), 695-699; idem and Wolfgang Gruhle, "Niederschlagsschwankungen in Westeuropa während der letzten 8000 Jahre: Versuch einer Rekonstruktion mit Hilfe eines neuen dendrochronologischen Verfahrens," Archäologisches Korrespondenzblatt, XXXIII (2003), 28 I300; idem et al., "Mögliche Schwankungen von Getreideerträgen-Befunde zur Rheinischen Linienbandkeramik und Römischen Kaiserzeit," Archäologisches Korrespondenzblatt, XXXV (2005), 30I-3 I6; Johannes Koder, "Climatic Change in the Fifth and Sixth Centuries?" in Pauline Allen and Elizabeth M. Jeffreys (eds.), The Sixth Century: End or Beginning? (Brisbane, I996), 270-285.

The 536 event has a bibliography all its own: Joel D. Gunn (ed.), The Years without Summer: Tracing A.D. 536 and Its Aftermath (New York, 2000); Antti Arjava, "The Mystery Cloud of 536 CE in the Mediterranean Sources," Dumbarton Oaks Papers, LIX (2005), 73-93. L. B. Larsen et al., "New Ice Core Evidence for a Volcanic Cause of the A.D. 536 Dust Veil," Geophysical Research Letters, XXXV (2008), Lo4708.

A compelling recent contribution studies volcanism and Roman history to the fourth century A.D.: Benoit Rossignol and Sébastien Durost, "Volcanisme global et variations climatiques de courte durée dans l'histoire romaine ( ${ }^{\text {er }}$ s. av. J.-C.- IV ${ }^{\text {ème }}$ s. ap. J.-C.): leçons d'une archive glaciaire (GISP2)," Jahrbuch des römisch-germanischen Zentralmuseums Mainz, LIV (2007), 395-438. See also Sébastien Durost et al., "Climat, Guerre des Gaules et dendrochronologie du chêne (Quercus sp.) du I ${ }^{\text {er }}$ siècle av. J.C.," ArchéoSciences, XXXII (2008), 3 I50. For a similar approach for a later period, see McCormick et al., "Volcanoes and the Climate Forcing of Carolingian Europe, A.D. 750-950," Speculum, LXXXII (2007), 865-895.

Other studies have focused on environmental conditions in particular regions of the Roman Empire. For the northwestern provinces, Jochen Haas, Die Umweltkrise des 3. Jahrhundert 
allow robust serial analyses and corresponding inferences about climate change and trends. The archaeological documentation is potentially rich, but its rigorous exploitation has barely begun. ${ }^{3}$

In order to examine both the relevant substantive and evidentiary questions from a common baseline, climate scientists, historians, and archaeologists convened at Dumbarton Oaks, Harvard's center for Byzantine studies in Washington, D.C., to examine the diverse types of evidence in which each of them specializes, as well as the inferences that the data presently allow. This article represents a kind of "white paper," presenting the first multi-proxy baseline synthesis of what is now known with some confidence about climate conditions across the Roman and post-Roman world from c. IOO B.C. to 800 A.D. ${ }^{4}$

Previous scientific discussion has either been limited to one data set or one area of a tricontinental agrarian Empire with significant commercial and industrial sectors, or it has lacked sufficient chronological resolution to permit robust historical assessments. To create the first evaluation of climate conditions across

n. Chr. im Nordwesten des Imperium Romanum: interdisziplinäre Studien zu einem Aspekt der allgemeinen Reichskrise im Bereich der beiden Germaniae sowie der Belgica und der Raetia (Stuttgart, 2006), explored a selection of natural-scientific, historical, and archaeological evidence for environmental aspects of the crisis in the third century; Josef Klostermann, "Klima und Landschaft am römischen Niederrhein," in Thomas Grünewald and Hans-Joachim Schalles (eds.), Germania inferior: Besiedlung, Gesellschaft und Wirtschaft an der Grenze der römischgermanischen Welt (Berlin, 200I), 36-53, offers an overview of several scientific methods relevant to this region. For the Roman east, see Yizhar Hirschfeld, "A Climatic Change in the Early Byzantine Period? Some Archaeological Evidence," Palestine Exploration Quarterly, CXXXVI (2004), I33-I49; Revital Bookman (Ken-Tor) et al., "Late Holocene Lake Levels of the Dead Sea," Geological Society of America Bulletin, CXVI (2004), 555-57I; Claudia Migowski et al., "Holocene Climate Variability and Cultural Evolution in the Near East from the Dead Sea Sedimentary Record," Quaternary Research, LXVI (2006), 42 I-43I; Telelis, "Climatic Fluctuations in the Eastern Mediterranean and the Middle East AD 300-I 500 from Byzantine Documentary and Proxy Physical Paleoclimatic Evidence-a Comparison," Jahrbuch der österreichischen Byzantinistik, LVIII (2008), I67-207, developed a comparison of a selection of proxy data and written evidence for the eastern Mediterranean. See also Stathakopoulos, "Reconstructing the Climate of the Byzantine World: State of the Problem and Case Studies," in József Laszlovszky and Péter Szabó (eds.), People and Nature in Historical Perspective (Budapest, 2003), 247-26I.

3 See Appendix (I) herein for valuable examples.

4 The Dumbarton Oaks meeting was held in 2009 with the support of McCormick's Distinguished Achievement Award from the Andrew W. Mellon Foundation and of Dumbarton Oaks, particularly Jan Ziolkowski, its director. New climate data and syntheses appear constantly, and much has already come out since this study was completed in 20 I I. See, notably, J. Luterbacher et al., "A Review of 2000 Years of Paleoclimatic Evidence in the Mediterranean," in P. Lionello (ed.), The Climate of the Mediterranean Region: From the Past to the Future (Amsterdam, 20I2), 87-I85. 
the entire Roman Empire, we instead compared the implications of multiple independent proxy data sets. The point was, first, to determine whether general climate conditions can be evaluated across the Roman Empire and its successors from about IOO B.C. to 800 A.D., and if so, whether, when, and how they changed, particularly with respect to potential differences between the western and eastern parts of an Empire that spanned three continents. Second, notwithstanding the fact that the present state of knowledge does not favor a simplistic unraveling of the complex interactions of environmental, economic, political, and cultural developments, the unquestionable sensitivity of the Roman economy's agrarian base to climatic factors provides an important potential link between historical and environmental change. Does the timing of climate change invite comparison with known historical developments?

This article offers provisional answers to such questions at a time when new knowledge is rapidly developing. For the benefit of historians, climate scientists, and archaeologists, it sketches the main features of changing climate patterns throughout the 900year period under review as well as is currently possible from eleven different and independent series of scientific and historical evidence. The picture will certainly change as more data are collected and analyzed, but we have come a long way. The Appendix presents the types of evidence on which this study is founded in terms that should be intelligible to humanists and social scientists.

Proxy data deriving from tree rings, ice cores, speleothems, lake varves, etc., comprise the foundation of the natural-scientific investigation of past climates. Comparison of the proxies with instrumental records of climate during the last century or so has revealed consistent relationships between, for example, the width of central European oak-tree rings and precipitation levels in April, May, and June (hereinafter AMJ). The assumption that those relationships and the underlying mechanisms have remained constant allows climatologists to extrapolate climate data from similar proxy signals for periods when no instrumental records survive. The rapidly growing precision and detail of the proxy data is mind-boggling. Concerning tree rings, a new record based on 7,000 trees from central Europe has allowed estimates of AMJ precipitation levels for every year between 398 B.C. and 2000 A.D. ${ }^{5}$

5 Büntgen et al., "2500 Years of European Climate Variability and Human Susceptibility," Science, CCCXXXI (201 I), 578-582. 
The climate is always changing, but the degree, frequency, and location of the changes vary significantly. Relative to the late Holocene period, multiproxy indicators point to a low range of variability from IоO B.C. to 800 A.D. But even small changes in the overall scope of Holocene climate variability can, under certain conditions, have notable effects on civilizations. For instance, relatively slight perturbations in an otherwise quiescent period might prove deleterious if a society relies on a fine margin of climatic stability. A collection of indicators of past conditions assembled from Greenland ice cores, fluctuations in solar radiation, speleothems from Austria and Turkey, tree-ring series from central Europe and Asia, Austrian and other Alpine glacier movements, varve records from European and western Asian lakes, and written and archaeological records allow a preliminary geographically differentiated assessment of climate change under the Roman Empire with chronological resolution at centenary, decadal, or annual levels (see the Appendix for explanations of each).

We synthesize the results for the entire sweep of Roman imperial history in four multi-century phases, distinguishing between the western (approximately $-9.34^{\circ}$ to $\left.22^{\circ}\right)$ and the eastern $\left(22^{\circ}\right.$ to $38.96^{\circ}$ ) regions of the Empire. The written, archaeological, and natural-scientific proxy evidence independently but consistently indicates that climate conditions changed during the period of the Roman Empire's maximum expansion and final crisis. Rates of change shifted dramatically over time, from apparent near stasis under the early Empire to rapid fluctuations later in the Empire's history. Changes affected different parts of the Empire in different ways and at different times. Even though the different data sets are not in perfect agreement about absolute dating, they impressively converge about the sequence of events. In each case, the discussion moves from west to east.

THE ROMAN OPTIMUM: STABILITY FROM C. IOO B.C. TO 200 A.D. Exceptional climate stability characterizes the centuries of the Roman Empire's rise; certain regions enjoyed unusually favorable conditions. In the western Roman Empire, the first century B.C. through the first and possibly second century A.D. were warmer than later centuries. Archaeological evidence from Britain, icecore data from Greenland, and dendrodata about summer temper- 
atures from Austria all agree on this score, as does the fact that the Alpine glaciers were retreating and, in the first and second century A.D., relatively small, comparable probably to their extent c. 2000 A.D. Two potential climate-forcing factors both show unusual stability. Within the generally even level of solar activity between C. 200 B.C. and 600 A.D., the centuries from 200 B.C. to IOO A.D. stand out as particularly stable (Figure Ia). An exceptionally low level of volcanic activity also prevailed from c. 4 O B.C. to I 50 A.D. (Figure 2b). In central Greenland, temperatures became warm from C. 20 B.C. to C. 75 A.D. A stable, relatively cool period followed from c. Ioo to C. 270 A.D. (Figure 2c). The speleothem in Austria's Spannagel Cave indicates stable conditions until about 250 A.D. (Figure Ib). Written sources from about 75 B.C. to C. I75 A.D. emphasize moisture (Figure 6a), predominantly in the form of the flooding of the Tiber River recorded at Rome. Precipitation in northeastern France was stable and largely balanced, fluctuating within narrow margins, also until about 250 A.D. (Figure 5 b). Quantitative palaeoclimate reconstructions deduced from pollen deposits in the Eifel maars (lakes formed from extinct volcanoes) also point to a stable climate pattern overall (Figures 3 and 4$){ }^{6}$

In detail, the chloride (Cl-) levels from Greenland indicate that sea ice retreated, implying that warming occurred between about I5 B.C. and 40 A.D. Cooling resumed with sea-ice expansion, peaking C. 70 A.D. before renewed warming in the last years of the first century (Figure 2a). The Greenland ice cores signal slow, slight cooling starting in the second century A.D. and continuing to about 270, implying longer winters in the North Atlantic (Figure 2c; cf. Figure II). The Austrian alpine dendrodata indicate that the warm summer temperatures c. 85 B.C. cooled until c. 35 B.C., followed by general warming interrupted by some cool years C. 20 A.D. and again between about 75 and 93, perhaps related to the Vesuvian eruption that destroyed Pompeii in 79 A.D. (Figure 5a). Nevertheless, the Alpine glaciers experienced a long retreat, and warm temperatures dominated in the Austrian Alps through the second century, punctuated by further cool spells

6 Ulrich E. Joerin et al., "Multicentury Glacier Fluctuations in the Swiss Alps during the Holocene," Holocene, XVI (2006), 697-704; Gregory S. Aldrete, Floods of the Tiber in Ancient Rome (Baltimore, 2007), I9-3 I; Büntgen et al., "2500," 578. 
Fig. 1 Solar Activity, Radiocarbon Production, and Speleothems

a.

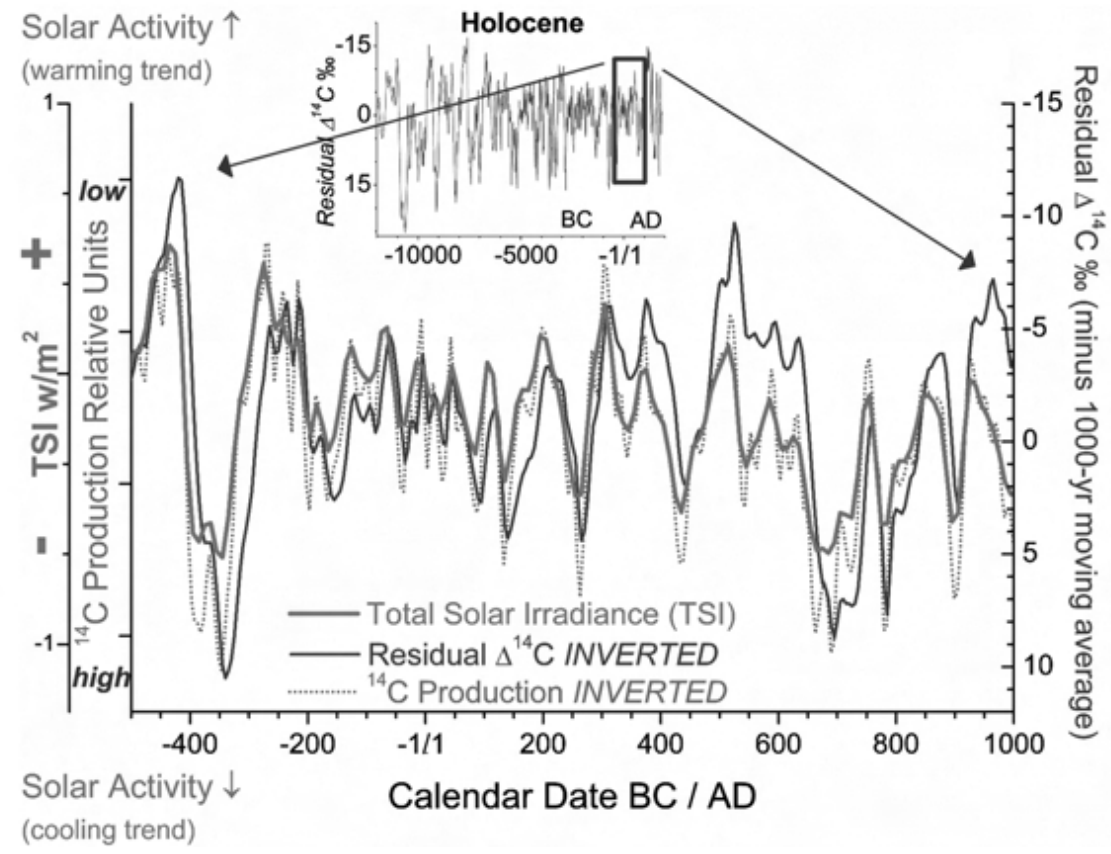

NOTE Changes in solar activity (Total Solar Irradiance [TSI]) can be reconstructed from variations in ${ }^{14} \mathrm{C}$ production. Increased ${ }^{14} \mathrm{C}$ production is associated with reduced solar activity and so generally cooler conditions on earth. For details, see Appendix (3).

b.

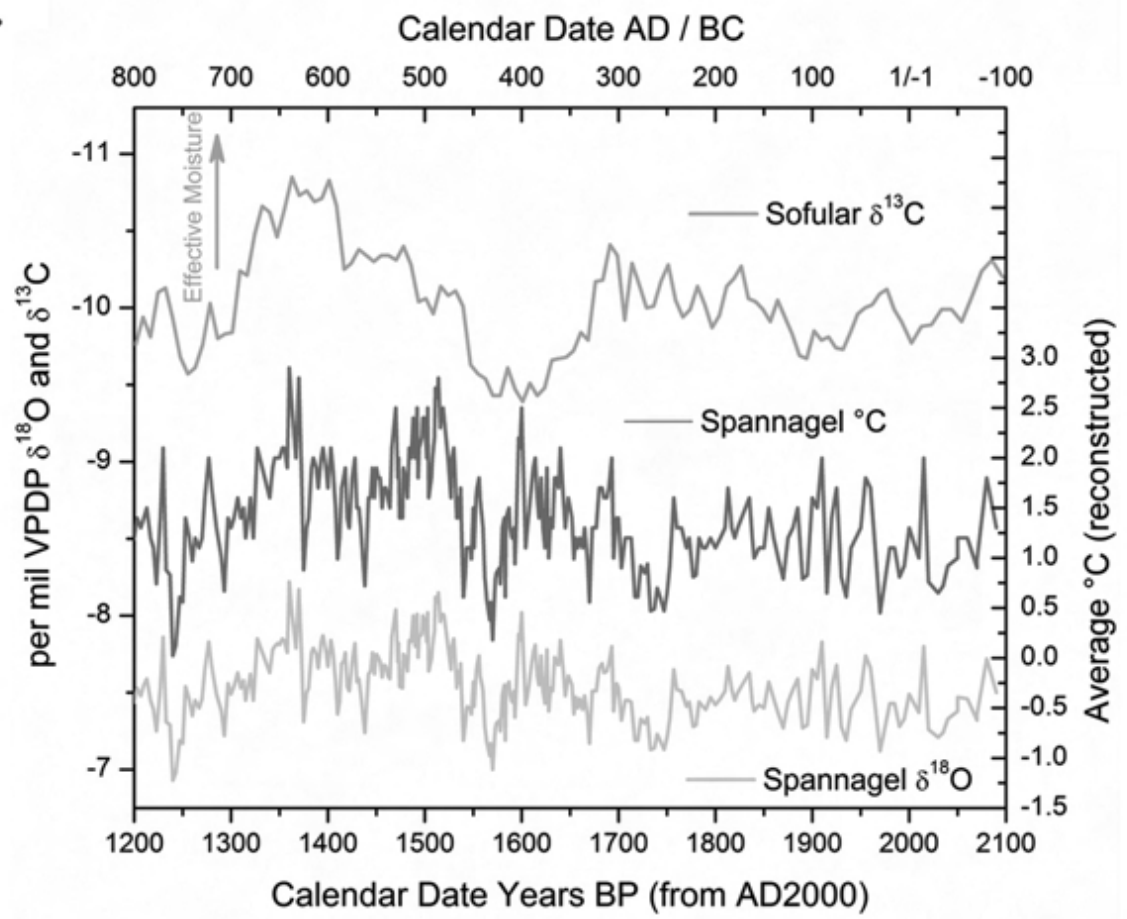

NOTE Speleothems (in this figure stalagmites). The Sofular Cave (Turkey, Asia Minor) $\delta^{13} \mathrm{C}$ record allows inferences of trends in humidity and/or temperature. The Spannagel Cave (Austria) $\delta^{18} \mathrm{O}$ record allows annual temperature reconstruction. See Appendix, 4. 
Fig. 2 Greenland Ice-Core Proxy Data for Sea Ice, Volcanism, and Annual Temperature (See Appendix [2] for Details)

a.

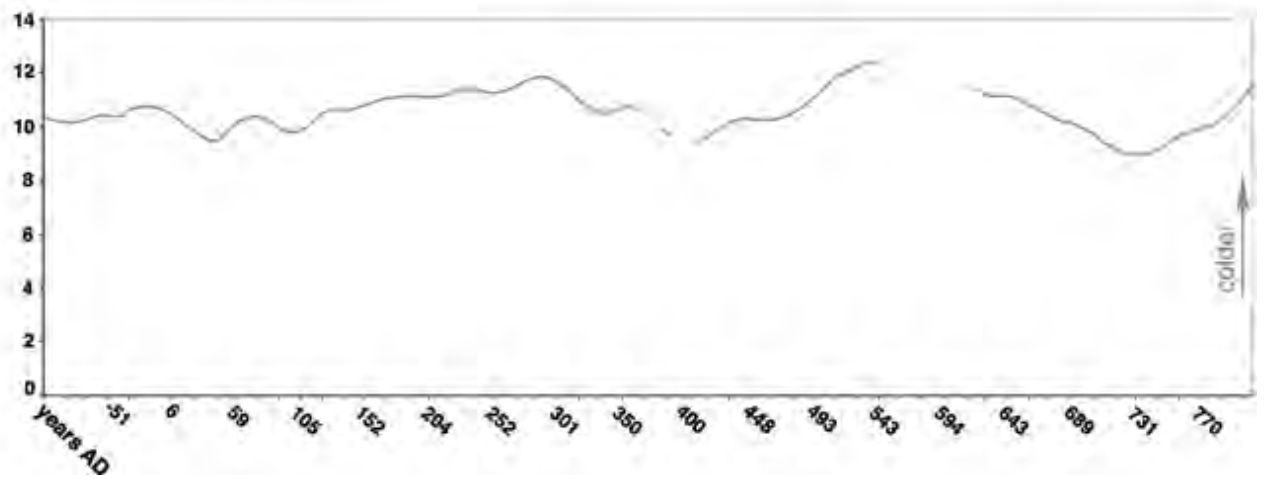

NOTE GISP2: Higher Cl- values indicate more extensive sea ice in the North Atlantic and generally cooler temperatures around Greenland; winter atmospheric circulation dominates. Lower Cl- values signal less sea ice, generally warmer temperatures; summer circulation dominates.

b.

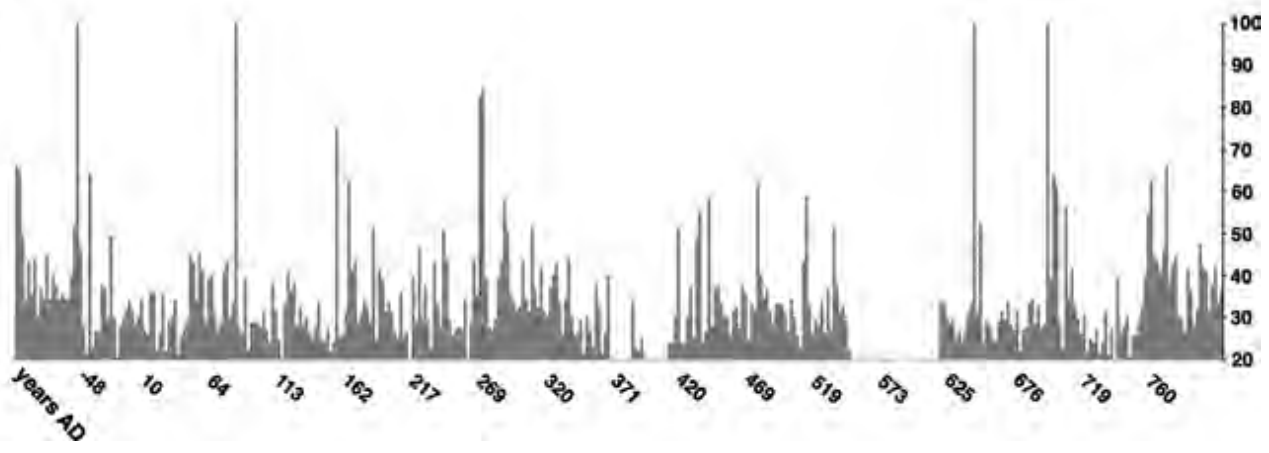

NOTE GISP2: $\mathrm{SO}_{4}$ peaks reflect violent volcanic eruptions that can temporarily lower global temperatures.

c.

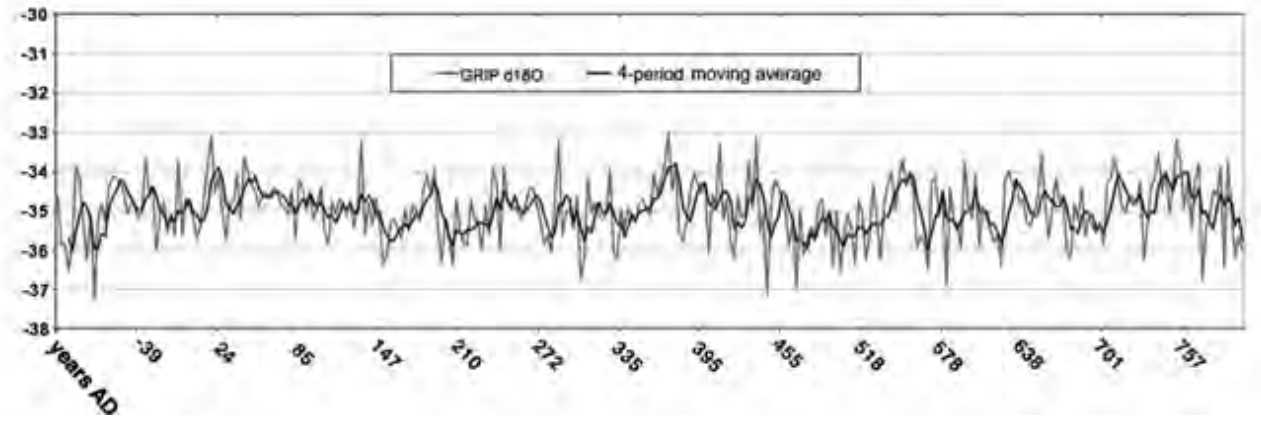

NOTE GRIP: $\delta^{18} \mathrm{O}$ proxy for temperature in Central Greenland, which usually has indicative value for the broader trend in the northern hemisphere. Lower values are colder. 


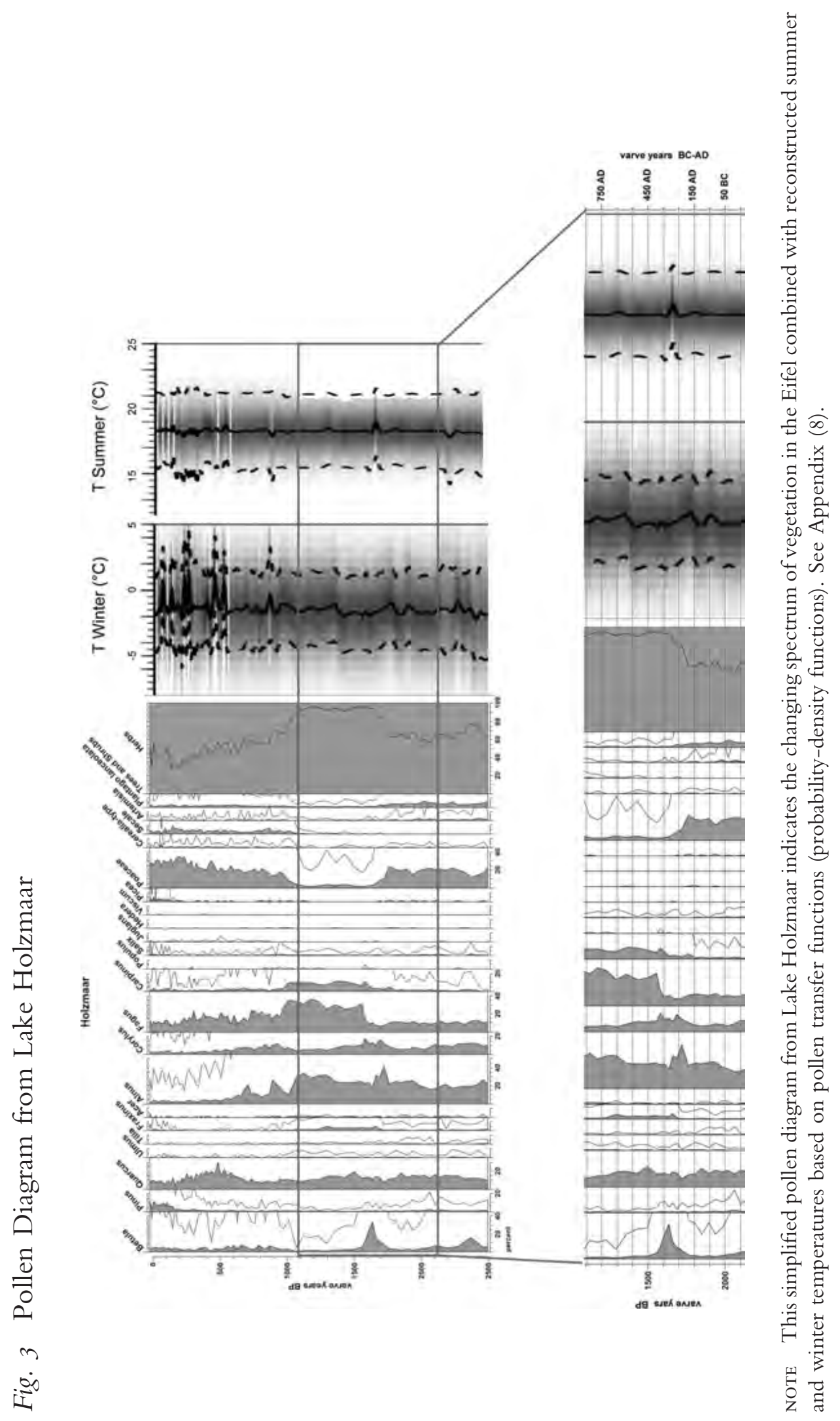




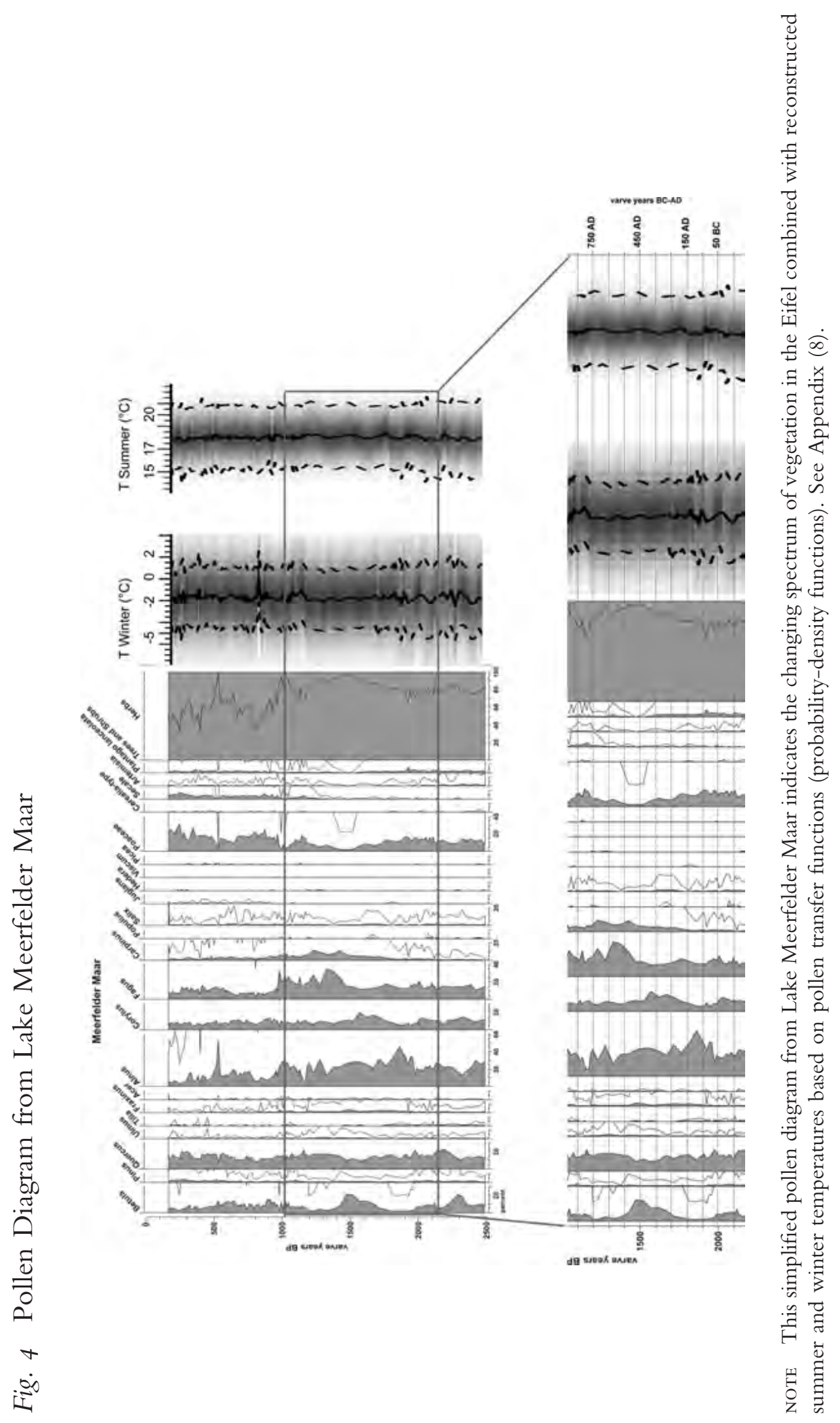


from c. I55 to I 80 and yielding to fluctuating temperatures trending toward cooler after about 200 A.D. (Figures $5 \mathrm{a}$ and I I). Volcanic activity with its risk of volcanic winters increased after I 50 A.D. (Figure 2b). Archaeological evidence of Roman viticulture in Britain also hints at warming in the early Empire. A strong indicator of warm temperature comes from archaeoentomological finds of the Nettlebug (Heterogaster urticae), which in Roman contexts occur far north of their I950s British habitats. The insect's documented biotopes suggest that during these centuries, mean July temperatures were at least $\mathrm{I}^{\circ} \mathrm{C}$ above mid-twentieth-century temperatures. The written evidence seems generally consonant with the proxy data (Figures $6 \mathrm{a}$ and $\mathrm{b}$ ). ${ }^{7}$

In the Levant, the Dead Sea levels clearly show two major peaks of wetter climate during the Roman Empire (Figure 7a). Although the sedimentary record and its radiocarbon dating lack the resolution available from ice cores or tree rings, the first, longer humid period appears to have lasted several centuries, coming to an end sometime c. 200 A.D. Lake Van isotopes indicate a shift away from higher aridity c. I 50 B.C. (Figure $7 \mathrm{~b}$ ). The Sofular speleothem shows relative stability from about IOO B.C. to about 250 A.D. (Figure $\mathrm{Ib}$ ). Isotope values in archaeological wood from the Roman siege ramp at Masada may also suggest wetter conditions around the Dead Sea in the first century A.D., which would agree with possible evidence from Ptolemy that Egyptian weather was rainier C. I20 A.D. than today. This finding is broadly consistent with the Greenland Ice Sheet Project 2 (GISP2) ice-core evidence for longer periods of winter-dominated circulation over Greenland from about Ioo to c. 300 A.D., which is associated with

7 A. G. Brown et al., "Roman Vineyards in Britain: Stratigraphic and Palynological Data from Wollaston in the Nene Valley, England," Antiquity, LXXV (200I), 706-757; Marijke van der Veen, "Food as Embodied Material Culture: Diversity and Change in Plant Food Consumption in Roman Britain," Journal of Roman Archaeology, XXI (2008), 83-I09; Harry Kenward, "Insect Remains from the Romano-British Ditch Terminal at the Flodden Hill Rectilinear Enclosure," in "Reports from the Environmental Archaeology Unit, York 200I/49" (200I), available at http://www.york.ac.uk/inst/chumpal/EAU-reps/eauo I-49. pdf. Future research should increase the archaeoentomological evidence, given the potential of ancient DNA detection of insect presence invisible to the eye in archaeological soil. See Philip Francis Thomsen et al., "Non-Destructive Sampling of Ancient Insect DNA," PLoS ONE, IV (2009), e5048. For details about the written evidence summarized in Figures 6a and $6 \mathrm{~b}$, see the relevant entries in McCormick, Harper, and More, "Geodatabase of Historical Evidence on Roman and Post-Roman Climate," in McCormick et al. (eds.), "Digital Atlas of Roman and Medieval Civilizations" at http://darmc.harvard.edu/. 
Fig. 5 Glaciers, Alpine Temperatures, and Precipitation Anomalies in Northeastern France

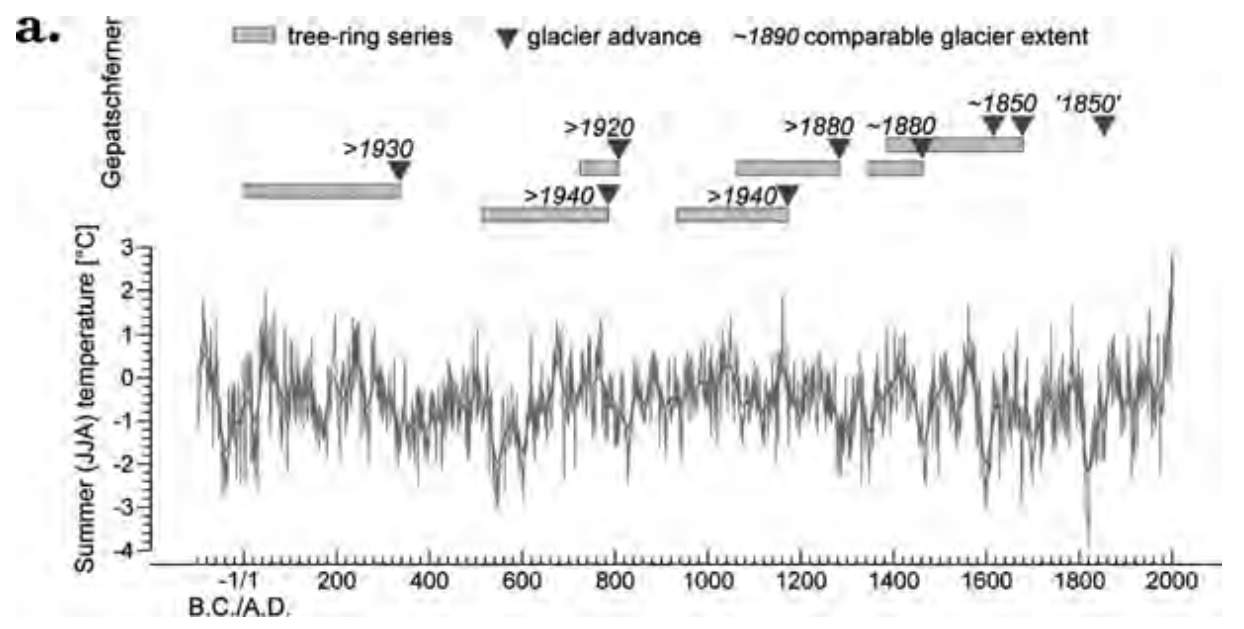

NOTE Gepatschferner Glacier (Austria): secure, dendrochronologically dated advances and comparable extents since I 850, compared to reconstructed Alpine summer temperatures. Advances reflect cooling and/or moisture (see Appendix [5] and [6]).

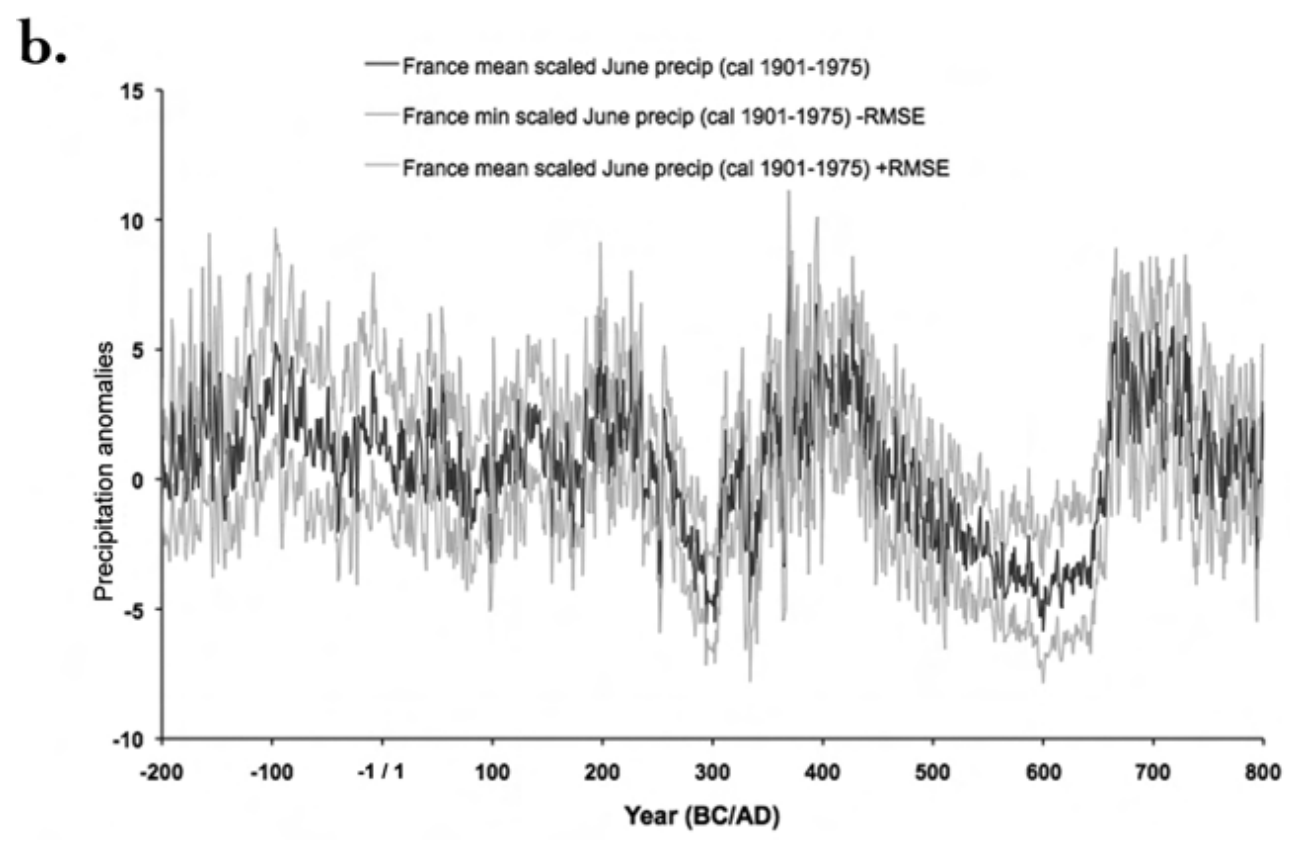

NOTE June precipitation anomalies in Northeastern France from tree rings, with error bars (see Appendix [7]). 
Fig. 6 Climate Events from Written Records, Ioo B.C.-800 A.D.: (a) Western Roman Empire and Successors; (b) Eastern Roman Empire and Successors

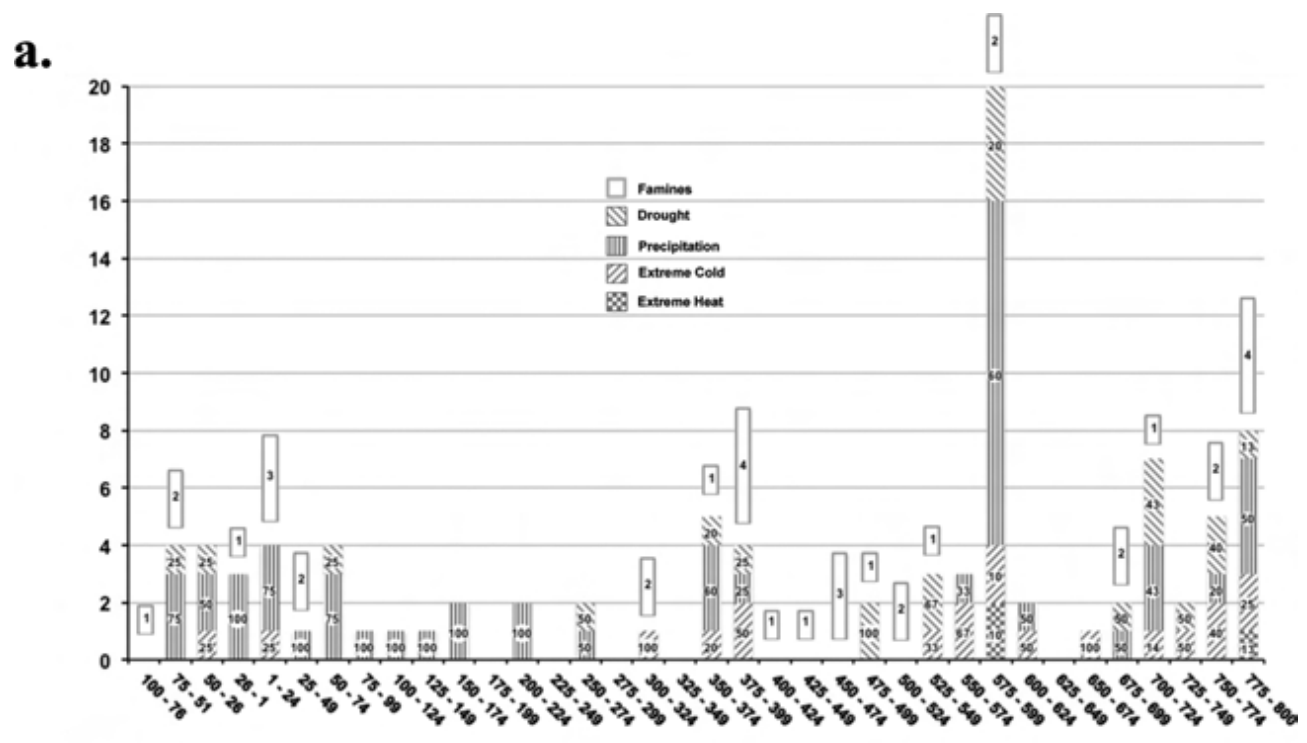

b.

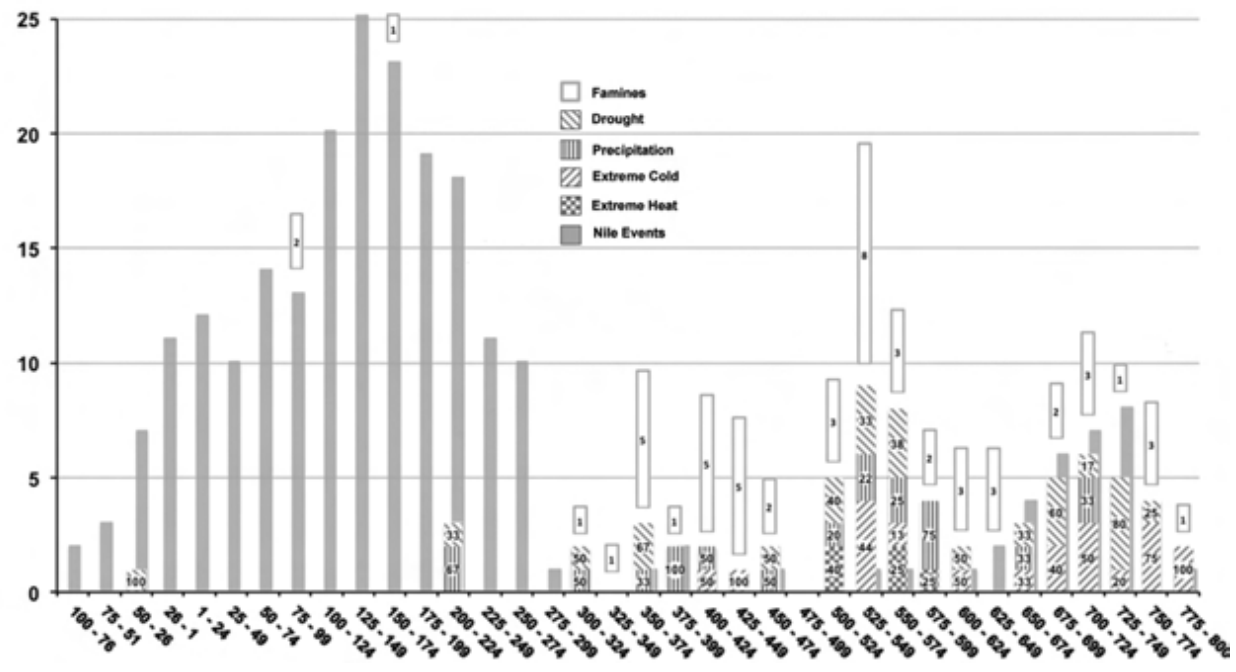

NOTE Figures $6 \mathrm{a}$ and $6 \mathrm{~b}$ are not to scale. Height of bars indicates number of events securely documented in each quarter century; shading and numbers within bars indicate percentage of each type of event report in that period; empty bars indicate separate counts of famines in that quarter century (See Appendix[I]). 
increased precipitation in the Middle East (Figure 2a; compare Figures $2 \mathrm{C}$ and I I) ${ }^{8}$

Finally, unnoticed until now, Egypt, the Roman Empire's breadbasket, appears to have enjoyed exceptionally favorable conditions for cereal production during this period. Nile river levels reflect precipitation over Ethiopia and East and Central Africa. Previous study has clarified the history of Nile floods down to 299 A.D., but that abundant evidence (Figure Io) has never been exploited for climate history or economic performance. Before Rome annexed Egypt, all seven of nine securely recorded Nile floods in the earlier years of the first century B.C. were below average. For the next 329 years, from the annexation in 30 B.C. to 299 A.D., reliable documents allow an estimate of the annual flood in I99 different years, after which the available data become scarce until 642 A.D. (see Appendix [I]). They show a subtle but significant pattern: The most favorable floods occurred more frequently between 30 B.C. and I 55 A.D., as clearly shown when contrasted with those of the following period (see below). ${ }^{9}$

8 Migowski et al., "Holocene Climate Variability and Cultural Evolution," 42 I-43 I. Lake Van shows a first shift away from aridity c. 2 IOO B.P. (before present)- that is, c. I 50 B.C. See L. Wick et al., "Evidence of Lateglacial and Holocene Climatic Change and Human Impact in Eastern Anatolia: High-Resolution Pollen, Charcoal, Isotopic and Geochemical Records from the Laminated Sediments of Lake Van, Turkey," Holocene, XIII (2003), 670. Arie S. Issar and Dan Yakir, "The Roman Period's Colder Climate: Isotopes from Wood Buried in the Roman Siege Ramp of Masada," Biblical Archaeologist, LX (I997), IOI-I06; S. Lev-Yadun et al., "Modeling the Demands for Wood by the Inhabitants of Masada and for the Roman Siege," Journal of Arid Environments, LXXIV (2010), 777-785, challenged the findings of wetter conditions, arguing from indirect evidence that the wood in question could have been imported to Masada from a more humid area. Ptolemy's weather calendar in his Phases of the Fixed Stars might indicate that Egypt was much wetter than today, if his reports of rain reflect real observations from one year (Ptolemy [ed. J. L. Heiberg], Opera Omnia [Leipzig, I907], II, I4-65). Lamb, Climate, History and the Modern World, I 59, and Konrat Ziegler, Realencyclopädie der classischen Altertumswissenschaft (Stuttgart, I959), XLVI, I8 I5-I8I6, think that they do report observations. Daryn Lehoux, Astronomy, Weather, and Calendars in the Ancient World: Parapegmata and Related Texts in Classical and Near Eastern Societies (New York, 2007), I I9, is skeptical; he prints and translates a number of ancient calendars with weather indications or predictions, the nature of which requires more thorough investigation.

9 Danielle Bonneau, La crue du Nil, divinité égyptienne, à travers mille ans d'histoire (332 av.641 ap. J.-C.) d'après les auteurs grecs et latins, et les documents des époques ptolémaïque, romaine et byzantine (Paris, 1964); eadem, Le fisc et le Nil; incidences des irrégularités de la crue du Nil sur la fiscalité foncière dans l'Égypte grecque et romaine (Paris, 197I); eadem, Le régime administratif de l'eau du Nil dans l'Égypte grecque, romaine et byzantine (Leyden, I993). Bonneau's findings are classified and tabulated in McCormick et al., "Geodatabase." For more detailed consideration of the evidence on Nile flooding, see McCormick, "What Climate Science, Ausonius, Nile Floods, Rye Farming, and Thatched Roofs Tell Us about the Environmental History of the Roman Empire," in Harris (ed.), Ancient Mediterranean Environment. 
Fig. 7 Lake Levels (Dates Radiocarbon Based and Therefore Approximate) and Volcanism

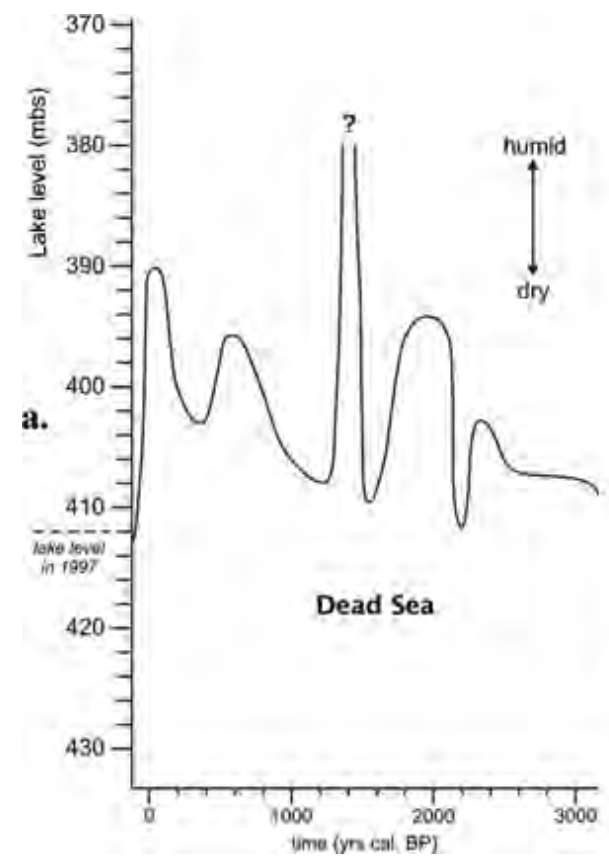

NOte Dead Sea: Fluctuating sea levels reflect overall precipitation in the Levant. Although the chronology is fluid, recent work clearly confirms earlier findings of an early and a late period of humid conditions, separated and followed by dry conditions (see Appendix [9]).

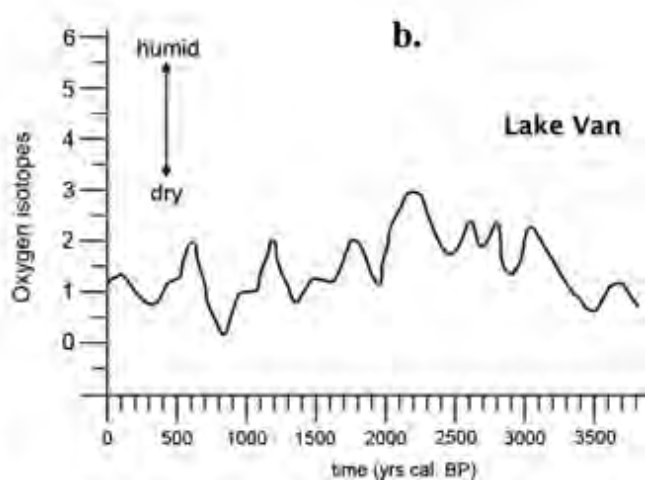

NOTE Lake Van: Oxygen isotopes within our period indicate most humid conditions $c$. the first centuries B.C. and A.D. and c. the fifth and sixth centuries A.D., and dry conditions c. the third and seventh centuries (see Appen$\operatorname{dix}[\mathrm{IO}])$.

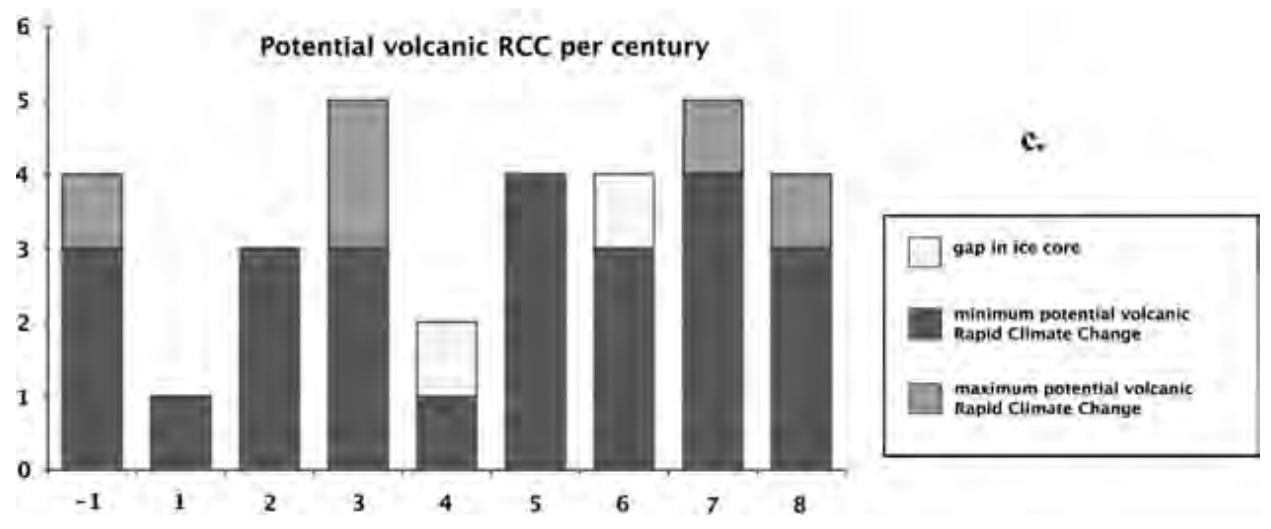

NOTE Potential volcanic rapid climate change: GISP2 $\mathrm{SO}_{4}$ deposits indicate that potential volcanic winters peaked during the third, fifth, and seventh centuries A.D. (see Appendix [2]). 
INSTABILITY AND INITIAL RECOVERY: 200 A.D. TO 400 A.D. From 200 to 400, the northwestern provinces of the Roman Empire overcame severe political, economic, and military crises, while the eastern and southern provinces continued their development more smoothly. Recovery ensued in the northwest and, despite severe barbarian pressure triggered by the Hunnic invasion, the eastern regions began their rise to political and economic dominance. The climate appears to have been less stable than in the preceding three centuries in both parts of the Empire, and multiproxy indicators are sometimes less consistent. Broader climate conditions seem to have impacted the eastern and western parts of the Empire differently.

Solar activity indicates a cooling episode about 260 A.D. (Figure ra). As noted, the Greenland ice cores show a slow increase of sea ice, and hence cooling, until c. 290 A.D. (Figure 2a). The $\delta^{18} \mathrm{O}$ (a measure of the ratio of stable isotopes of oxygen, ${ }^{18} \mathrm{O}:{ }^{16} \mathrm{O}$ ) ice-core proxy for temperature shows that central Greenland was cool, although it also began to warm C. 290 A.D. (Figure 2c). The cooling affected the northwestern provinces of the Empire, since the long retreat of the large and slow-reacting Great Aletsch glacier came to an end and the glacier was growing C. 272 A.D., when it reached an extent comparable to that c. I982 A.D. As noted, in the eastern Alps, the dendrodata indicate cooling beginning in c. 200; after a few warmer years from 22 I to 23 I and sharp cooling from 243 to 253 , gradual cooling prevailed until temperatures stabilized c. 3 I 5 and shifted to warming c. 365 (Figure 5a). This pattern is not inconsistent with the Spannagel speleothem record, although Spannagel suggests that the cooling ended a little earlier (Figure Ib). Precipitation in northeastern France and central Europe became exceptionally variable c. 250 until c. 650. The variability was initially accompanied by a marked trend toward dry conditions that peaked around 300 (see Figure $5 \mathrm{~b}$ ). ${ }^{10}$

Overall, the proxy data delineate a shift away from the stability of the first centuries toward a broadly cooling, drier climate as a background factor in the northwestern provinces' turbulent third century. The volcanic events of that period eventually gave way to a much calmer fourth century (notwithstanding the gap in the re-

Io Hanspeter Holzhauser et al., "Glacier and Lake-Level Variations in West-Central Europe over the Last 3500 Years," Holocene, XV (2005), 789-801. 
cord from 386 to 407 A.D.; see Figure 2 b). The three to five major volcanic eruptions that clustered from c. 235 to 285 potentially triggered commensurate episodes of rapid climate change (RCC), possibly reinforcing the solar forcing noted c. 260 (Table I; Figure 7c). Such rapid short-term changes would have had a great capacity to disrupt food production during the most difficult decades that the Roman Empire had faced so far; the political, military, and monetary crisis peaked between c. 250 and $290 .{ }^{11}$

Multiple proxies agree that warming occurred during the fourth century. The Greenland sea-ice proxy so indicates (Figure 2a). The isotope values show that central Greenland experienced stable temperatures or gentle warming through c. 375, punctuated by cool spells c. 305 and 335 (Figure 2c; Figure I I). The Austrian Alpine dendrodata suggest gradual cooling, but renewed warming started c. 365 (Figure 5a). The speleothem also indicates a warming trend in the second half of the fourth century (Figure $\mathrm{Ib}$ ). The dendrodating of in situ trees proves that the Gepatschferner Glacier advanced c. 335 , reaching an extent similar to that c. I930 A.D. (Figure 5a). But glacial growth stopped before 400; the definite retreat of the Lower Grindelwald by c. 400 appears to fit the warming signal from the Austrian dendrodata and speleothem. In Britain, the warmth-loving Nettlebug reappeared outside its main twentieth-century range in fourth-century deposits. Northeastern French and central European dendrodata indicate that dry conditions began yielding to relatively wet summers after 300 and that wet summers persisted from 350 until about 450 (Figure $5 \mathrm{~b}$ ), when conditions there were moister than they were under the early Roman Empire. The written sources shed relatively little light, but they also suggest more frequent flooding in the second half of the fourth century (Figure 6a). On balance, the proxy data point to a relatively stable fourth century that warmed during its second half, at least in the northwestern provinces of the Empire. ${ }^{12}$

I I On volcanism and the third century, see Rossignol and Durost, "Volcanisme global et variations climatiques," 424-429; for the crisis, Christian Witschel, "Re-evaluating the Roman West in the 3rd C. A.D.," Journal of Roman Archaeology, XVII (2004), 25I-28I.

I2 Nicolussi and Gernot Patzelt, "Untersuchungen zur holozänen Gletscherentwicklung von Pasterze und Gepatschferner (Ostalpen)," Zeitschrift für Gletscherkunde und Glazialgeologie, XXXVI (200I), I-87. However, trees germinating around 400 A.D. in the forefields of the Lower Grindelwald Glacier and the Suldenferner indicate that this advance ended in the second half of the fourth century. See Figure 2 in Holzhauser et al., "Glacier and Lake-Level Variations," 79I; Nicolussi et al., "Precisely Dated Glacier Fluctuations in the Alps over the Last Four Millennia," in Martin F. Price (ed.), Global Change in Mountain Regions (Duncow, 2006), 59-60. For Britain, see Harry K. Kenward, "Do Insect Remains from Historic-Period 
Table 1 Volcanic Activity and Climate Forcing from GISP2 and the Written Record (Figures $2 \mathrm{~b}$ and $7 \mathrm{c}$ )

\begin{tabular}{|c|c|c|}
\hline $\begin{array}{l}\text { YEARS B.C./A.D. } \\
\pm 2.5 . \text { GISP2 }\end{array}$ & $\mathrm{SO}_{4} \mathrm{RAW}($ (Рв) & $\begin{array}{l}\text { HISTORICAL EVIDENCE } \\
\text { FOR WINTERS } \\
\end{array}$ \\
\hline-98.9 & 65.42 & $\mathrm{O}$ \\
\hline-56 & 51.97 & $\mathrm{O}$ \\
\hline$-53 \cdot 9$ & 327.27 & $\mathrm{O}$ \\
\hline-44 & $64 \cdot 3 \mathrm{I}$ & harsh: 44/43 в.C. \\
\hline 77.2 & I $27 \cdot 37$ & $\mathrm{O}$ \\
\hline I $52 . \mathrm{I}$ & 74.93 & o \\
\hline I60.6 & 62.63 & $\mathrm{O}$ \\
\hline I 80.7 & 51.82 & $\mathrm{O}$ \\
\hline 236 & 5I.OI & $\mathrm{O}$ \\
\hline $264 . I$ & $82.7 \mathrm{I}$ & $\mathrm{O}$ \\
\hline 266.9 & $83.9 \mathrm{I}$ & $\mathrm{O}$ \\
\hline 282.4 & 58.12 & $\mathrm{O}$ \\
\hline 284.8 & 50.38 & 0 \\
\hline 303.8 & 51.68 & harsh: $303 / 34$ A.D. \\
\hline $4 \mathrm{I} 3 \cdot 3$ & $5 \mathrm{I} .54$ & 0 \\
\hline 429.7 & 55.28 & $\mathrm{O}$ \\
\hline 435.8 & 58.4 & harsh: 437/38 A.D. \\
\hline $47 \mathrm{I} \cdot 7$ & 62.01 & \\
\hline 507.7 & 58.98 & harsh? 505 A.D. \\
\hline 528.9 & 51.63 & harsh: $528 / 29$ A.D. \\
\hline 639.I & I 78.38 & 0 \\
\hline 643.2 & 52.64 & $\mathrm{O}$ \\
\hline 690.7 & I I 7.7 & 0 \\
\hline 694.5 & $64 \cdot 4$ & harsh: 698/89 A.D. \\
\hline 696.I & $6 \mathrm{I} .52$ & harsh: 698/99 A.D. \\
\hline $702 . \mathrm{I}$ & 56.38 & 0 \\
\hline 754.7 & $54 \cdot 7$ & harsh: $752 / 53$ A.D. \\
\hline 756.7 & 62.72 & harsh: $752 / 53$ A.D. \\
\hline 766.6 & 66.32 & harsh: 763/64 A.D. \\
\hline
\end{tabular}

NOTE $\mathrm{SO}_{4}$ peaks $(>5 \mathrm{Opb}$ ) come from GISP2 and recorded Roman winters: No written sources contradict the $\mathrm{SO}_{4}$ indicator of GISP2. "O" means that there is no known written evidence about that winter.

Archaeological Sites Track Climate Change in Northern England?" Environmental Archaeology, IX (2004), 47-59, esp. 49, Table I, in which four of the eleven Roman sites are dated to the fourth century, one to the "? $3^{\text {rd }}, 4^{\text {th }}$," and another is identified as fill-dated between the late third and late fourth. For French precipitation, see Büntgen et al., "2500 Years," 578. The suggestion of more frequent flooding in the second half of the fourth century may reflect, in part, the survival of Ammianus Marcellinus' history for these years: Res gestae I4, IO, 2 (354), I7, I2, 4 (358), 27, 5, 5 (368), 29, 6, I7 (374-375); see also Claudian, De bello Gildonico I, 4042 and Symmachus, Ep. 6, 7, I (397-398); further references in McCormick et al., "Geodatabase." 
With regard to the Empire's eastern provinces, the Talmud mentions droughts in Palestine most securely c. 2 IO to 220 , and, less compellingly, c. 220 to 240 and c. 255 to 270 ; multiple historical records document a general drought that lasted from c. 3 I I to 3 I 3 (Figure 6b). The Dead Sea levels show a sharp drop in precipitation C. 200 A.D. followed by a steep rise in precipitation lasting as long as 200 years, although radiocarbon dates for the return of wetter weather disagree. One study dates renewed moist conditions c. 300 A.D., which would fit archaeological features attributed to the fourth century that show a substantial rise in the Dead Sea shoreline; springs in Roman Palestine may also have been more productive then. Another investigation places the return of wetter weather C. 400 A.D., which would be consistent with the Greenland Cl- values that reflect longer summers and thus less precipitation in the Middle East until about 400 (Figure $7 \mathrm{a}$ ). ${ }^{13}$

Although the numbers are small, the proportion of historical records of drought to those of high precipitation favors precipitation between 375 and 475 (Figure 6b). The Sofular-cave record also indicates a drying and/or cooling period in Asia Minor followed by a prolonged wetter and/or warmer era, although the dates assigned to both periods run a little later than those derived from the other proxies (Figure $\mathrm{Ib}$ ). Future work will have to clarify whether wetter conditions returned to the eastern Roman Empire closer to 300 or to 400. In either case, the eastern Roman Empire's prosperous fifth century coincided with increased moisture, precisely the most critical variable in its relatively arid environment. ${ }^{14}$

Two major climatic developments originating beyond Rome's frontiers that played an important role during this period have attracted little or no scholarly attention. As noted, the annual floods of the Nile, which reflect precipitation in Central and East Africa, seem to have undergone a subtle but significant change in

I 3 For references to the written sources, see McCormick et al., "Geodatabase," under these years. Bookman (Ken-Tor) et al., "Late Holocene Lake Levels of the Dead Sea," 555-57I; Hirschfeld, "Climatic Change in the Early Byzantine Period?" I33-I49; Migowski et al., "Holocene Climate Variability and Cultural Evolution," 425 (Figure 3).

I4 Among the most securely attested events is one report each of flooding and drought from 300 to 350 . From 375 to 475 , one or two droughts and four precipitation/flooding events are mentioned in the eastern Empire. See McCormick et al., "Geodatabase," for details. The Sofular Cave records indicate drying and/or cooling from c. 300-450 A.D., followed by wetter/warmer from c. 450-625 A.D. 
the second century A.D. Until 299 A.D. (when the data become sparse), the overall proportion of good to average floods compared to that of floods ranging from poor to bad appears identical on either side of I55 A.D. (see Figure I0). However, closer scrutiny reveals that the early Roman Empire enjoyed substantially more abundant and therefore agriculturally beneficial floods than did the later Roman Empire, at least until 299 A.D. Before I 55 A.D., 20 percent of floods were of the two most favorable categories, whereas only 8 percent fit that description after I 55. Conversely, the three most serious categories of deficient floods occurred more frequently during the later period (3 I percent) than during the earlier Empire (2 I percent). In other words, when the Empire was at its zenith, and the great grain fleets sailed north every year to feed the capital and swell the cereal resources of the Empire, Egypt's productive farms seem to have enjoyed better Nile floods and therefore better harvests and fewer failed harvests. ${ }^{15}$

After I 55 A.D., when the Empire struggled to face mounting political, military, and economic challenges, the best harvests became substantially more infrequent and the worse ones more common. The written records suggest that unusually favorable climate conditions for Egyptian food production prevailed throughout the first two centuries of the Roman Empire, whereas the conditions underpinning food production appear to have been consistently less good from I 55 to 299 A.D. This new observation will require detailed scrutiny from the vantage point both of the written evidence and whatever proxy data and potential climate mechanisms can be developed, since a changing food supply for the great cities and armies of Rome holds considerable explanatory power. ${ }^{16}$

After a generation of optimistic revisionism that downplayed the importance of invasions, historians in the last decade have increasingly restored barbarian movement to a prominent role in a

I5 The overall proportions from 30 B.C. to I 55 A.D. are $64.3 \%$ good to average floods vs. $35.7 \%$ poor to bad ones ( $N=$ II 2 ); from I55 to 299 A.D., $64.4 \%$ vs. $35.6 \%$, respectively $(N=87)$. See also for the Nile flood records during this period, McCormick, "Climate Science, Ausonius, Nile Floods."

I6 So far, Nile flood records are easily available or deducible for only seven years of the next three centuries when the Romans retained full control of Egypt (300-6I 8 A.D.). See McCormick et al., "Geodatabase." Reconstructing from the late Roman papyri the kind of Nile flood record that has been developed for the earlier centuries should be an urgent priority. The advantage of the early Roman Empire's Nile floods might have been even greater, but this article classifies and counts the floods conservatively. 
more catastrophic interpretation of late Roman history. Historians and archaeologists have long debated whether climatic conditions had anything to do with the migration of non-Roman groups into the Empire. Far beyond the Roman frontiers, Central Asia notoriously produced nomadic groups whose expansion impinged on Eurasia's sedentary empires. The pastoral component of their economy likely made them sensitive to fluctuating patterns of precipitation, just as the Romans explicitly observed of Arab pastoralists in the Persian Empire. New dendrodata indicate that from c. 50 A.D. onward, wetter and drier periods than average alternated in Central Asia, changing to average or wetter-than-average years in the second century (Figure $8 \mathrm{a}$ ), without any noticeable effect on the western Empires. The first half of the third century was wetter than average, and the second half was marked by drought conditions from about 242 to 293, with intermittent returns to more normal conditions. ${ }^{17}$

But the crucial development was the severe drought of the fourth century that lasted nearly forty years, one of the worst in 2000 years. Documented by the Dulan-Wulan tree-ring chronology, prevailing drought conditions began in 338 A.D. and continued until 377, when wetter conditions returned (Figure 8b). The El Niño-Southern Oscillation (ENSO) Pacific Ocean climate pattern is a candidate as a broader climate system cause (Figure $9 \mathrm{a}-\mathrm{c}$ ). Both the Douglas Fir data from New Mexico and the kauri data from New Zealand are sensitive to tropical Pacific ENSO forcing, the most geographically pervasive mode of climate forcing on earth. The extent of this drought in time and space suggests that it played a critical role in driving the mobile pastoral federation that coalesced around the name of "Huns" somewhere east of the Don River, to seek pastures and predation farther to the west and south (Figures $8 \mathrm{~b}$ and $9 \mathrm{c}$ ). The dendrodata confirm speculation about an environmental factor in the Hunnic invasion that goes back at least a century. Historical sources indicate that the Huns reached the Don River by the 370 and crossed it c. 375. Their attacks in the area north of the Black Sea drove the Goths to flee into the Roman Empire and ultimately to attack it, destroying an emperor and

I7 Peter J. Heather, The Fall of the Roman Empire: A New History of Rome and the Barbarians (New York, 2006); Marcellinus Comes (ed. Theodor Mommsen, Monumenta Germaniae Historica, Auctores Antiquissimi, XI), Chronicon, Auctarium a. 536 (Berlin, I894), I05. 
his army in 378 at Adrianople (now Idirne, Turkey), one of the greatest military defeats in Roman history. ${ }^{18}$

INSTABILITY RETURNS: 400 A.D. TO 600 A.D. The collapse of Roman political and economic structures in the western provinces during this period gave rise to new, mixed barbarian-Roman polities. Meanwhile, the eastern half of the Roman Empire experienced stability and growth sufficient to enable it to reconquer several western provinces, until it confronted a series of epidemics and other crises that began c. 540 .

Solar activity indicates a cooling episode in the middle of the fifth century (Figure ra). Greenland sea ice also indicates a fifthcentury cooling that peaked c. 540 (Figure 2a). In central Greenland, the distinctly cooler 380 s yielded to a warming trend that ended with a sharp temperature plunge c. 405, followed by fluctuating temperatures until about 630 . Temperatures there, however, were somewhat more stable between c. 480 and 520, and again between c. 540 and 560, when the Greenland Ice Core Project (GRIP) data show them to have been warmer. Sudden cooling occurred around 526 and 535, and again c. 585 (Figure 2c).

So far, Alpine glaciers do not provide clear signals for the western provinces during the fifth century after the traces of glacial retreat-and therefore warming-already noted for C. 400 A.D.

I 8 P. R. Sheppard et al., "Annual Precipitation since 5I5 BC Reconstructed from Living and Fossil Juniper Growth of Northeastern Qinghai Province, China," Climate Dynamics, XXIII (2004), 869-88 I (see also Appendix [I I] herein). For the New Mexico data, see Henry F. Diaz and Vera Markgraf, El Niño and the Southern Oscillation: Multiscale Variability and Global and Regional Impacts (New York, 200o); for New Zealand, Anthony M. Fowler et al., "ENSO History Recorded in Agathis Australis (Kauri) Tree Rings: Part A: Kauri's Potential as an ENSO Proxy," International Journal of Climatology, XXVIII (2008), I-20; idem, "ENSO History Recorded in Agathis Australis (Kauri) Tree Rings: Part B: 423 Years of ENSO Robustness," ibid., 2I-35. A combined ENSO index based on the New Mexico Douglas fir and New Zealand kauri chronologies indicates severe and persistent La Niña-like conditions from 36I to 406 A.D., from 438 to 457 , and from 554 to 568 .

Ellsworth Huntington, The Pulse of Asia: A Journey in Central Asia Illustrating the Geographic Basis of History (Boston, I907), 329-385, argued for a drought-induced migration chiefly from what he took to be archaeological evidence of the fluctuation of Caspian Sea levels. See Lamb, Climate, History and the Modern World, I59-I60. For a judicious summary of the controverted early history of the Huns and further references, see Walter Pohl, "Huns," in Glen W. Bowersock et al., Late Antiquity: A Guide to the Postclassical World (Cambridge, Mass., I999), 50 I-502; Otto Maenchen-Helfen, The World of the Huns: Studies in Their History and Culture (Berkeley, I973), I-36; Arnold H. M. Jones, The Later Roman Empire, 284-602: A Social, Economic, and Administrative Survey (New York, 1964), I, I52-I54. 
Fig. 8 Precipitation and Drought, Central China

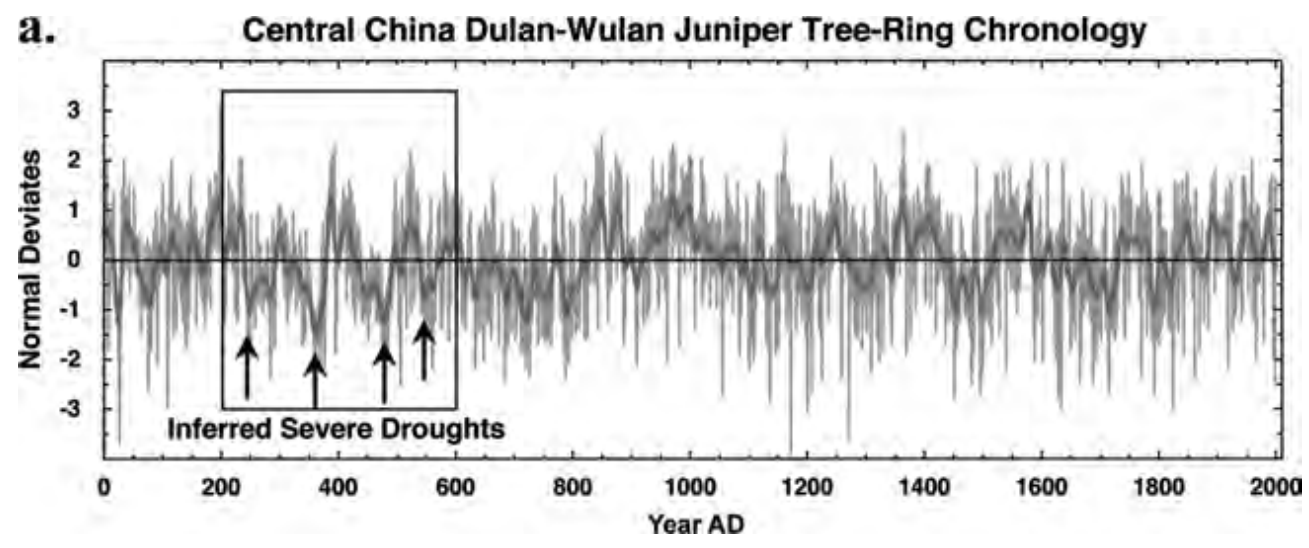

NOTE Juniper tree-ring chronology from Central China, showing periods of inferred extreme drought. The drought from 338 to 377 A.D. was one of the worst in 2,000 years (See Appendix [I I]).

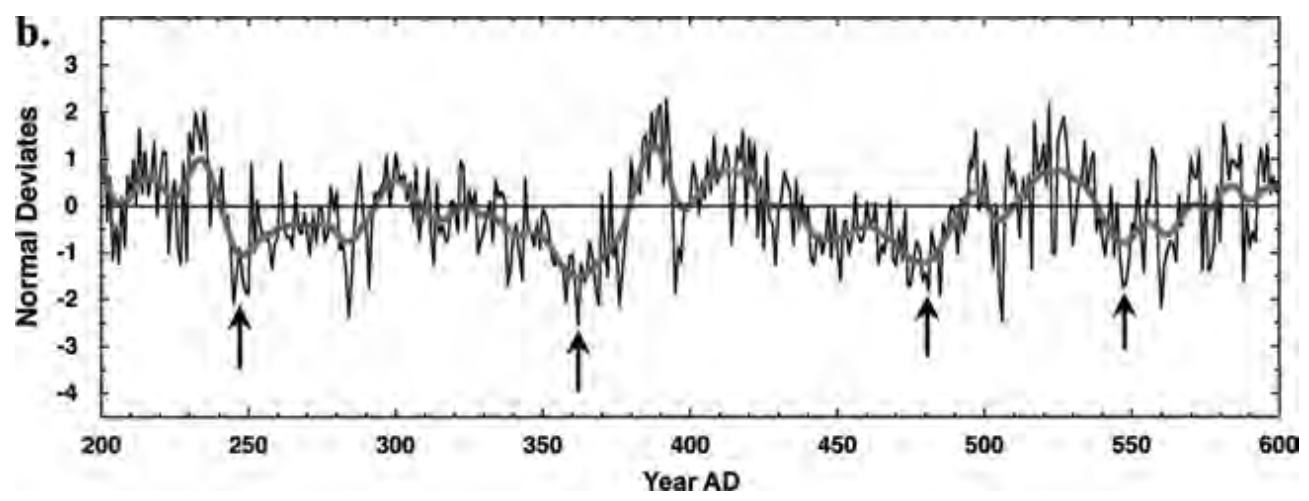

NOTE Tree rings as above, detail of 200-600 A.D.

Around 430, the slow-reacting Great Aletsch was still advancing. However, the fact that an in situ tree growing in the forefield of the Suldenferner glacier survived for more than 400 years (c. 409 to 836 A.D.) without being uprooted by the advancing glacier suggests that the Suldenferner glacier was smaller then than it would become in the ninth century and that the glaciers in the eastern Alps did not approach their Little Ice Age maximum extent in the sixth century A.D. The evidence from tree rings does not contradict these indications. It indicates that the Alpine summer temperature was neither especially warm nor cool in the fifth century, although it may have risen slightly as the century progressed (Figure 5a). The Austrian speleothem indicates cooling during the first 
Fig. 9 Tree Rings from New Mexico and New Zealand, Enso Index, and Correlation with December to May precipitation (See Appendix [I I])

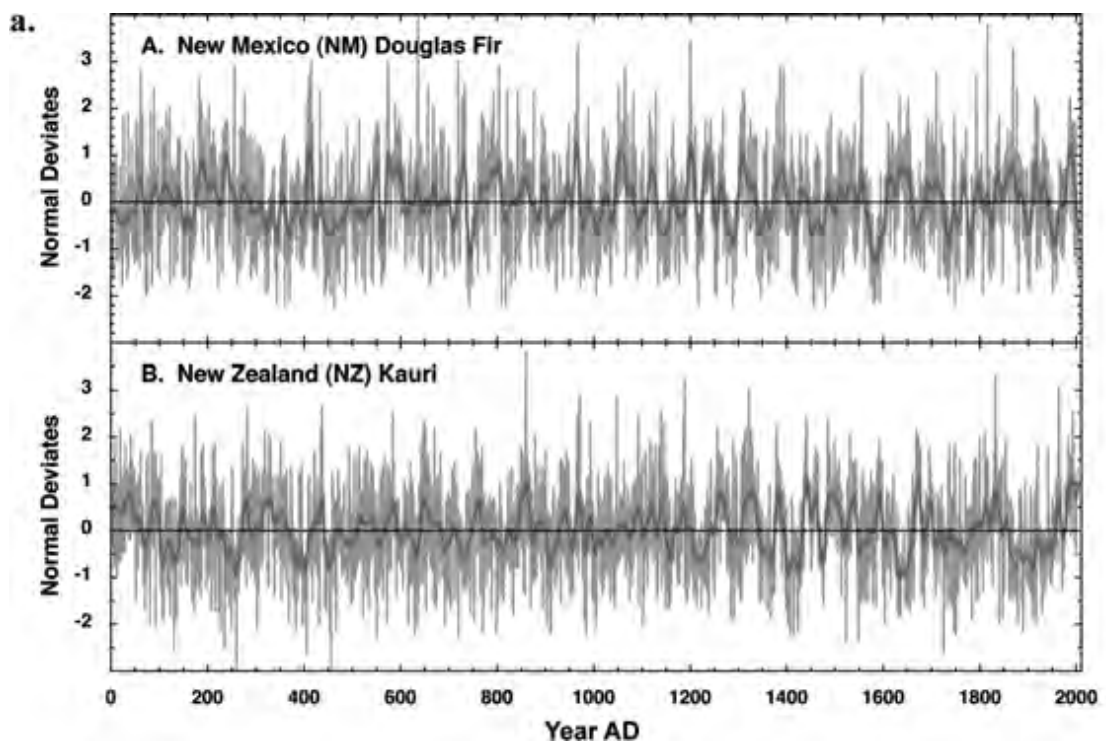

nOte Tree-ring chronology from Douglas Fir in New Mexico and Kauri in New Zealand.

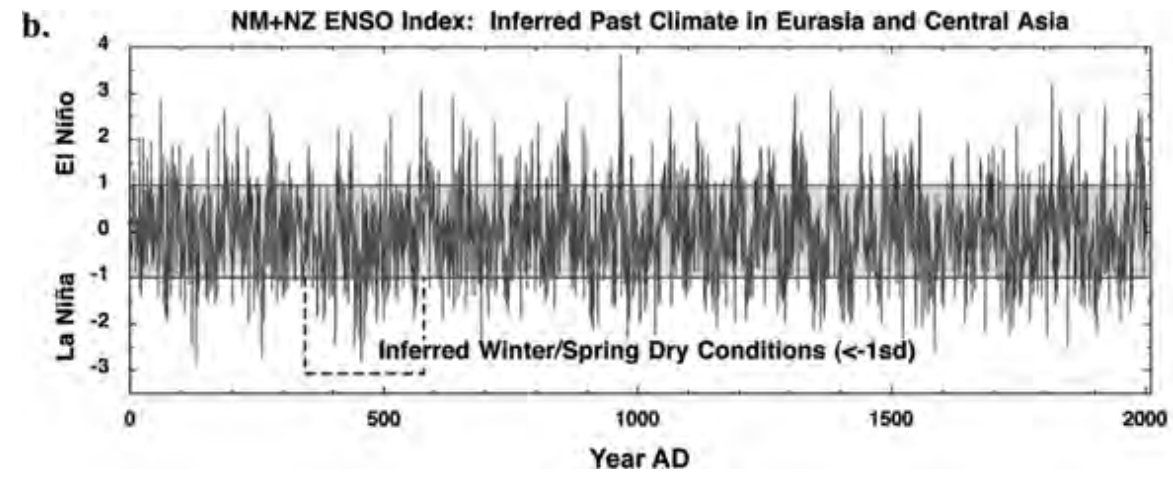

Note New Mexico and New Zealand Enso Index-inferred past climate in Eurasia and Central Asia. The ENSO Index suggests that the droughts recorded by tree-ring chronology in Central China may reflect tropical Pacific ENSO forcing.

c.

Dec-May Precipitation Correlations with NM+NZ ENSO Index

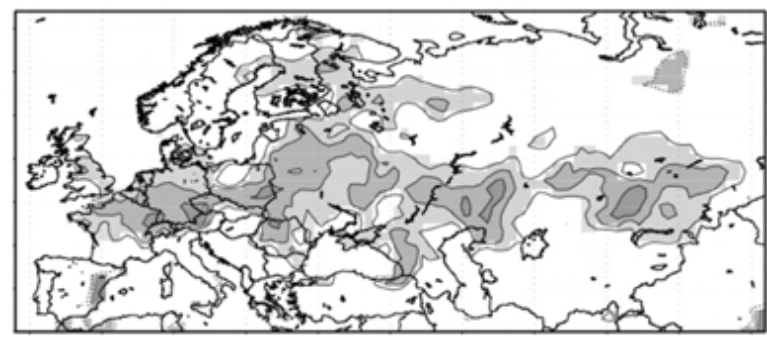

NOTE December to May Eurasian precipitation correlations with the New Mexico and New Zealand ENSO Index. 


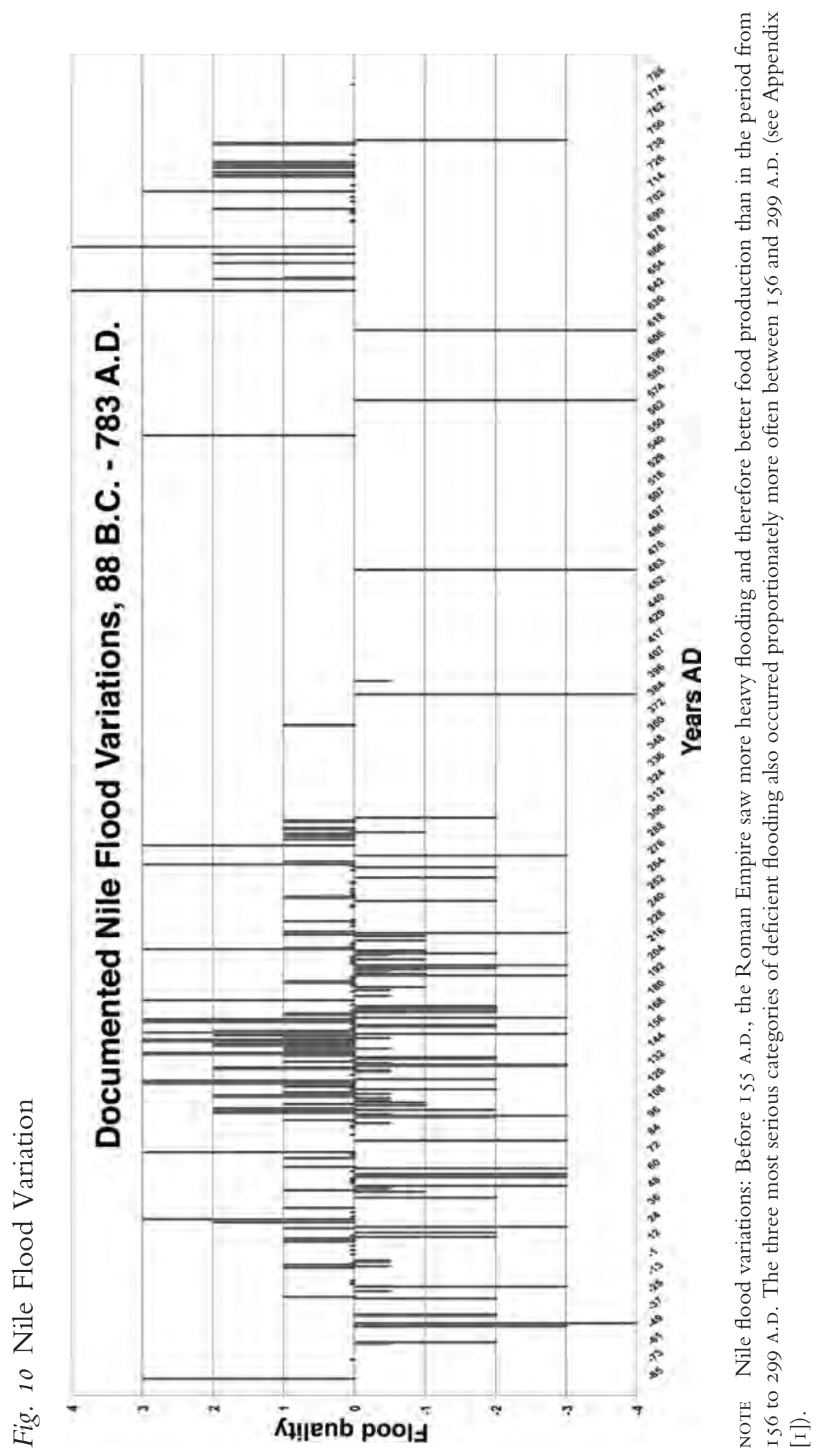


half of the century, followed by a similar warming during the second half of the fifth century (Figure $\mathrm{Ib}$ ). ${ }^{19}$

Two potentially important factors for climate instability recur in the fifth century. Even with a gap in the Greenland Ice Sheet Project 2 (GISP2) record from c. 386 to 407 ( \pm 2.5 years), there is evidence that the fifth century was almost as volcanically active as the third, implying a considerable likelihood for disruptive volcanic winters regardless of the overall temperature trend (Figures $2 \mathrm{~b}$ and $7 \mathrm{c}$; see also above, Table I). In northeast France, summer precipitation was extremely wet until about 450 when general conditions again shifted to extremely dry. They prevailed for the next two centuries (Figure $5 \mathrm{~b}$ ).

Written sources from the entire Empire document the seriousness of the veiling of solar radiation in 536 and 537, which caused crop failures in different areas. Moreover, many northern European tree rings reveal severe stress during these years, and the solar veiling has been connected with a powerful volcanic eruption. As noted, and consonant with the solar veiling, the Greenland sea-ice evidence for cooling peaks c. 540 (Figure 2a). In the Alps, the tree rings are symptomatic of relative warming toward 5 IO, followed by cooling c. 540 (Figure 5a). Congruent with most of these indications is the strong glacier advance known to have occurred in the Swiss Alps during the sixth century, although it probably was not as strong as some have thought. Thanks to new dendrodates for previously published samples, we now know that the Lower Grindelwald Glacier (Swiss Alps) advanced around the mid-sixth century. The Zmutt Glacier (Swiss Alps) also was advancing. Overall, the sixth century looks to have been cooler in the post-Roman west. ${ }^{20}$

I9 Holzhauser et al., "Glacier and Lake-Level Variations." The tree growing in the forefield of the Suldenferner glacier was some meters beyond the I920 A.D. moraine. See Nicolussi et al., "Precisely Dated Glacier Fluctuations," and, for details, Nicolussi and Johann Stötter, "Zur Geschichte der Gletscher der nördlichen Ortlergruppe im I9. und 20. Jh.," Iо, available at http://www.uibk.ac.at/geographie/forschung/dendro/publikationen---pdf-files/ nic_stoett_ortler_schlern_draft-Ib.pdf.

20 Gunn (ed.), Years without Summer; Arjava, "Mystery Cloud of $536 \mathrm{CE}$ in the Mediterranean Sources"; Larsen et al., "New Ice Core Evidence for a Volcanic Cause." The GISP2 $\mathrm{SO}_{4}$ record has a gap approximately between 54I and 6I 3 A.D. but shows no major eruption in the years preceding the gap. Holzhauser et al., "Glacier and Lake-Level Variations," suggest that the Aletsch glacier advanced at least to nearly Little Ice Age maximum extensions around 600 A.D. However, this suggestion is not supported by recent results from the eastern Alps. Detrital wood from the forefield of the Gepatschferner glacier, which covers the entire period be- 
Against the backdrop of overall conditions that c. 450 had become drier in northeastern France (Figure 5b) and central Europe, historical records document serious floods and hence a relatively wet final quarter of the sixth century in Italy and Gaul (Figure 6a). The written sources generally also corroborate here the new annual record of early summer precipitation recently established from tree rings of northeastern France. ${ }^{21}$

tween c. 5 IO and 809 A.D., suggests that this glacier's sixth-century advance did not exceed glacier limits of about A.D. I920/I940. The in situ tree that grew from the early fourth to the ninth century A.D. at a position in the forefield of the Suldenferner proves that the glaciers in the eastern Alps did not advance in the sixth century nearly to a Little Ice Age maximum extent. Terminal tree rings between c. 546 and 579 A.D. now clarify the chronology of the Lower Grindelwald in Holzhauser's previously published materials; compare Holzhauser and Heinz J. Zumbühl, "To the History of the Lower Grindelwald Glacier during the Last 2800 Years-Paleosols, Fossil Wood and Historical Pictorial Records-New Results," Zeitschrift fur Geomorphologie Supplementband (1996), 95-I27. F. Röthlisberger, "Gletscher- und Klimaschwankungen im Raum Zermatt, Ferpècle und Arolla," Die Alpen [Special issue: "80oo Jahre Walliser Gletschergeschichte"], LII (I976), 89, investigated and ${ }^{14} \mathrm{C}$-dated a $\log$ found in the forefield of the Zmutt Glacier (Swiss Alps), at a position comparable to the ice extent c. I920 A.D.

2I Written sources document a powerful flood that swept down the Rhone in 563 , carrying away small riverside settlements, destroying the bridge and watermills at Geneva, and flooding the town; the new precipitation index for central Europe shows that the precipitation in northeastern France during the spring of that year was heavy. For detailed references to events cited in this note and known from the written sources, see McCormick et al., "Geodatabase," under the relevant year. For the dendroecological data, see Büntgen et al., "2500 Years," Figure $\mathrm{S}_{4}$, available at http://www.ncdc.noaa.gov/paleo/pubs/buentgen2o I / buentgen2o I . $\mathrm{html}$, from which all other dendrodata cited in this note come. The year 580 witnessed severe flooding in the Loire and Rhone systems, as well as in Italy. As Marius of Avenches makes clear, this flooding occurred in autumn, and, hence, unsurprisingly, left no trace in the spring precipitation record from northeastern France. In discussing an event of January 583, Gregory of Tours mentions for western and central France high water levels on the Loire and flooding of the Seine at Paris; northeastern France experienced positive spring precipitation. Great floods affected, apparently, the Loire basin and Burgundy, in the spring of 585; Rome also experienced unparalleled flooding. The dendrodata also show a wet spring in Central Europe and northeastern France. In the spring and autumn of 587, heavy rains, snow, and more rain caused flooding in France, confirmed by the dendrodata for Central Europe. The spring of 589 was extraordinarily wet around Tours, and flooding continued or recurred apparently in the autumn. AmJ precipitation was below normal in northeastern France but well above normal in Bavaria and Brandenburg. Gregory of Tours mentions heavy rains in France in 590 apparently during the autumn, when extreme AMJ precipitation fell in northeastern France and Bavaria, and below normal precipitation fell in Brandenburg according to the dendrodata. The next year seems to have begun with a terrible spring drought, followed by later summer flooding that destroyed the mowed hay; a severe AMJ drought is documented by the dendrodata. Finally, Gregory (ed. B. Krusch and W. Levison in Monumenta Germaniae Historica, Scriptores rerum Merovingicarum, I), Historiarum libri X, 5, 4I (I937), 248, obliquely refers to water that was even higher. The way in which he expresses the point could indicate that the text would be more accurately attributed to the year $58 \mathrm{I}$ than to the editor's suggested 580 (see, however, ibid., 248, n. 4); AMJ of 58I were less wet than usual in northeastern France. 
In seeming contrast to broader dry conditions in France, the increase in eastern precipitation and generally humid conditions in the eastern Roman Empire resumed or continued as those provinces reached their political and cultural apogee. The longer winters in Greenland from roughly 400 to 540 are consistent with increased precipitation in the Levant. As noted, Dead Sea levels testify to a steep increase in precipitation that lasted about two centuries and started either c. 300 or 400 . The eastern written records from c. 375 to 475 concur, insofar as precipitation events outpaced drought reports, though these conditions were to change dramatically c. 500 .

In the early sixth century, in addition to reports of sharp cooling and crop failures at the time of the 536 event, mentions of eastern droughts and heat events exceed those about precipitation; some of these droughts are of great severity, notably the long one that affected Palestine from 523 to 538 , when even normally reliable springs dried up (Figure 6b). Contemporaries explicitly connect a 536 drought with the migration of Arab pastoralists into the Empire. Roman water works in Palestine appear to have been inordinately concentrated in this period. The summer water shortages that affected Constantinople during the 520 s could also reflect a decline in precipitation compared to that in the fourth and fifth centuries when the capital's great aqueducts had been constructed. More decisively, the two centuries of favorably wet Levantine conditions documented by Dead Sea levels came to an end at some point in the sixth century and, according to both key studies, dry conditions persisted through the eighth century. ${ }^{22}$

22 Written sources reliably document fourteen drought and heat events in the eastern Roman Empire between 500 and 599 A.D.: In Palestine, c. 500, drought destroyed valuable vineyards in the Negev; a fifteen-year drought from 523 to 538 dried up the Siloah spring; winter heat events occurred in Cilicia in 550 and in Palestine and Syria in 600/or; droughts struck Syria in 525/26 and 568/69, and the Persian Empire in 536, provoking the Arab migration; Constantinople suffered droughts in 530 (autumn), 556, and 562, and an exceptional heat spell from approximately September to November 55I; heat events occurred in Mesopotamia in 501, 502, and 595; and Cilicia underwent a spring heat event that melted snow and caused flooding in 550. See McCormick et al., "Geodatabase," for detailed records. Eight excessive precipitation events and/or floods are recorded with similar levels of certainty for Mesopotamia in 501/02, 525 (including Syria), 553/54, 580, from approximately 582 to 602 , and in 597/98; and for Cilicia in 537 and 550. See McCormick et al., "Geodatabase," under these years for further details, as well as the following.

Five of seven Roman inscriptions documenting the construction, maintenance, and protection of public waterworks in Palestine cluster in the sixth century. See Leah Di Segni, "The Water Supply of Palestine in Literary and Epigraphical Sources," in David Amit et al. (eds.), The Aqueducts of Israel (Portsmouth, R.I., 2002), 57-67; Nahman Avigad, "A Building 
Whether the dry conditions documented in northeastern France for two centuries beginning c. 450 were connected with those indicated by the Levantine proxy data from the same general period is at present unclear, but deserves further study. Similarly, whether these changing climate conditions had something to do with the two centuries of devastating plague outbreaks that began in the eastern Mediterranean in 54I and quickly spread around the former Roman world remains to be seen. What Figure $6 \mathrm{~b}$ drives home is that, in the eastern Roman Empire, the quarter-century that included the event of 536 and the outbreak of the Justinianic pandemic of plague was marked by the highest number of famines (eight) recorded for the entire period under review. This new in-

Inscription of the Emperor Justinian and the Nea in Jerusalem (Preliminary Note)," Israel Exploration Journal, XXVII (I977), I45-I5I; Christopher P. Jones, "Procopius of Gaza and the Water of the Holy City," Greek, Roman, and Byzantine Studies, XLVII (2007), 455-467. Although the timing of public works undoubtedly was subject to political influence, it is consistent with signs of increasing drought. In fact, that water problems continued after the great drought ended c. 520 is suggested by the events mentioned above and strengthened by the additional six wells or cisterns that Justinian $(527-565)$ built across the Holy Land: Procopius of Caesarea, De aedificiis, 5, 9, I4-22, in Jakob Haury and Gerhard Wirth (eds.), Opera Omnia (Leipzig, I964), IV, I69.24-I70.4.

The longest aqueducts in the Roman Empire were created to bring water to the imperial capital of Constantinople during the fourth and fifth centuries. In the $520 \mathrm{~s}$, however, the capital usually experienced summer water shortages that the emperor sought to alleviate by starting construction in 527/28 on the great Yerebatan Saray1 cistern, which still survives. Procopius, De aedificiis, I, I I, IO-I4, 42.26-43.23; Malalas (ed. Johannes Thurn in Corpus Fontium Historiae Byzantinae, XXXV), Chronographia, I8, I7 (Berlin, 2000), 364-39-4I; Theophanes (ed. Carl De Boor), Chronographia, A.M. 6020 (Leipzig, I883), I, I76.26-7. Because the karstic aquifers that supplied Constantinople rapidly lost water after rain and yielded limited water in dry seasons, the situation reported for the 520 s may represent lessening summer precipitation compared to the previous 200 years. For the aquifers, see James Crow et al., The Water Supply of Byzantine Constantinople (London, 2008), I7-18, 25-26, who view reports of water shortages at Constantinople as reflecting underlying conditions and poor hydraulic management. Nevertheless, it seems unlikely that the planning and construction of the Roman Empire's longest water system during the previous 200 years had fallen short of the capital's anticipated normal summer supply and demand, assuming that the population remained approximately the same in the sixth as in the fifth century. However, the Sofular cave data point to a cooler and/or drier period from about 300 to about 500 in Bithynia (Figure Ib), almost $400 \mathrm{~km}$ east of the aqueduct's longest channel.

Bookman (Ken-Tor) et al., "Late Holocene Lake Levels of the Dead Sea"; Migowski et al., "Holocene Climate Variability and Cultural Evolution." The discrepancy in the proposed starting date of the wetter conditions (and therefore of the subsequent dry conditions) - c. 300 or C. 400 A.D. - lies within the 200-year range of the samples' radiocarbon accuracy at two standard deviations (see especially Migowski et al., "Holocene Climate Variability and Cultural Evolution," 428 [Appendix A]), but both studies concur that drying occurred sometime between C. 500 and 600 A.D. 
formation suggests that the nutritional background to the explosion of the Justinianic plague may reward deeper investigation. ${ }^{23}$

In central China, the Dulan-Wulan tree-ring chronology indicates that a wetter period from 380 to 440 A.D. gave way to severe drought lasting until 494. Above average precipitation then prevailed until 538 , followed by dry conditions from 539 to at least 568 and perhaps as late as 580 (Figure $8 \mathrm{~b}$ ). These decades of drought also may have stemmed from the ENSO phenomenon (see above and Figure $9 b-c$ ) and could well have led to the westward migration of more pastoral peoples from Central Asia. During the fifth-century drought, Hephthalite Huns invaded the Sassanian Empire, which neighbored the eastern border of the Roman Empire, and defeated and captured Peroz, its ruler, c. 469. Under the sixth-century dry conditions, the Avars suddenly began challenging the Roman Empire. They arrived north of the Black Sea around 550 and opened diplomatic relations with the Romans in 558. Sharp military conflict continued well into the 6oos. The Avars drove the Romans from their Danubian provinces and ultimately settled around present-day Hungary until they were destroyed by Charlemagne's Franks and by the Bulgars in the late eighth century. ${ }^{24}$

FROM INSTABILITY TO RECOVERY? 600 TO 800 A.D. In the seventh century, the economies and political structures of the successor kingdoms in Rome's former northwest provinces began a period of gradual recovery and growth. The collapsing eastern Roman Empire lost, reconquered, and then forfeited vast territories first to the Sassanian Empire of Persia and, then definitively, to the rising power of the Islamic caliphate.

23 The plague connection has been argued, so far unconvincingly, by several popular works of historical writing: Mike Baillie, Exodus to Arthur: Catastrophic Encounters with Comets (London, 2000); David Keys, Catastrophe: An Investigation into the Origins of the Modern World (London, I999), I8-I9; William Rosen, Justinian's Flea: Plague, Empire, and the Birth of Europe (New York, 2007), 200-203. The nutritional background to the explosion of the Justinianic plague may reward deeper investigation especially given that the Black Death of I 347 to I 353 that devastated Europe in much the same way had also been preceded by an exceptional sequence of famines during the earlier decades of the fourteenth century. See Léopold Genicot, "Crisis: From the Middle Ages to Modern Times," in Michael M. Postan (ed.), The Cambridge Economic History of Europe (New York, I97I), I, 672-674.

24 Richard N. Frye, "The Political History of Iran under the Sasanians," in Ehsan Yarshater (ed.), The Cambridge History of Iran (New York, 2000), III.I, I47. For the Avars, see Walter Pohl, Die Awaren: ein Steppenvolk im Mitteleuropa, 567-822 n. Chr. (Munich, I988). 
The overall picture in northwestern Europe is generally consistent with a shift to warmer temperatures from roughly 650 to about 750 , albeit with some variability among the different proxies. According to the sea-ice signal around seventh-century Greenland, warming prevailed until c. 735 , when cooling began to predominate at least until c. 800 (Figure 2a); the $\delta^{18} \mathrm{O}$ temperature proxy from central Greenland appears fairly stable (Figure 2c). Nevertheless, seventh-century volcanic events nearly reached the high levels of the third century. GISP2 $\mathrm{SO}_{4}$ reveals possible volcanic winters c. 639, 643, and 690; the deposits of 694 and 696 are within the ice core's margin of temporal resolution, possibly reflecting one or two eruptions. The twelve years from c. 690 to 702, when another volcanic eruption occurred, may well have been a difficult stretch for food production (Figures $2 \mathrm{~b}$ and $7 \mathrm{c}$, and Table I). Although only two eruptions (presuming 754 and 756 reflect the same event) marked the rest of the eighth century, GISP2's $\mathrm{SO}_{4}$ data for 766 ( \pm 2.5 years) correspond to the terrible winter of $763 / 64$, amply documented by eyewitnesses across western Eurasia. Written records of harsh winters in 698/99 and 752/ 53 also could be connected with volcanic deposits (Figure 6a; Table I). ${ }^{25}$

Swiss and Austrian glaciers present evidence that is consistent with the Greenland data. The Alpine glaciers' sixth-century advance was followed by a retreat phase when they seem to have melted back to late-twentieth-century sizes. The retreat probably culminated in the mid-eighth century. The next advance is documented by logs found in the Swiss Alps (Aletsch, Lower Grindelwald, and Gorner glaciers). The same is true in the eastern Alps where in situ logs indicate that already by 809 , the Gepatschferner had grown to a size similar to that in 1920 (Figure 5a). Whereas written records emphasize dry and wet conditions equally from c. 675 to 725 (Figure 6a), the precipitation record of northeast France (Figure $5 \mathrm{~b}$ ) indicates that the earlier dry conditions generally yielded to slightly wet or balanced summers from about 650 to about 800 , when precipitation conditions resembled those of the early Roman Empire. Central Europe saw a slow rise in precipitation that started c. 600 and stabilized c. 730 . The stable indications

25 McCormick et al., "Volcanoes and the Climate Forcing of Carolingian Europe." For additional details, see McCormick et al., "Geodatabase," under the years 688/89, 752/53. 
of the Eiffel maars shift to a slight trend toward warmer temperatures during the eighth century (Figures 3 and 4 ). ${ }^{26}$

Austrian Alpine summer temperatures seem largely consistent with the overall picture, being relatively warm in the seventh century. They are, however, reconstructed as cooler in the early eighth century before becoming warmer in the middle and cool in the second half of the century (Figure 5a) - a trend that continued and intensified until c. 840. During this period, the solar signal and Austrian speleothem also appear to diverge from the other evidence, insofar as they indicate cooling and/or drying from the later seventh century (Figures $\mathrm{Ia}-\mathrm{b}$ ). In general, the evidence points to wetter or more balanced precipitation and warming, followed by some cooling in western Europe during the later seventh and eighth centuries, suggesting a broadly favorable context for the gradual economic recovery of Europe that is increasingly apparent from the archaeological and written evidence.

In the Middle East, precipitation remained low. Both chronologies of Dead Sea levels agree that 200 years of wet conditions yielded to dropping lake levels in the seventh and eighth centuries and beyond, indicating a decline of precipitation in the areas that had been, or still were, under Roman control. This finding is consistent with the rare contemporary written reports, in which mentions of drought equal or exceed those of precipitation events (Figure 6b). It is also congruent with the Greenland evidence for summer circulation and longer summers that prevailed from c. 540 to until c. 735 and their expected association with less precipitation in the Middle East (see Figure 2c). As noted above, North Atlantic sea ice started to advance at that time, and the region began

26 Joerin et al., "Multicentury Glacier Fluctuations"; Holzhauser et al., "Glacier and LakeLevel Variations"; Nicolussi and Patzelt, "Untersuchungen zur holozänen Gletscherentwicklung." Moreover, in situ logs at the Suldenferner glacier prove that c. 836, it had advanced clearly beyond its extent in I920 A.D., probably approaching its Little Ice Age maximum extent. See Nicolussi et al., "Precisely Dated Glacier Fluctuations." Comparisons with the Alpine temperature record suggest that this glacier advance probably culminated c. 840. In the eastern Alps, this was the strongest advance during the first millennium A.D.

Büntgen et al., "2500 Years," 580. Drought occurred in North Africa c. 707/I I; in Ireland, there was a drought in 714, a dry summer in 719, and a rainy summer in 720 . Flooding occurred in France in an unspecified season of 7II, although the northeastern French dendrodata indicate dry AMJ conditions; Rome flooded in 7I6/I7. For the historical records, see McCormick et al., "Geodatabase"; for the dendrodata, Büntgen et al., "2500 Years"; data from Figure $\mathrm{S}_{4}$ at http://www.ncdc.noaa.gov/paleo/pubs/buentgenzo I I/buentgenzo I I. html. For the Eifel data, see Appendix (8). 
to cool again. A cooling trend persisted until c. 80o, although no clear evidence of a corresponding increase in Levant precipitation (Figure 2a) exists at present. ${ }^{27}$

The written records also suggest that unusually cold winters were more common in the Middle East from c. 600 to 724 (Figure $6 \mathrm{~b}$ ) - an idea that tallies in a general way with the exceptional frequency of volcanic events (Figures $2 \mathrm{~b}$ and $7 \mathrm{c}$; Table I). The Sofular speleothem indicates a partially concordant pattern in Bithynia: After a warming and/or wetter trend during the first half of the seventh century, drier and/or cooler conditions increased until the end of the period (Figure $\mathrm{Ib}$ ). In other words, the climatic picture remains sketchy for the era and area that saw the rise of the Islamic Empire and its near global economy in the late seventh and eighth century; the new civilization's center moved outside of the former Roman Empire to Baghdad in 762 A.D. It is possible, however, that cooler and less dry conditions appeared within the eighth century. The climatic context certainly merits greater consideration as more high-resolution proxy data become available, and as archaeological evidence and written documentation yield more information about the contribution of irrigation canals to the agrarian economy of the rising caliphate, even as early as the period from 709 to $719 .^{28}$

Finally, in central Asia, average precipitation continued until c. $68 \mathrm{o}$, when a century and half of below-average precipitation began (Figure 8a).

OUTLOOK: FUTURE DIRECTIONS IN THE CLIMATE HISTORY OF THE ROMAN EMPIRE Specific climate conditions as experienced by different regions and robustly documented by eleven independent proxy data sets coincide with, and probably help to explain, the early expansion of the Roman Empire and the later success of the eastern Roman Empire while its western counterpart declined.

27 Bookman (Ken-Tor) et al., "Late Holocene Lake Levels of the Dead Sea"; Migowski et al., "Holocene Climate Variability and Cultural Evolution." The contemporary written reports mention eight or nine droughts-600/oI, 658, 676/78, 687, 693, 721, 742-744 (Syria and Egypt), and 746/47-and four flooding or precipitation events-667, 716 (hail), 724/25, 740. See McCormick et al., "Geodatabase."

28 The contemporary written records mention twelve harsh winters-609/10, 623, 628, 662 (late frost), 667/68, 668-670, 683/84, 698/99, 707, 715, 717/18. See McCormick et al., "Geodatabase." For irrigation canals, see Alan Walmsley, Early Islamic Syria: An Archaeological Assessment (London, 2007), I IO-I I I, I I4-I I 5 . 
Drought conditions in Central Asia show a connection with the migration of the Huns and the Avars that brought turmoil to the Roman Empire. Volcanic activity was less prevalent in generally stable periods and more common in centuries known to have been politically, economically, and militarily turbulent. In particular, multiple proxy indicators are consistent with the cooling event of 536 A.D., recently identified as a major environmental moment in the history of the Roman Empire.

The favorable and exceptionally stable conditions that prevailed across the Roman Empire from c. IOO B.C. to C. 200 A.D. probably fostered the Empire's unparalleled rise (Figure II). Natural-scientific proxy data are more abundant for the western provinces of the Empire, where glacier retreat, Greenland ice-core findings, dendroecological data on precipitation and temperature, the Spannagel speleothem, and the spread of warmth-loving biota all testify to prolonged warming and wet conditions. Advantageously wet conditions also prevailed in the Roman Levant, where two extensive periods of moist conditions were separated and succeeded by dry conditions. The Nile floods and concomitant harvests were unusually favorable during this era of growth and prosperity.

In other words, the climate was not always changing enough to cause strain on Roman civilization. However, multiple proxy data sets show that this stability began to dissipate between about I 50 and 200 A.D., at the same time that the Empire confronted grave economic, political, and military challenges. The first wet period in the Roman Levant also came to an end in the third or fourth century. The exceptionally favorable Nile flood and harvest patterns, on which the Roman economy had perhaps come to rely, seem to have trended to less favorable conditions after I 55 A.D.

Climate conditions improved c. 300 A.D., at the same time that the Roman Empire recovered, although the earlier climate stability never returned. Around 400 A.D., fluctuation again increased in the western Roman Empire; several indicators point to colder and wetter conditions until precipitation dropped sharply in the first half of the sixth century, at least in northeastern Gaul and in what is now modern Germany. Although radiocarbon dating leaves the exact timing still unclear, sometime between the fourth and the fifth centuries A.D., lake levels show that favorable 
Fig. 11 Overview of Selected Indicators

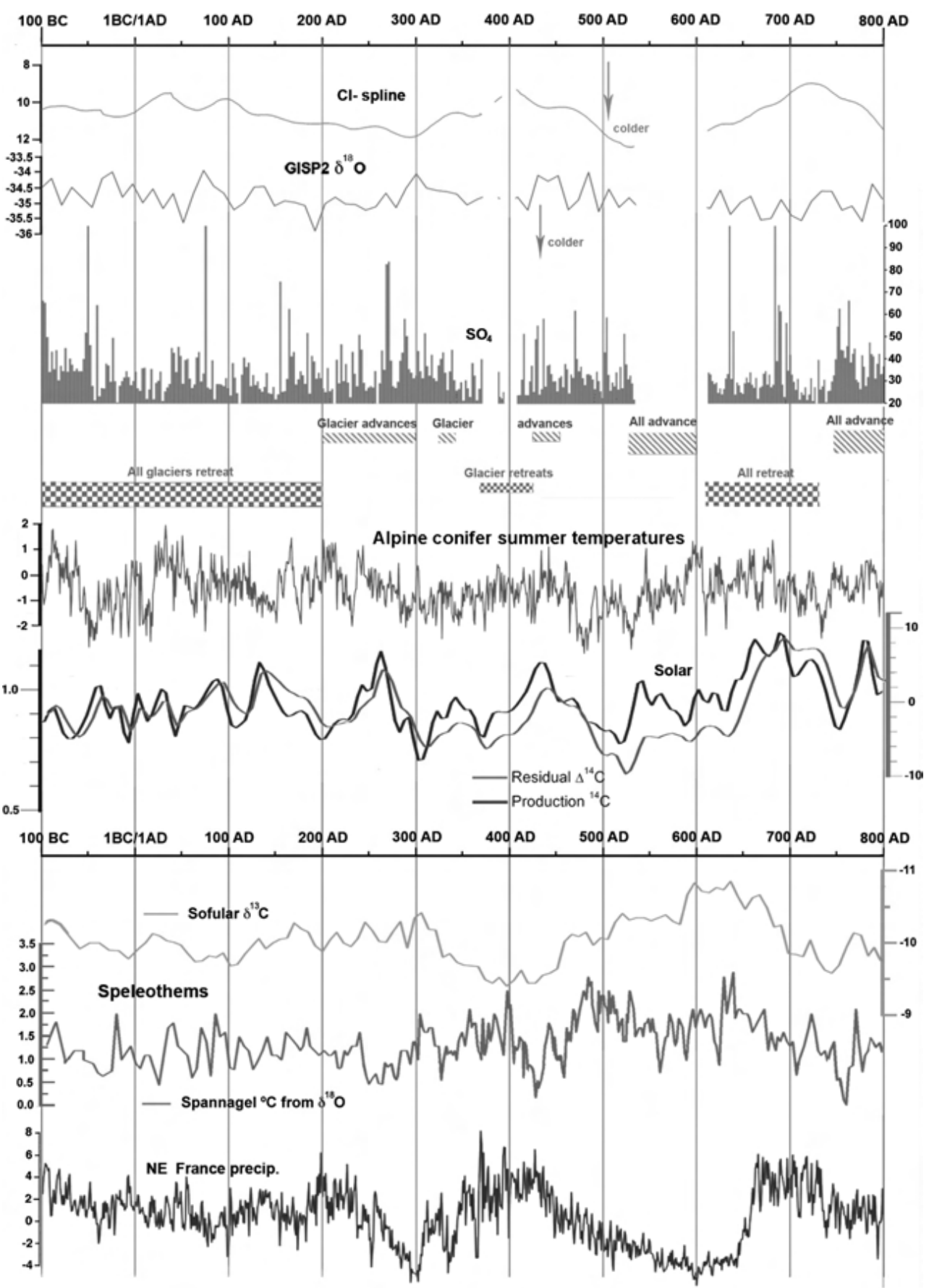

NOTE The X-axis of B.C.-A.D. years in this figure runs from left to right. The Cl- values have been inverted to make the direction of variation consistent with the temperature records. 
wet conditions returned to the Levant and persisted for about two centuries. Such regionally advantageous climatic developments might help to explain the success of the eastern Roman Empire as the western Empire dissolved into new polities; future research will surely resolve the chronology and clarify this issue.

Signs of hydroclimatic difficulties multiplied in the eastern Empire during the sixth and seventh centuries. The sixth century's fluctuations-exceptional cooling in both parts of the Empireand declining precipitation-possibly across the whole of western Eurasia-would have affected the Levant more seriously than it would have affected well-watered western Europe. Lesser levels of precipitation seem to have continued in the East at least until the eighth century. Generally more favorable conditions returned to western Eurasia around the later seventh century. In the west, new proto-towns, the trading emporia, emerged near the North Sea; the new kingdoms gained strength in England, France, and Italy; and agrarian expansion was underway. In the east, the Empire of the caliphate expanded into Spain and simultaneously relocated its center of gravity east of the late Roman one, ultimately settling on Baghdad.

The findings surveyed in this article introduce a new set of environmental conditions and questions that historians, archaeologists, and climate scientists must henceforth consider when following the complex chains of causality that resulted in the expansion of Roman power from the first century B.C. onward, the crises and eventual recovery of the Empire from the third to the fourth century A.D., the contrasting fates of the two halves of the Empire in the next two centuries, and the deep transformations of the seventh and eighth centuries. They will need considerable amplification and revision. Even so, these preliminary observations demonstrate for the first millennium the kinds of raw data and explanatory information that the interdisciplinary study of climate and its impact on human populations can generate by means of coordinated high-resolution, multi-proxy scientific, historical, and archaeological investigation.

Further improvements will certainly accrue with the accumulation of more high-resolution scientific proxy data from crucial but underdocumented areas of the Roman Empire and its successor societies, especially the Balkans, southern Europe, the Middle 
East, and North Africa. A continuing collaboration among archaeologists and climate scientists is necessary to resolve definitively the dating of otherwise unambiguously attested phenomena, such as the long periods of drier and wetter conditions in the Levant. Moreover, researchers must work to synthesize historical and proxy-climate observations that are inevitably sparse in time and space into a framework that is both dynamically consistent from the climatic perspective and historically rigorous. One important step in the right direction will be the development of focused regional and microregional case studies that can use highly resolved climate data, as well as archaeological and historical evidence, to explore the potential effect of both gradual and rapid climate change, and fluctuation, on human societies, and the complex patterns of human responses.

The intricate relationship between changing natural conditions and major events in human history may generate the most contentious questions in the short run, but it will also lead to the greatest insights over the long haul. A few examples are suggestive of future directions of research in this area. Regarding short-term change, the potential of extreme volcanism to cause rapid cooling and disrupt harvests has already been demonstrated for the earlier Roman period and for the end of the first millennium. Although the Roman written record is much thinner than the medieval one, there does seem to be a positive-and no negative-association between the sporadically surviving historical accounts of extreme winters and volcanic aerosols in the northern hemisphere, as recorded in GISP2 (see Table I). One priority for historians should be to investigate in greater detail the written evidence for agrarian and economic difficulties during the years when the ice cores indicate the likelihood of extreme winters. ${ }^{29}$

Regarding broader-gauge change, the varying precipitation trends in spring for northeastern France and Germany must have affected water tables and growing seasons. Archaeological and historical investigations should test the affected regions for possible causal links between precipitation and human behavior-say, shifts in settlement locations and crop spectrums. Similarly, the changing precipitation regimes in the Levant, once they are ro-

29 Rossignol and Durost, "Volcanisme global et variations climatiques"; McCormick et al., "Volcanoes and the Climate Forcing of Carolingian Europe." 
bustly dated, will need to be evaluated, alongside evolving patterns of urban demand, for their effect on production in some of the choicest agrarian areas of the later Roman Empire, such as the Syrian Hauran and the famed vineyards in the area known today as the Negev Desert. ${ }^{30}$

This synthetic view of climatic conditions during nine centuries across western Eurasia is but the first step on a long path of exploration that promises to open a new vista on how societies confronted and ultimately overcame the challenges of climate change during the first millennium. If this article represents a robust point of departure for future investigations by historians, archaeologists, and climate scientists that enhance its sketch of climate conditions in the Roman and post-Roman world, it will have served well the dawning age of consilient interdisciplinary investigation of the human and natural past.

\section{APPENDIX: MATERIALS AND METHODS}

(I) HISTORICAL EVIDENCE: THE ROMAN EMPIRE AND ITS NEIGHBORS (FIGURES 6A-B; IO) A new "Geodatabase of Historical Evidence on Roman and Post-Roman Climate" comprises (as of July 20 I I) 77I environmental events, overwhelmingly climatic, reported in the Greek, Latin, and Near Eastern written records of the Roman Empire and its neighbors between IOO B.C. and 800 A.D. It was created by McCormick, Kyle Harper, and More, with help from Kelly Gibson, based on existing compilations and original research. The written records are unevenly distributed over time, space, and type of phenomenon recorded. They do not suffice to reconstruct the Roman climate but offer a powerful eyewitness check on indices deduced from natural-scientific evidence. ${ }^{31}$

We classified all events in the written sources by phenomenon strength, by documented extent over space, and by record reliability - from I to 4 (maximum). Only phenomena at strengths and reliability 3 and 4 qualified for this analysis. Strong events documented in only one province were not excluded; the sparseness

30 For a first exploration of possible causal links between precipitation and human behavior in the light of the new data, see McCormick, "Climate Science, Ausonius, Nile Floods." 3 I Hennig, Katalog bemerkenswerter; Weikinn, Quellentexte zur Witterungsgeschichte Europas; Teleles, Meteorologika phainomena; Stathakopoulos, Famine and Pestilence. 
of ancient records often makes silence elsewhere insignificant. Phenomena with such limited reference could have affected a larger area than is recorded. The usable database numbered 499 securely attested climate events: 244 Nile floods (51.4\%), 68 cases of unusual precipitation or non-Nile flooding (I4.3\%), 92 famines (I9.2\%), 47 droughts (9.7\%), 8 heat events (I.7\%); and 40 cold winters $(8.4 \%){ }^{32}$

The eastern Roman Empire and its successors are betterdocumented than the western provinces, thanks to the remarkable record of Nile flooding between IOO B.C. and 299 A.D. developed by Bonneau, and the data taken from Arabic records from 622 to 800 as developed by Popper. The indirect but abundant and relatively robust data about Nile flood levels in the Roman period have never before been used for climate history. The data from the Muslim era (from 622 A.D. to the end of the Middle Ages and beyond) have figured in earlier studies, and apparently are more direct, since they are presented explicitly as counts of the height of Nile floods in cubits. This post-Roman data have yet to be fully tested for authenticity. The sixteen records from 64I to 744 A.D. that Popper appeared to identify as the least problematical are the only ones included in this study, though with caution. The Roman Nile record allows a new indirect history of tropical rains in Ethiopia and Central and East Africa. ${ }^{33}$

Beyond the Nile records, general climatic events in the eastern Roman Empire before the third century are poorly documented at present; over the entire period under review, the western provinces are more evenly recorded. More evidence will surely emerge as scholars consider the rich written and epigraphical sources of the prosperous eastern provinces. For the entire Empire, other ancient sources such as medical writings, letter collections, or calendrical documents will likely further expand the

32 Only phenomena at strengths and reliability 3 and 4 qualified for this analysis, except for Nile flood strengths, which include data on normal floods (rated conventionally in this case as “0.06").

33 Bonneau, Le fisc et le Nil; William Popper, The Cairo Nilometer: Studies in Ibn Taghrî Birdî's Chronicles of Egypt (Berkeley, I95I). Studies that have accepted the Nile data without questioning include Klaus Fraedrich et al., "Multiscale Detection of Abrupt Climate Changes: Application to River Nile Flood Levels," International Journal of Climatology, XVII (I997), I3OI-I 3 I 5 ; D. Kondrashov et al., "Oscillatory Modes of Extended Nile River Records (A.D. 622-1922)," Geophysical Research Letters, XXXII (2005), Li0702. According to Popper, Cairo Nilometer, I30, some of the dates of the annual flood records presented in the tables in Umar Tusun, Mémoire sur l'histoire du Nil (Cairo, 1925), have been arbitrarily and tacitly changed. 
documentary base. Specialists of the medieval Arabic traditions will be able to contribute as well, although the most important materials probably will postdate 800 A.D. ${ }^{34}$

Archaeological evidence is growing, as the examples cited in the notes attest, but it is widely dispersed and sometimes lacking the fine chronological resolution required for evaluating cause and effect.

For further information, see the "Geodatabase of Historical Evidence on Roman and Post-Roman Climate," posted on the website, "Digital Atlas of Roman and Medieval Civilizations," edited by McCormick et al., at http://darmc.harvard.edu.

(2) GREENLAND ICE CORES: GISP2, GRIP (FIGURE 2) The GISP2 major ion record has significance for the climate of the Roman Empire/Northern Hemisphere.

Sulfate provides a proxy for volcanic activity (Figure $2 \mathrm{~b}$ ). Violent volcanic eruptions spew massive amounts of particles into the atmosphere. Microscopic particles, if lifted into the stratosphere as an aerosol-solid or liquid particles suspended in a gas, in this case, the atmosphere (for example, a cloud) — can diminish the global temperature by blocking solar radiation. Such volcanic emissions typically are rich in sulfur dioxide $\left(\mathrm{SO}_{2}\right)$ which combines with water $\left(\mathrm{H}_{2} \mathrm{O}\right)$ to form sulfuric acid $\left(\mathrm{H}_{2} \mathrm{SO}_{4}\right)$. In addition to reflecting solar radiation back into space and thereby cooling the earth, the aerosols also fall to earth. The resultant sulfate $\left(\mathrm{SO}_{4}\right)$ particles are preserved in the millennial record of atmospheric deposits - snow - in the Greenland glaciers, and measured in parts per billion ( $\mathrm{ppb}$ ) by mass spectrometry. ${ }^{35}$

The isotope record (Figure 2c) provides a proxy for temperature in central Greenland, which usually has indicative value for the broader trend in the northern hemisphere. Ice consists of frozen water $\left(\mathrm{H}_{2} \mathrm{O}\right)$. The oxygen atoms occur mainly as the common isotope ${ }^{16} \mathrm{O}$ and the rare heavier isotope ${ }^{18} \mathrm{O}$. Ice formed under colder conditions generally has fewer atoms of ${ }^{18} \mathrm{O}$. The ratio

34 Steffen Vogt et al., "Assessing the Medieval Climate Anomaly in the Middle East: The Potential of Arabic Documentary Sources," PAGES news, XIX (20I I), 28-29.

35 Mayewski et al., "Major Features and Forcing of High-Latitude Northern Hemisphere Atmospheric Circulation Using a i ro,ooo-Year-Long Glaciochemical Series," Journal of Geophysical Research, CII (1997), 26345-26366; G. A. Zielinski et al., "Record of Volcanism since 7000 B.C. from the GISP2 Greenland Ice Core and Implications for the Volcano-Climate System," Science, CCLXIV (I994), 948-952. 
of ${ }^{16} \mathrm{O}$ to ${ }^{18} \mathrm{O}$ is described as $\delta^{18} \mathrm{O}$, and measured in "per mil" (one part per thousand) symbolized by \%o. In the Greenland record, one per mil of $\delta^{18} \mathrm{O}$ is equivalent to a temperature difference of c. I. $5^{\circ}$ C. For more details, see http://www.iceandclimate.nbi.ku. $\mathrm{dk} / \mathrm{research} / \mathrm{past}$ atmos/past_temperature_moisture/. Two time intervals are missing in the relevant segment of GISP2 (c. 386 to 407 and c. 54I to 6I 3 [ \pm ca. 2.5 years]). The GRIP ice-core record provides a parallel and more detailed set of readings for the isotopic temperature record. ${ }^{36}$

Chloride (Cl-; Figure 2a) provides a proxy for sea-ice extent in the North Atlantic. Higher $\mathrm{Cl}$ - indicates more extensive sea ice and lower $\mathrm{Cl}$ - indicates less sea ice. Higher $\mathrm{Cl}$ - arises from the greater storminess associated with expanding sea ice and increased marginal areas of sea ice, which are the most productive zones for propelling aerosols incorporating $\mathrm{Cl}$ - into the atmosphere, eventually to be deposited in snow in central Greenland, where it can be measured in ice cores. If the North Atlantic has more (less) sea ice, the area around Greenland is generally cooler (warmer) and winter (summer) atmospheric circulation dominates. Longer winters (inversely longer summers) are related to more (less) precipitation in the Middle East. Therefore, GISP2 Cl- offers a view of both temperature and drought through signaling the duration and strength of winter vs. summer circulation patterns. Spline refers to a particular mathematical technique of joining points on a graph to form a curve. ${ }^{37}$

GISP2 data available online at http://www.ncdc.noaa.gov/ paleo/icecore/greenland/summit/document/gispdata.htm.

GRIP $\delta^{18} \mathrm{O}$ data are available online at ftp://ftp.ncdc.noaa. gov/pub/data/paleo/icecore/greenland/summit/grip/isotopes/ gripd I 8o.txt.

(3) SOlAR ACTIVITy (FIgURE IA) Radiocarbon $\left({ }^{\mathrm{I}} \mathrm{C}\right)$ is produced when cosmic rays enter the earth's upper atmosphere; modulation of the cosmic ray flux because of changes in solar magnetic activity, signaled notably by sunspot activity, explains the majority of

36 P. M. Grootes et al., "Comparison of Oxygen Isotope Records from the GISP2 and GRIP Greenland Ice Cores,” Nature, CCCLXVI (I993), 552-554.

37 For chloride as a proxy, see Mayewski et al., "Changes in Atmospheric Circulation and Ocean Ice Cover over the North Atlantic during the Last 4I,ooo Years," Science, CCLXIII (I994), I747-I75I. 
shorter-term variation in radiocarbon production during the last several thousand years. The radiocarbon record thus provides one key proxy for past solar activity. In general terms, increased radiocarbon production (the low points in Figure Ia) reflect less solar magnetic activity (and fewer sunspots); it is associated with cooler conditions on earth. Reduced production means the inverse, as can be verified for the last few hundred years through the correlation of the radiocarbon-solar activity record with recorded sunspot activity. The radiocarbon-derived solar-activity record seems to provide a macro-climate-driving parameter. The evidence increasingly suggests a link between changes in solar activity and significant episodes of climate change on earth (especially, the increases in radiocarbon production corresponding to marked cooling periods). ${ }^{38}$

The residual $\delta^{\mathrm{I}} \mathrm{C}$ record data after removing a moving I, OOOyear average are as published/available for the standard northern hemisphere ${ }^{14} \mathrm{C}$ calibration records of IntCalo4 and IntCalo9. The ${ }^{14} \mathrm{C}$ production is an approximation of ${ }^{14} \mathrm{C}$ production, calculated using a standard box model of the carbon cycle from the decadal tree-ring data of IntCal98. The Total Solar Irradiance (TSI) record is also calculated from the ${ }^{14} \mathrm{C}$ record; it is measured in watts per $\mathrm{m}^{2}$. We prefer the Tsi derived from known age tree rings, instead of a recent solar irradiance reconstruction from Beryllium-Io $\left({ }^{\mathrm{I}} \mathrm{Be}\right)$ from polar ice-cores, because of some uncertainties in the timescale of the ice-cores (these are small only for the Roman period, but become significant by the mid-second millennium B.C.). For the period shown in Figure Ia, the ${ }^{\mathrm{I}} \mathrm{Be}$-based solar irradiance record is nonetheless very similar in trend and timings.

38 G. Bond et al., "Persistent Solar Influence on North Atlantic Climate during the Holocene," ibid., CCXCIV (200I), 2I 30-2 I36; L. Gray et al., "Solar Influences on Climate," Reviews of Geophysics, XLVIII (20I0), RG400I; S. K. Solanki et al., "Unusual Activity of the Sun during Recent Decades Compared to the Previous I I,00o Years," Nature, CDXXXI (2004), I084-I087; S. R. O’Brien et al., "Complexity of Holocene Climate as Reconstructed from a Greenland Ice Core," Science, CCLXX (1995), I962-I964; Manning, "Radiocarbon Dating and Climate Change," in Mainwaring et al. (eds.), Climate Crises in Human History, 25-59; idem, "The Roman World and Climate: Context, Relevance of Climate Change, and Some Issues," in Harris (ed.), Ancient Mediterranean Environment (in press), with further discussions of the data and material discussed in this article; S. Björck et al., "High-Resolution Analyses of an Early Holocene Climate Event May Imply Decreased Solar Forcing as an Important Climate Trigger," Geology, XXIX (200I), I I07-I I IO; D. Mauquoy et al., "Changes in Solar Activity and Holocene Climatic Shifts Derived from ${ }^{14} \mathrm{C}$ Wiggle-Match Dated Peat Deposits," Holocene, XIV (2004), 45-52. 
The residual data set is available at http://www.radiocarbon.org/IntCalo4\%2ofiles/resido4_IOoO.I4c. The TSI data set is available at https://www.mps.mpg.de/projects/sun-climate/data/ tsi_hol.txt. ${ }^{39}$

(4) SPELEOTHEM RECORDS (Figure ib) Speleothems are formed by water seeping through rock and depositing minerals in caves. Analysis of isotopic ratios, particularly of $\delta^{18} \mathrm{O}$ (for oxygen isotopes and temperature, see Appendix [2]) and $\delta^{13} \mathrm{C}$ (for carbon isotopes as a measure of effective moisture and so generally precipitation) deriving ultimately from the precipitation that supplies water to the process, provides evidence for past regional climates. Speleothems display changing profiles in their composition that can relate to seasonal rhythms. Potential complications to detecting the palaeoclimate signals in speleothems involve the local geochemistry, alternate water sources, and the difficulty and expense of establishing high-resolution (closely dated) chronology. ${ }^{40}$

There are as yet few high-resolution speleothem records pub-

39 Paula J. Reimer et al., "IntCalo4 Terrestrial Radiocarbon Age Calibration, o-26 Cal Kyr BP," Radiocarbon, XLVI (2004), I029-I058; eadem et al., "IntCalo9 and Marineog Radiocarbon Age Calibration Curves, 0-50,000 Years Cal BP," ibid., LI (2009), I I I-I I58. For the box model of the carbon cycle, see U. Siegenthaler et al., " ${ }^{\mathrm{I} 4} \mathrm{C}$ Variations Caused by Changes in the Global Carbon Cycle," ibid., XXII (I980), I77-I9I-based on the assumption that oceanic ${ }^{\mathrm{I} 4} \mathrm{C}$ uptake was constant during this time, as described by I. G. Usoskin and B. Kromer, "Reconstruction of the ${ }^{\mathrm{I} 4} \mathrm{C}$ Production Rate from Measured Relative Abundance," ibid., XLVII (2005), 32, from the decadal tree-ring data of IntCal98 (data for Figure ra kindly provided by Bernd Kromer). For the Tsi reconstruction from the ${ }^{\mathrm{I}} \mathrm{C}$ record and the methods involved, see L. E. A. Vieira et al., "Evolution of the Solar Irradiance during the Holocene," Astronomy \& Astrophysics, DXXXI (A6) (201 I), doi: I0.105I/0004-636I/201015843. For IntCal98, see M. Stuiver et al., "IntCal98 Radiocarbon Age Calibration, 24,000-o Cal BP," Radiocarbon, XL (I998), I04I-I083. For the recent ${ }^{\mathrm{I}}{ }^{\circ} \mathrm{Be}$ Solar Irradiance reconstruction noted in the Appendix, but not used in Figure Ia for the reasons stated, see F. Steinhilber et al., "Total Solar Irradiance during the Holocene," Geophysical Research Letters, XXXVI (2009), Li9704, doi:IO.I029/2009GLo40I42. For uncertaintities with the relevant ice-core datings, even by the Late Roman period, and certainly by the mid-second millennium B.C., see, for example, J. Southon, "A Radiocarbon Perspective on Greenland Ice-Core Chronologies: Can We Use Ice Cores for ${ }^{14}$ C Calibration?” Radiocarbon XLVI (2004), I239-I259; M. G. L. Baillie, "Proposed Re-dating of the European Ice Core Chronology by Seven Years Prior to the 7th century AD," Geophysical Research Letters, XXXV (2008), Li58I3, doi:Io.io29/ 2008 GLo34755.

40 On extracting climate signals from speleothems, see F. McDermott, "Palaeo-climate Reconstruction from Stable Isotope Variations in Speleothems: A Review," Quaternary Science Reviews, XXIII (2004), 90I-9i 8. For a recent high-resolution speleothem record from China showing the potential, see P. Zhang et al., "A Test of Climate, Sun, and Culture Relationships from an I8 Io-Year Chinese Cave Record," Science, CCCXXII (2008), 940-942 (from the Wanxiang Cave, China, covering I92 to 2003 A.D. at a three-year resolution). For the factors that can complicate the climate evidence derived from $\delta^{18} \mathrm{O}$ in speleothems, see Matthew 
lished for IOO B.C. to 800 A.D. in this region of the world. By high resolution we mean data at least on a decadal scale, ruling out several older records - the fairly coarse original Soreq Cave (Israel) data set and a new Soreq record c. 2,200 B.P. to 900 B.P. Two recently published data sets are of interest: (I) an inferred temperature reconstruction (from an original $\delta^{18} \mathrm{O}$ record) from Spannagel Cave in the Central Alps (Austria, representing the northwestern Roman world), which allows the reconstruction of annual temperatures, and (2) a $\delta^{13} \mathrm{C}$ record from Sofular Cave, northwestern Turkey (Roman Bithynia, Asia Minor), which allows inferences of humidity (and/or warmth) and aridity (and/or cooling), offering a moisture (precipitation) record. The data are available online at http://www.ncdc.noaa.gov/paleo/pubs/manginizoos/ mangini2005.html and http://www.ncdc.noaa.gov/paleo/pubs/ fleitmann2009/fleitmann2009.html. ${ }^{41}$

(5) AUStrian AND SWiss Glaciers (Figure 5A; Figure i i) Alpine glaciers are strong indicators for mid- to long-term climate variability. Our knowledge of their changes in the first millennium A.D. has increased remarkably, due to new dendrochronologically established calendar dates for several past glacier advances, which are much more precise than radiocarbon dating. So far, the new dates from the first millennium concern only some of the relevant glaciers, usually large ones that display relatively slow reaction times to changing climate signals. Dates established by multiple trees are available for the Great Aletsch, the Lower Grindelwald, and the Gepatschferner glaciers; dates identified by one tree are available for the Gorner glacier and the Suldenferner. ${ }^{42}$

S. Lachniet, "Climatic and Environmental Controls on Speleothem Oxygen-Isotope Values," Quaternary Science Reviews, XXVIII (2009), 4I2-432.

$4 \mathrm{I}$ For the recent Soreq record, the dating precision of which appears questionable to us, see Ian J. Orland et al., "Climate Deterioration in the Eastern Mediterranean as Revealed by Ion Microprobe Analysis of a Speleothem That Grew from 2.2 to $0.9 \mathrm{ka}$ in Soreq Cave, Israel," Quaternary Research, LXXI (2009), 27-35 (regarding the problematical underlying dating, see, esp., 30 [Table I], 32 [Figure 6], and 33 [column I]), with further references. For the Spannagel record, see A. Mangini et al., "Reconstruction of Temperature in the Central Alps during the Past 2000 yr from a $\delta^{18} \mathrm{O}$ Stalagmite Record," Earth and Planetary Science Letters, CCXXXV (2005), 74I-75 I; for Sofular Cave, D. Fleitmann et al., "Timing and Climatic Impact of Greenland Interstadials Recorded in Stalagmites from Northern Turkey," Geophysical Research Letters, XXXVI (2009), Li9707. Since the climate relationships for the $\delta^{18} \mathrm{O}$ record in this case are not yet fully clear, we do not consider these data in this article.

42 Nicolussi et al., "A 9i I I Year Long Conifer Tree-Ring Chronology for the European Alps: A Base for Environmental and Climatic Investigations," Holocene, XIX (2009), 909-920. 
The current glacier retreat in the Alps, which is due to an instrumentally documented temperature increase, constitutes the most recent phase of a retreat period that started after the last Little Ice Age maximum around I 855 A.D. Since that date, about half of the Alps' glacier area has been lost.

Several factors complicate the use of glacier lengths as a proxy for past climate variability. Due to differing sizes and topographical situations, glaciers do not all behave in the same way: Steep smaller glaciers change length more quickly (whether in advance or retreat) subsequent to climate forcing than large and relatively flat glaciers do. Hence, the Great Aletsch, the Alps' largest glacier, has continuously retreated since its last Little Ice Age maximum c. I860 A.D., whereas other Alpine glaciers (Gepatschferner, Lower Grindelwald, and Suldenferner) have re-advanced two or three times during the same period, especially around I920 and I980 A.D. Such differences affect comparisons of the lengthchange history of different glaciers. Short but strong mass gains (as happened around I8I5 A.D., the time of the Mount Tambora eruption (Indonesia) and the subsequent volcanic "Year Without a Summer" in I 8 I6) also can lead to dynamic reactions with fast advances or even "surges," which a few Alpine glaciers have undergone (Suldenferner, for one). Specific topographical situations allow such sensitive reactions to massive snow/ice mass gains. ${ }^{43}$

Because the dimensions of individual glaciers vary, comparisons of the Holocene length-change history of Alpine glaciers are usually based on the relative extents of the same glacier observed for the past I5O years-for example, "the I920 A.D. extent." Moreover, the shape of a retreating glacier's tongue can differ from that of an advancing glacier and influence the interpretation of a glacier tongue's relative position.

(6) AUSTRIAN ALPINE DENDRODATA AND SUMMER TEMPERATURE (FIGURE 5A) The Austrian Alpine dendrodata offer a tree-ring record based on I,546 temperature-sensitive Stone pines (Pinus cembra; $N=$ I,089) and European larches (Larix decidua; $N=457$ ) from tree-line sites in the central eastern Alps. Their radial growth is dominated by summer (June, July, and August) temperature

43 Zumbühl and Holzhauser, "Alpengletscher in der Kleinen Eiszeit," Die Alpen, LXIV (1988), I30-322. 
variability. The recently published temperature reconstruction based on this Alpine data set covering the last 2,500 years shows strong correlations $(>0.6)$ not only to the Alpine area but also to parts of the Mediterranean and North Africa, at least for the calibration period. The temperature reconstruction is publicly available at http://www.ncdc.noaa.gov/paleo/pubs/buentgen2oI I / buentgenzor I.html, under "Alpine Conifer Data." ${ }^{44}$

(7) ANNUALLY RESOLVED RECONSTRUCTION OF JUNE PRECIPITATION ANOMALIES IN NORTHEASTERN FRANCE (FIGURE 5B) Oak growth in northeastern France has been proven to be sensitive to the monthly precipitation totals of April, May, and June. The reconstruction of precipitation anomalies is averaged for northeastern France $\left(48-50^{\circ} \mathrm{N}\right.$ and $\left.5-7^{\circ} \mathrm{E}\right)$, mainly for Lorraine, from 200 B.C. to 800 A.D., based on around 900 single-oak (Quercus spec.) ringwidth series. A well-replicated chronology allows annually resolved estimates of past hydroclimatic summer conditions there. Uncertainty bars of the reconstruction reflect the \pm I root mean square error (RMSE) computed from the calibration period. This data set can be used in conjunction with those recently established from even larger data sets for AMJ from northeastern France and from northeastern and southeastern Germany. ${ }^{45}$

The Iron Age and Roman samples mainly originate from archaeological excavations of buildings, strongholds, water supplies, and other infrastructure. Construction timbers are the major source for medieval to modern samples. The resulting composite chronology is characterized by an even distribution of series starting and ending dates. The mean segment length is 9I years with a maximum of $3 \mathrm{I} 4$ years. The average growth rate is $1.76 \mathrm{~mm}$.

The instrumental target was selected from a high-resolution $0.5^{\circ} \times 0.5^{\circ}$ grid-box dataset, covering the period from I90 I to 2002. The final reconstruction was developed to preserve inter-

44 Nicolussi et al., "A 9 I I Year Long Conifer Tree-Ring Chronology”; Büntgen et al., "A ro52-Year Tree-Ring Proxy for Alpine Summer Temperatures," Climate Dynamics, XXV (2005), I4I-I53; idem et al., "2500 Years," Figure SI I, available at http://www.sciencemag. org/content/early/20I I/oI/I2/science. I I97I75/suppl/DCi.

45 Idem et al., "Tree-Ring Indicators of German Summer Drought over the Last Millennium," Quaternary Science Reviews, XXIX (2010), I005-I0I6; Tegel et al., "Updating Historical Tree-Ring Records for Climate Reconstruction,” ibid., I957-I959; Büntgen et al., "2500 Years"; idem, "Supporting Online Material," I I, available at http://www.sciencemag.org/ content/early/20 I I/or/I2/science. I I97I75/suppl/DCi. 
annual to multicentennial long trends, scaled against June precipitation from I90 I to I975 and surrounded by an error bar. The skill of the method was validated by comparison with historical eyewitnesses of precipitation in the regions where the trees are located, from IOI 3 to I5O4 A.D. For the full data set, see http:// www.ncdc.noaa.gov/paleo/pubs/buentgen20 I I/buentgen20 I I . html, under "Figure $\mathrm{S}_{4}$ Oak Extremes." 46

(8) POLLEN SignALS FROM THE EIFEL PLATEAU, WESTERN GERMANY (FIGURES 3 AND 4) Lake Holzmaar (HZM, 50.129, $6.879^{\circ}$; 425 m.a.s.1.) is an extinct volcano located within the West Eifel Volcanic Field (Germany) about a day's travel (50 km) west of the Rhine frontier, and $40 \mathrm{~km}$ north of the late Roman capital of Trier. Several cores were collected from this maar lake by the Geo-ForschungsZentrum Potsdam. The chronology is based on varve (annual sedimentary layer) counting of core $\mathrm{B} / \mathrm{C}$ (cored in I984), which was cross-checked by counting varves of additional profiles. After comparison with calibrated accelerator mass spectometry (AMS) radiocarbon dates, the varve chronology (in varve year B.P., where "Before Present" refers to I950) has been corrected by adding 346 years between 3500 and 4500 cal. year. The resulting age model was assigned to the HzM $4 \mathrm{a} / 4 \mathrm{~b}$ composite profile (cored in I996) using about forty well-defined marker layers and linear interpolation. This composite profile has been used for high-resolution pollen analysis and for botanical-climatological transfer functions based on the palaeobotanical data. In this case, transfer functions are a quantitative tool that allows the reconstruction of climate features from the spectrum of botanical specimens recovered from lake deposits. ${ }^{47}$

46 Timothy D. Mitchell and Philip D. Jones, "An Improved Method of Constructing a Database of Monthly Climate Observations and Associated High-Resolution Grids," International Journal of Climatology, XXV (2005), 693-7I2; Büntgen et al., "2500 Years," 579; idem, "Supporting Online Material," 5 .

47 Core B/C was cross-checked via cores E/F/H from I990. See Bernd Zolitschka, Paläoklimatische Bedeutung laminierter Sedimente (Berlin, I998), I I-3 I. I. Hajdas et al., "AMS Radiocarbon Dating of Annually Laminated Sediments from Lake Holzmaar, Germany," Quaternary Science Reviews, XIV (I995), I37-I43; J. Baier et al., "Diatom and Geochemical Evidence of Mid-To Late Holocene Climatic Changes at Lake Holzmaar, West-Eifel (Germany)," Quaternary International, CXIII (2004), 8 I-96; Litt et al., "Vegetation and Climate History in the Westeifel Volcanic Field (Germany) during the Past I I ooo Years Based on Annually Laminated Lacustrine Maar Sediments," Boreas, XXXVIII (2009), 679-690. See T. Kumke et al., "Transfer Functions for Paleoclimate Reconstructions-Applications," in 
Meerfelder Maar (MFM, 50.10 ${ }^{\circ}, 6.76^{\circ} ; 336.5$ m.a.s.1.) is a second extinct volcano $9 \mathrm{~km}$ west of the Holzmaar. The MFM 6 varve sequence is a floating chronology, because in the uppermost I $80 \mathrm{~cm}$ of the profile, varves are not continuously preserved. Therefore, the MFM chronology has been linked to the calendaryear timescale via the Ulmener Maar Tephra, which has been identified in both sediment records of HZM and MFM and dated I IOOO calendar yr B.P. in the HZM record. Since varve counting was impossible in the uppermost sediments, this part of the MFM timescale (c. I,600 years) is based on extrapolated sedimentation rates derived from varve data and two calibrated AMs ${ }^{\mathrm{I}}{ }^{4} \mathrm{C}$ dates obtained from terrestrial macrofossils. ${ }^{48}$

The pollen data reflect the effect of human activity on vegetation until the third century A.D., as well as woodland regeneration until the eighth (Meerfelder Maar) or ninth century A.D. (Holzmaar). The temperature reconstructions based on pollen-transfer functions (probability-density functions) suggest climate stability until the eighth century A.D., insofar as can be detected in the Eifel's climate conditions. Note, however, that only the strongest climate changes would have had a marked effect on the composition of plant communities, because most recent climate variability fell within the climatic tolerance of those taxa. The maars might suggest a slight trend to warmer winter temperatures in the eighth century, but given the range of the probabilities, this interpretation is subject to caution.

(9) LEVANT PRECIPITATION AND LEVEL CHANGES IN THE DEAD SEA (FIGURE 7A) The Dead Sea basin is located between the Mediterranean climatic zone and the desert belt at the deepest terrestrial spot on earth. During the Quaternary, the Dead Sea basin accommodated a series of terminal saline to hypersaline lakes characterized by limnological properties (levels, configuration, and geochemistry). These properties reflect the hydrological conditions in their large drainage area, which in turn were controlled by the climatic systems of the Mediterranean (the source of most rains in

H. Fischer et al. (eds.), The KIHZ Project: Towards a Synthesis of Holocene Proxy Data and Climate Models (Berlin, 2004), 245-262.

48 A. Brauer et al., "AMS Radiocarbon and Varve Chronology from the Annually Laminated Sediment Record from Lake Meerfelder Maar, Germany,” Radiocarbon, XLII (2000), 355-368; Zolitschka, Paläoklimatische Bedeutung laminierter Sedimente. 
the region that are related to the Cyprus cyclones) and the deserts (source of some major floods). During the Holocene, the Dead Sea fluctuated between 370 and 430 m.b.s.l. (see Figure 7a). A key feature is a sill at 403 m.b.s.l. that separates the Dead Sea's two subbasins. Because enhanced evaporation in the southern basin buffers the lake's rise, a significant rise in level above the sill is required to allow the existence of a water-body over the entire Dead Sea basin, which provides a strong signal of major precipitation increases. ${ }^{49}$

The recent high-resolution and densely dated sedimentary records of the late Holocene Dead Sea were carried out in new gullies formed in the fast-retreating shores of the modern Dead Sea (c. I $\mathrm{m} / \mathrm{yr}$, mainly due to human interference). The sedimentary sections exposed in these gullies, located on the edges of fan deltas (for example, the Ze'elim Valley), are disrupted by several sedimentary unconformities that are related to low stands. Lake level, or stand, was significantly above the sill at 403 m.a.s.l. only during the mid-Holocene (between c. 6000 and 3500 B.P. with several fluctuations), and during the Roman and late Roman"Byzantine"-periods (c. I 400 to I 600 B.P., according to Migowski et al.). ${ }^{50}$

The Roman and late Roman periods were separated by a low stand. The high stands provide a strong signal of increased precipitation in the Levant. The first Roman high stand of the Dead Sea lasted a long time, four centuries or so, from about 200 B.C. to about 200 A.D. The ensuing low stand lasted more than a century; it was succeeded by a sharp increase in precipitation that continued for about 200 years. As discussed above, the two major studies differ on the timing of its onset by about one radiocarbon dated century, placing the beginning of wetter conditions c. 300 or c. 400 . The discrepancy is well within the range of the samples'

49 Figure 7a takes into account the curve as updated by Migowski et al., "Holocene Climate Variability and Cultural Evolution." N. Greenbaum et al., "The Hydrology and Paleohydrology of the Dead Sea Tributaries," Geological Society of America Special Papers, CDI (2006), 63-93; David Neev and K. O. Emery, The Destruction of Sodom, Gomorrah, and Jericho: Geological, Climatological, and Archaeological Background (New York, I995); A. Frumkin and Y. Elitzur, "Historic Dead Sea Level Fluctuations Calibrated with Geological and Archaeological Evidence," Quaternary Research, LVII (2002), 334-342; Bookman (Ken-Tor) et al., "Late Holocene Lake Levels of the Dead Sea"; eadem et al., "Quaternary Lake Levels in the Dead Sea Basin: Two Centuries of Research," Geological Society of America Special Papers, CDI (2006), I 55-I70; Migowski et al., "Holocene Climate Variability and Cultural Evolution." so Migowski et al., "Holocene Climate Variability and Cultural Evolution." 
AMS radiocarbon 200-year accuracy at two standard deviations. According to both studies, after the two centuries of favorably wet conditions, dry conditions continued through the eighth century. For archaeological evidence on Dead Sea levels, see Appen$\operatorname{dix}(\mathrm{I}){ }^{51}$

(IO) CENTRAL ASIAN PRECIPITATION/EVAPORATION SIGNAL FROM STABLE OXYGEN ISOTOPES: LAKE VAN (FIGURE 7B) Lake Van is situated on a high plateau in eastern Anatolia, Turkey. Its sediments, which have been laminated annually for nearly I4,0oo years, are ideal for creating high-resolution climate, tectonic, and volcanic histories. The lake's position at the junction of the atmospheric southwestern jet stream and northern branch of the subtropical high (the subtropical latitudes between 30 and 35 degrees, north and south) makes it climatically sensitive. Within the climate region of northeastern Anatolia, the Lake Van record represents an excellent continental archive for climate conditions between the Black Sea, the Arabian Sea, and the Red Sea. Continuous records of varve thickness, geochemistry, $\delta^{18} \mathrm{O}, \delta^{13} \mathrm{C}$, and pollen were used to distinguish different climate phases. The oxygen isotope ratio from two cores, measured on autochthonous aragonite and calcite, clarifies the climatic conditions during the Roman and postRoman period. The correlation of both isotope records is obvious. In Figure $7 b$, the data from Lemcke and Sturm are taken into account because of the direct link between varve counting and isotope signal. The high $\delta^{18} \mathrm{O}$ concentrations recorded at Lake Van are characteristic of terminal lakes, and the oxygen-isotope enrichment in closed systems is mainly controlled by fractionation processes connected to evaporation. ${ }^{52}$

5 I Bookman (Ken-Tor) et al., "Late Holocene Lake Levels of the Dead Sea," dates the low stand at 300; Migowski et al., "Holocene Climate Variability and Cultural Evolution," dates it at 400. See especially ibid., 428 (Appendix A).

52 G. Landmann et al., "Dating Late Glacial Abrupt Climate Changes in the I4,570 yr Long Continuous Varve Record of Lake Van, Turkey," Palaeogeography, Palaeoclimatology, Palaeoecology, CXXII (I996), I07-I I 8; Litt et al., “PALEOVAN': International Continental Scientific Drilling Program (ICDP): Site Survey Results and Perspectives," Quaternary Science Reviews, XXVIII (2009), I555-I567; Wick et al., "Evidence of Lateglacial and Holocene Climatic Change"; N. Roberts and Herbert E. Wright, "Vegetational, Lake Level, and Climatic History of the Near East and Southwest Asia," in Wright et al. (eds.), Global Climates since the Last Glacial Maximum (Minneapolis, I993), I94-220; H. M. Cullen and P. B. Demenocal, "North Atlantic Influence on Tigris-Euphrates Streamflow," International Journal of Climatology, XX (2000), 853-863; F. Lamy et al., "Multicentennial-Scale Hydrological Changes in the Black 
Based on the stable oxygen curves from both cores, maximum relative humidity was reached in the period between 8400 and 4IOO years B.P. After a phase of higher aridity between 4IOO and 2IOO years B.P., the climate conditions during the Roman and late Roman period were similar to those today, with relatively minor fluctuations - a wetter phase during the first and the second centuries A.D., a dryer phase during the third century A.D., and another wetter phase between approximately the fifth and eighth centuries A.D.

(i I) CENTRAL ASIAN PRECIPITATION FROM DENDRODATA (FIGURES 8-9) A long tree-ring chronology from Dulan-Wulan in central China (sabina-Juniperus przewalskii) and long ENSOsensitive tree-ring records from New Mexico (Douglas firPseudotsuga menziesii; El Malpais National Monument 35.16 $6^{\circ}$, - I07.87 $7^{\circ}$ and the North Island of New Zealand (kauri-Agathis australis- $35.65^{\circ}, \mathrm{I} 74.29^{\circ}$ ) provide valuable information about precipitation. Resolution is annual and exactly dated; each series extends back more than 2,000 years, overlapping with the Roman period.

For the ENSO climate pattern, see the National Oceanic and Atmospheric Administration website at http://www.esrl.noaa. gov/psd/enso/. The sabina data provided by Paul Sheppard and Lisa Graumlich are not yet available online. The Douglas fir data are available at ftp://ftp.ncdc.noaa.gov/pub/data/paleo/treering/ measurements/northamerica/usa/nm572.rwl. The raw data measurements are at ftp://ftp.ncdc.noaa.gov/pub/data/paleo/treering/ chronologies/northamerica/usa/nm572.crn The kauri data are on loan from Anthony Fowler and Gretel Boswijk, Auckland University, and not yet publicly available. Data were also generated and contributed by Jonathan Palmer, Gondwana Tree-Ring Laboratory, Canterbury, New Zealand.

Sea and Northern Red Sea during the Holocene and the Arctic/North Atlantic Oscillation," Paleoceanography, XXI (2006), PAioo8; Gerry Lemcke and Michael Sturm, " $\delta{ }^{18} \mathrm{O}$ and Trace Element Measurements as Proxy for the Reconstruction of Climate Changes at Lake Van (Turkey): Preliminary Results,” NATO ASI Series, CXLIX (I997), 653-678. 


\section{Supplementary Online Materials}

\section{Color Figures for:}

Michael McCormick, Ulf Büntgen, Mark A. Cane, Edward R. Cook, Kyle Harper, Peter Huybers, Thomas Litt, Sturt W. Manning, Paul Andrew Mayewski, Alexander F. M. More, Kurt Nicolussi, Willy Tegel, "Climate Change during and after the Roman Empire: Reconstructing the Past from Scientific and Historical Evidence," Journal of Interdisciplinary History vol. 43, number 2 (Autumn 2012), pp. 16-220. 


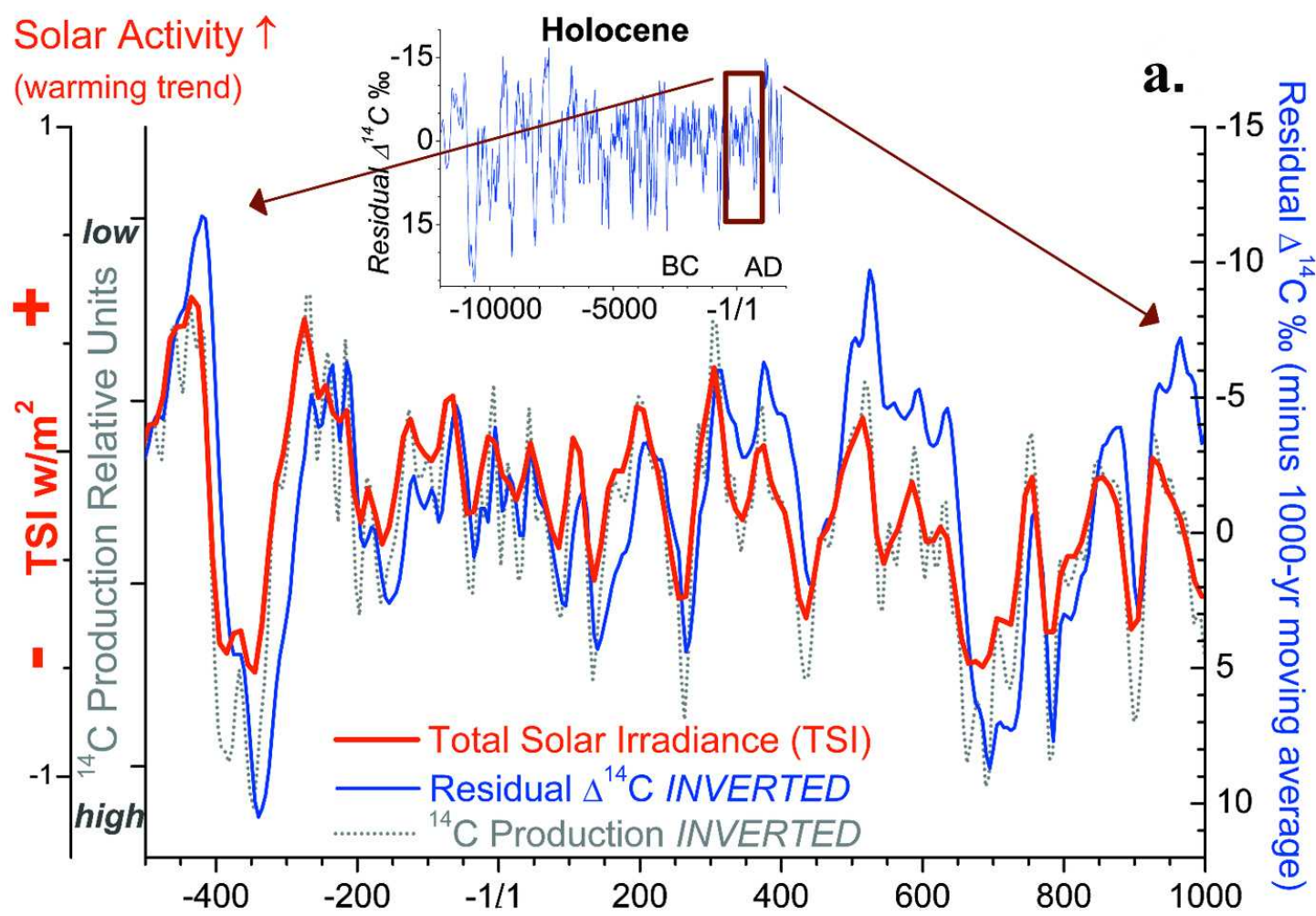

Solar Activity $\downarrow \quad$ Calendar Date BC / AD (cooling trend)

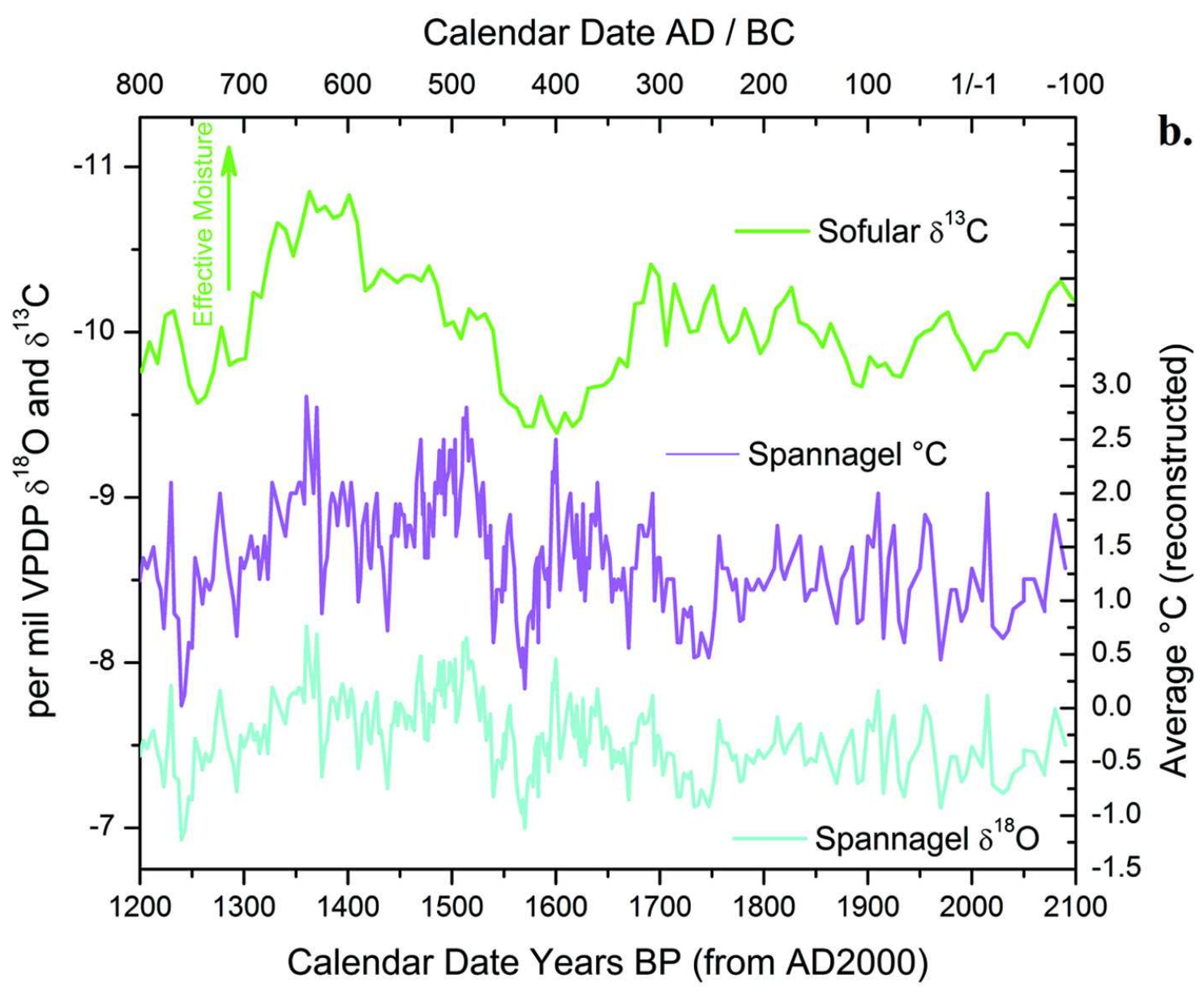


a.

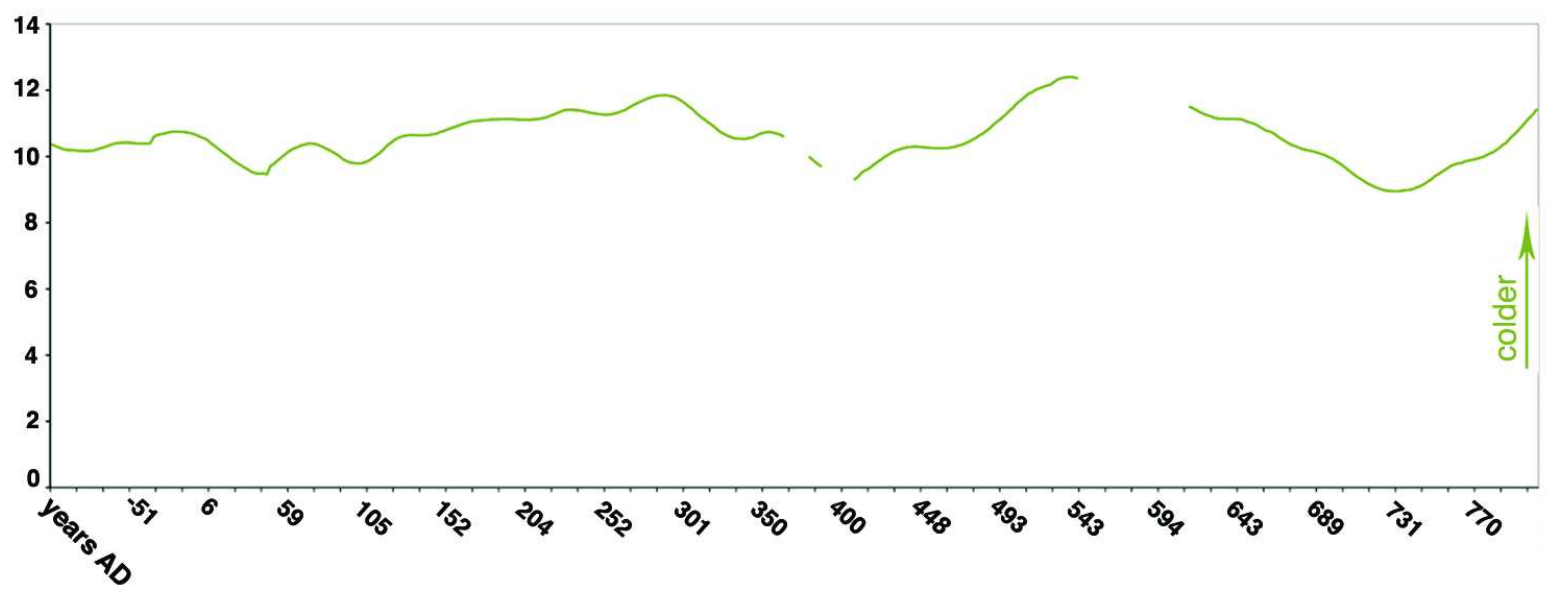

b.

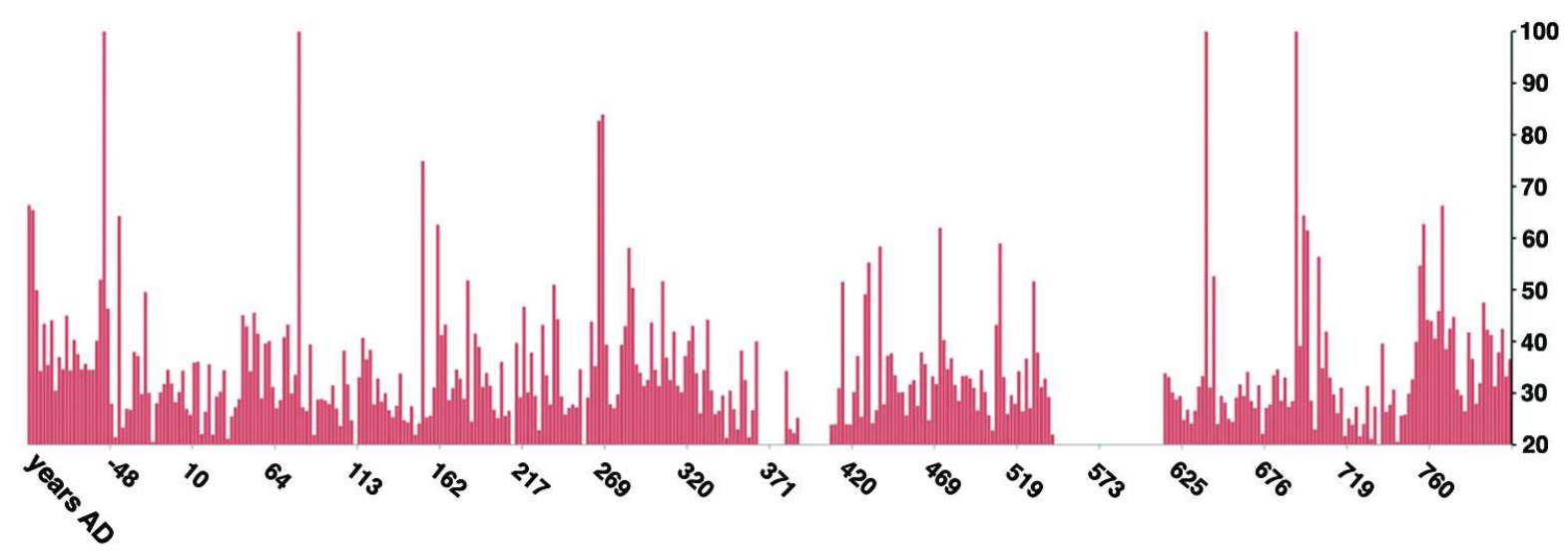

c.

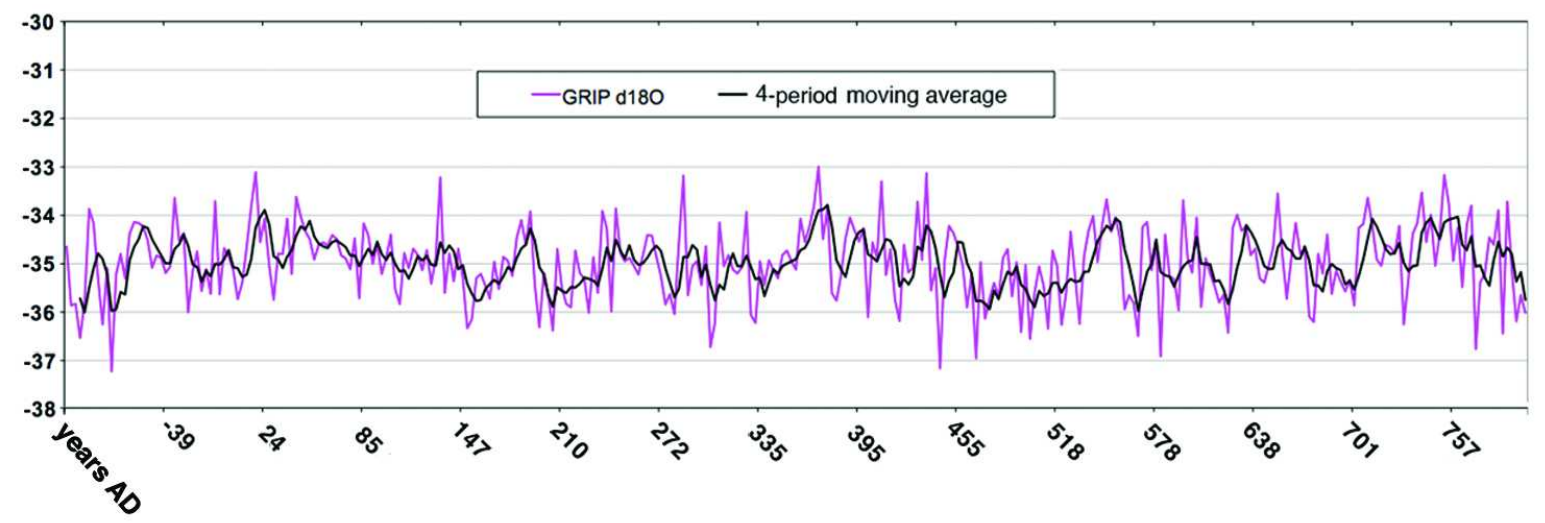




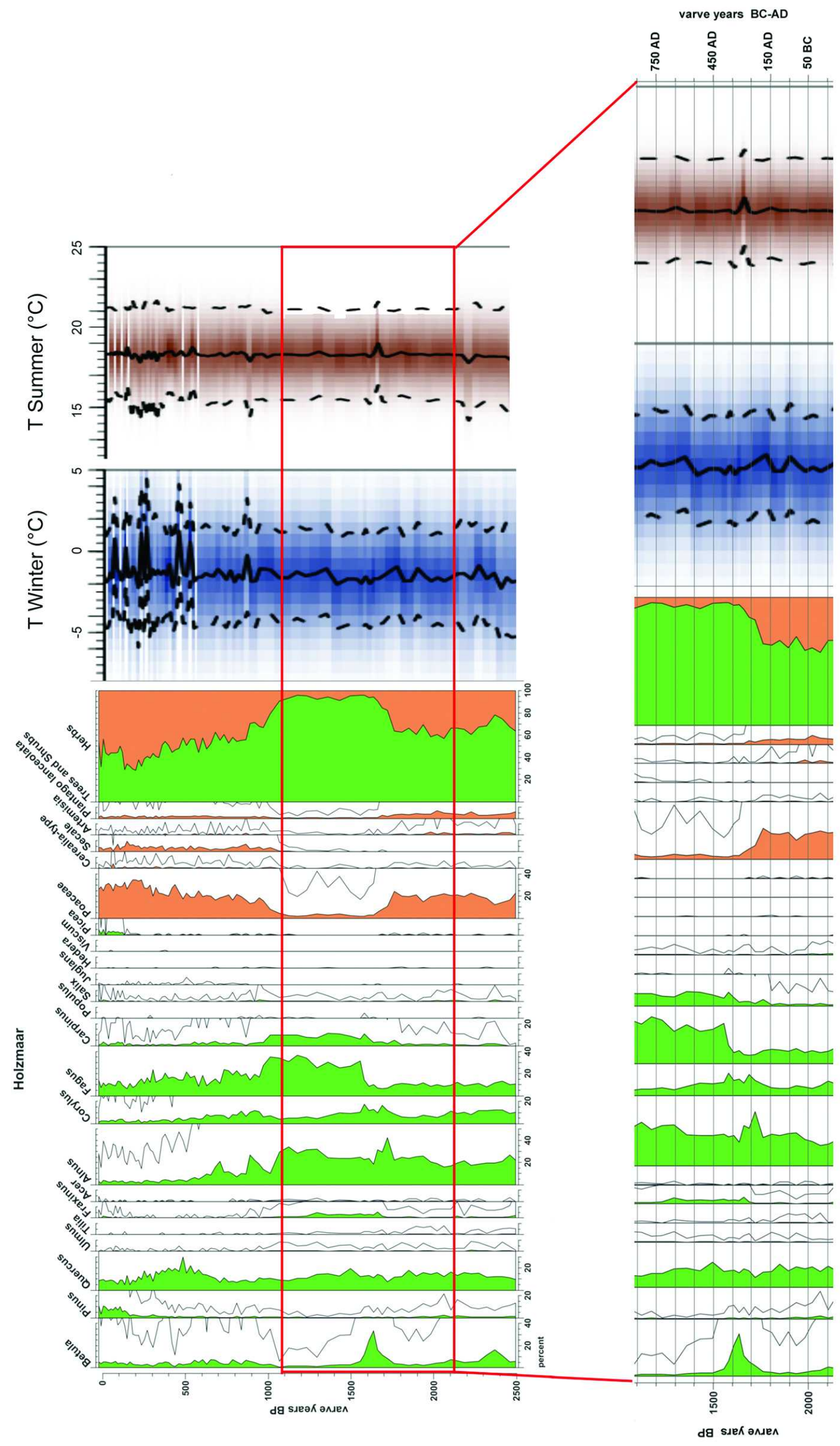




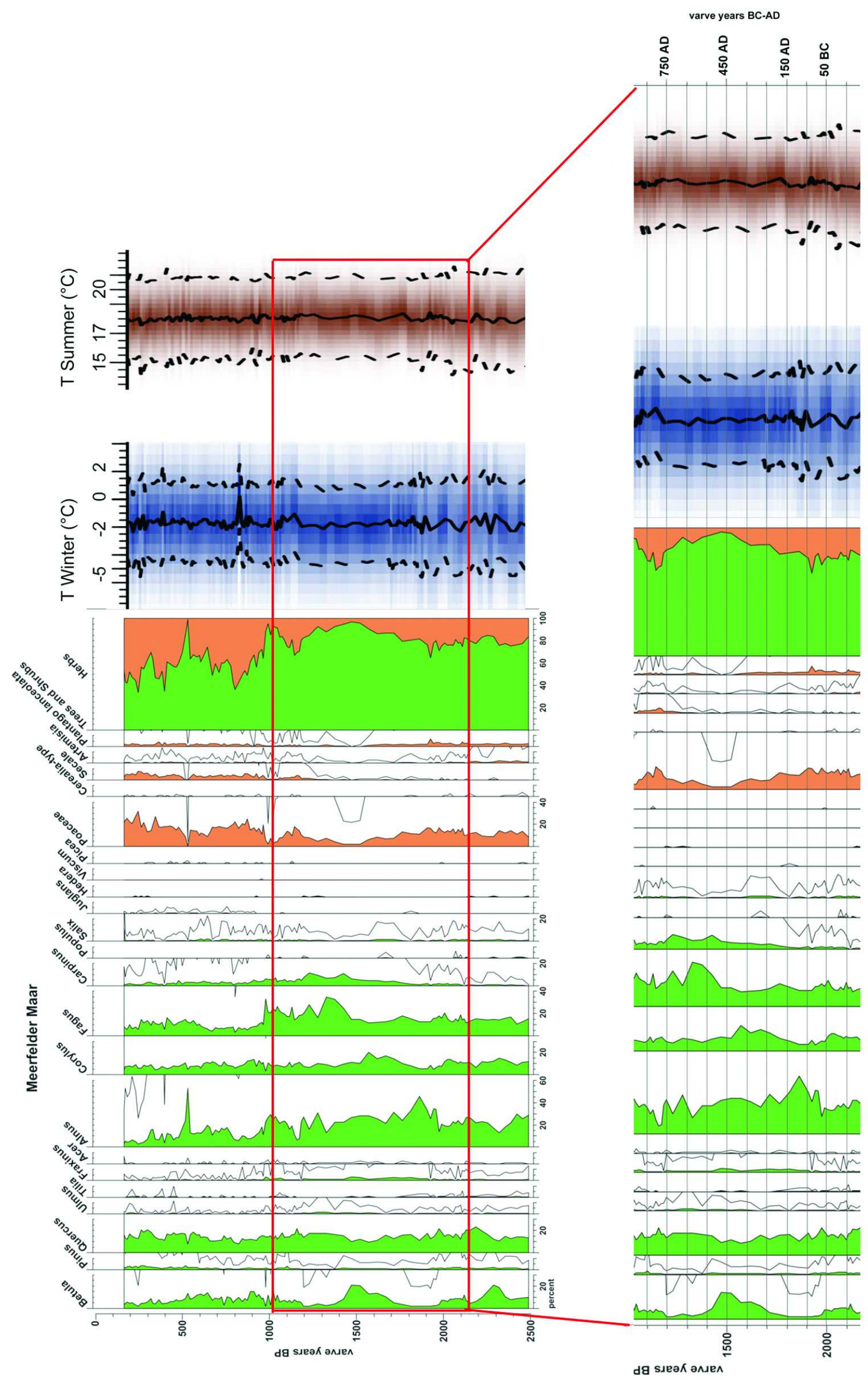



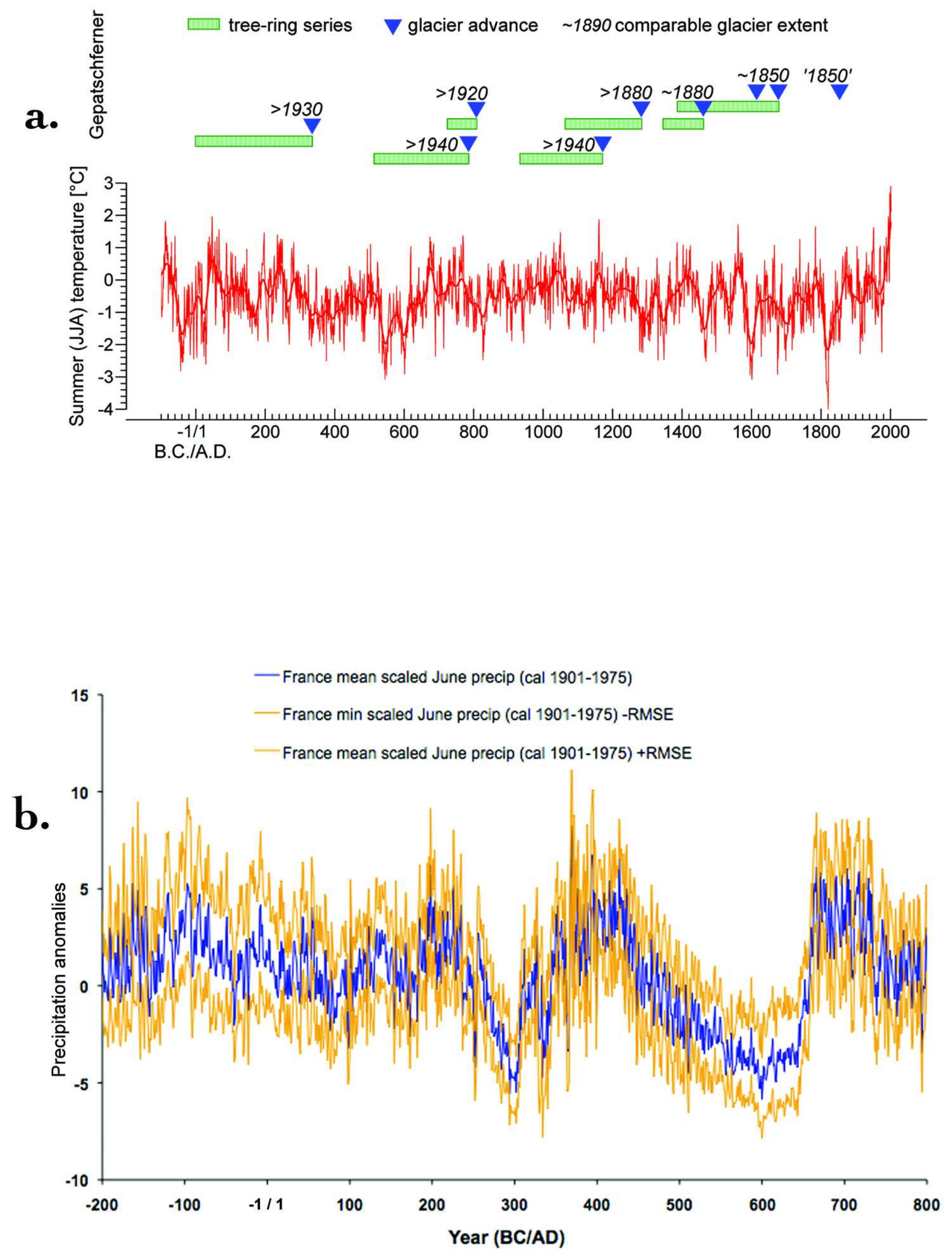

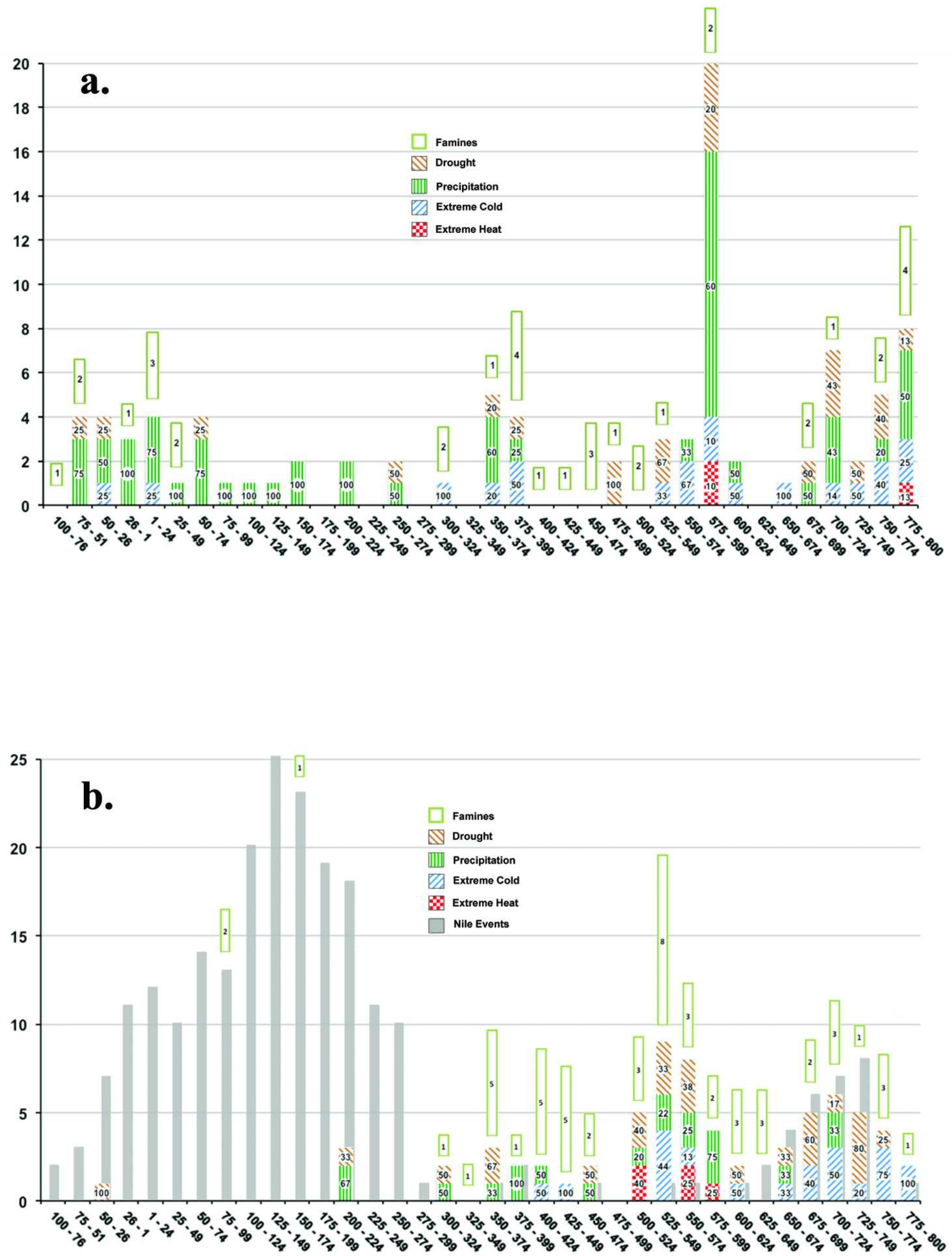

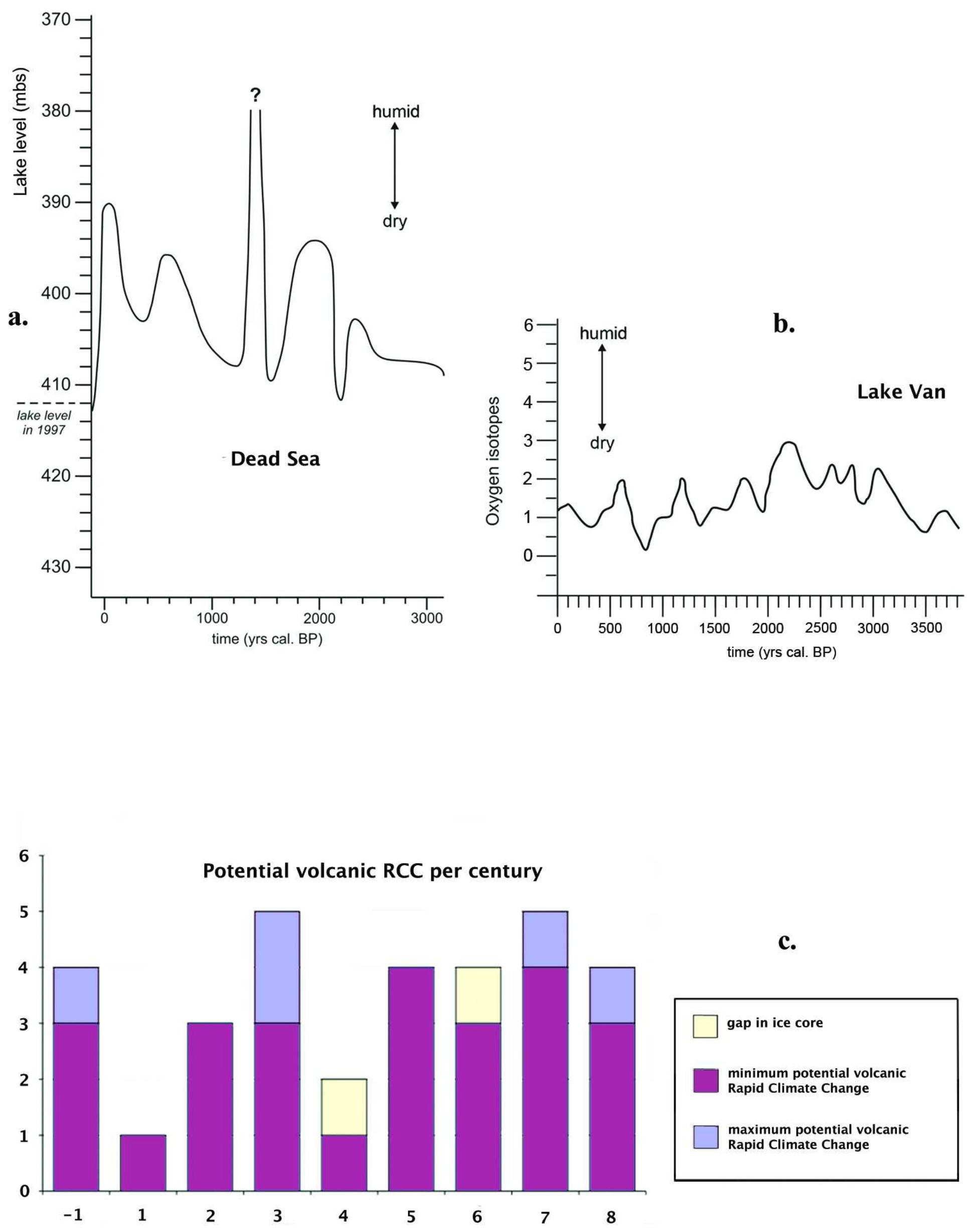

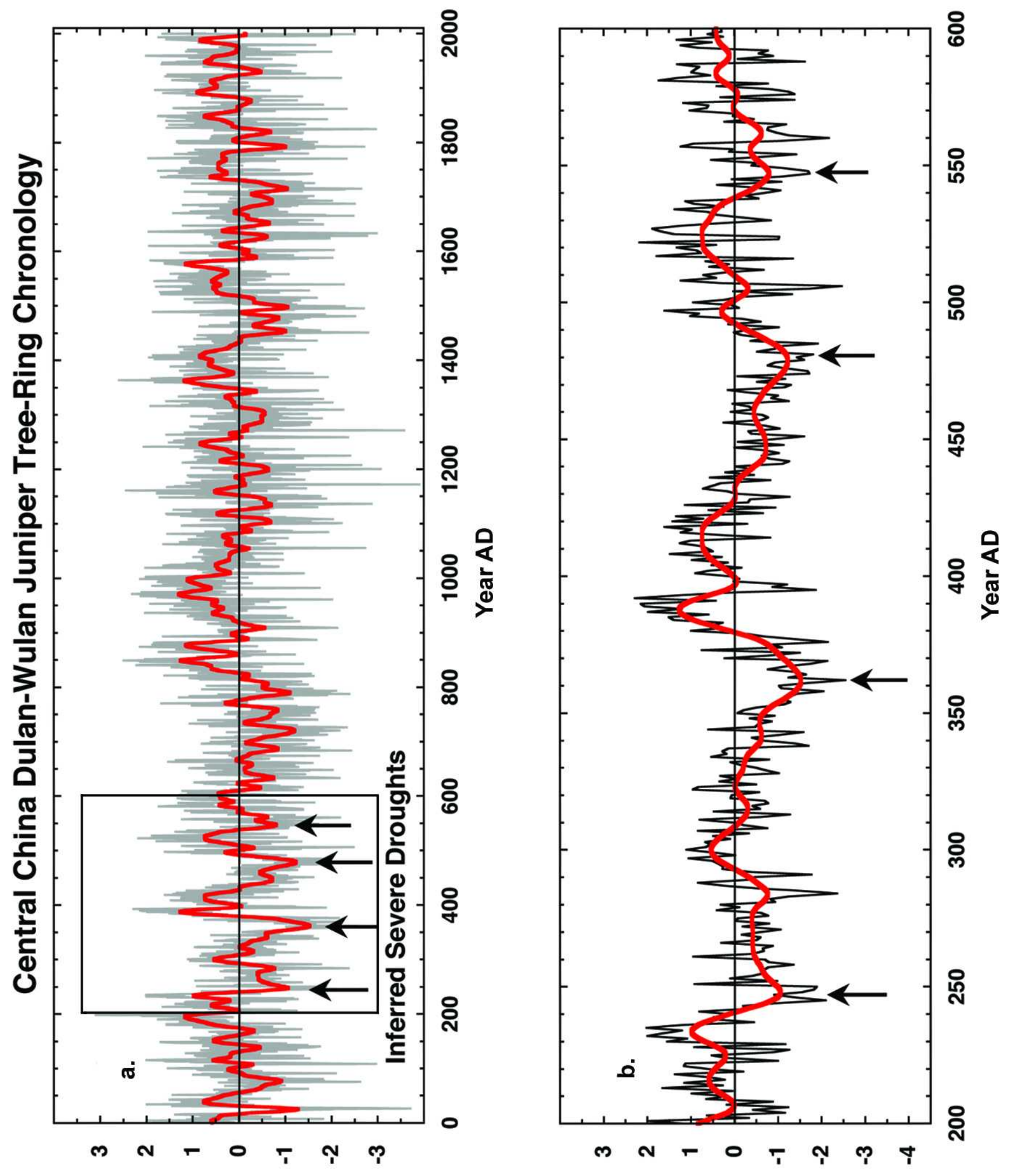


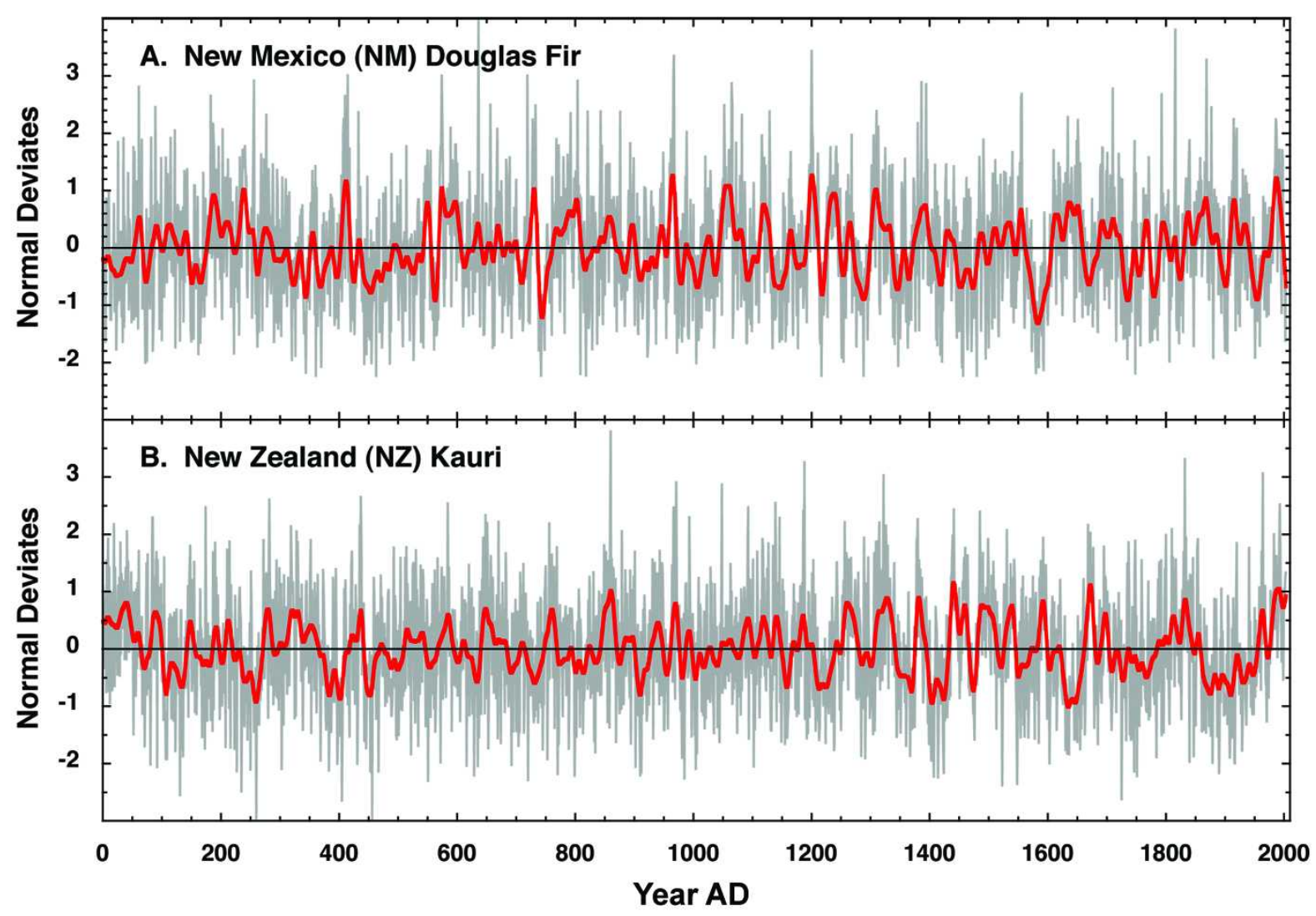

a.

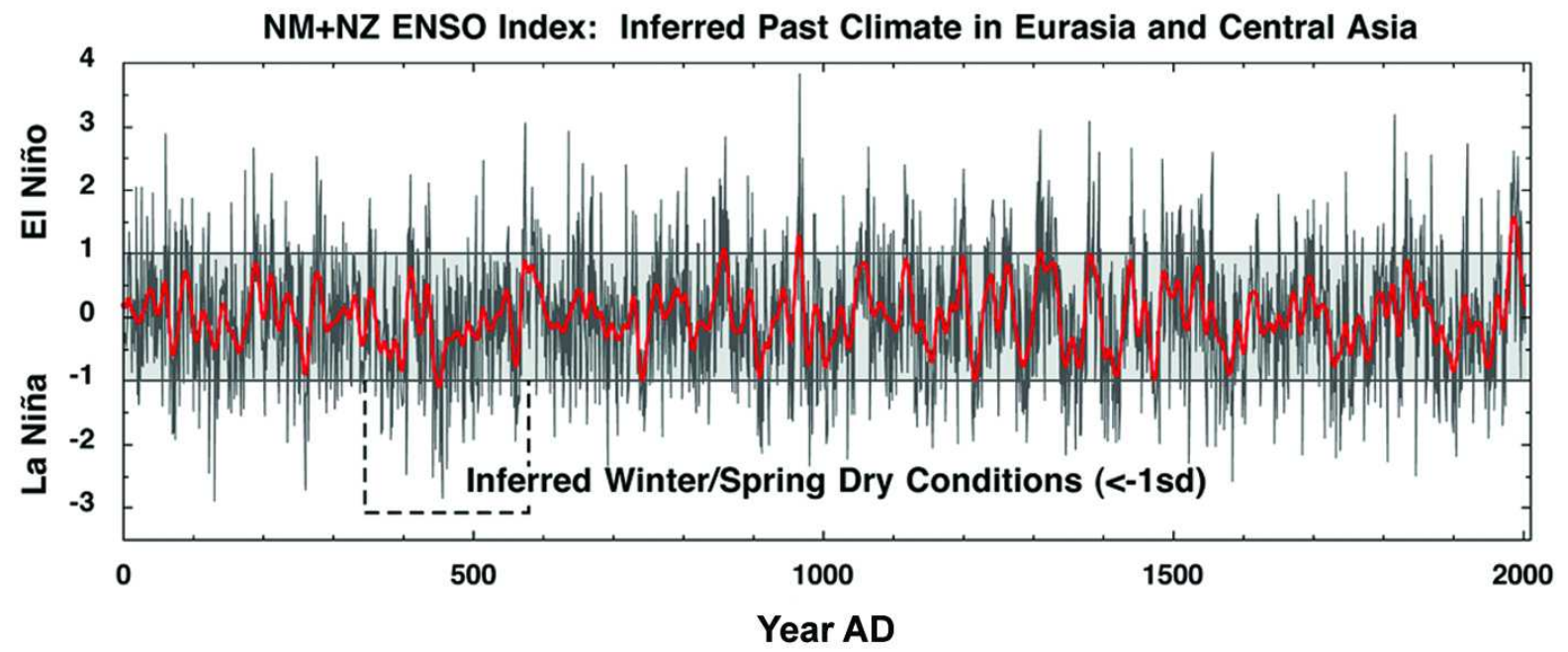

b.

Dec-May Precipitation Correlations with NM+NZ ENSO Index

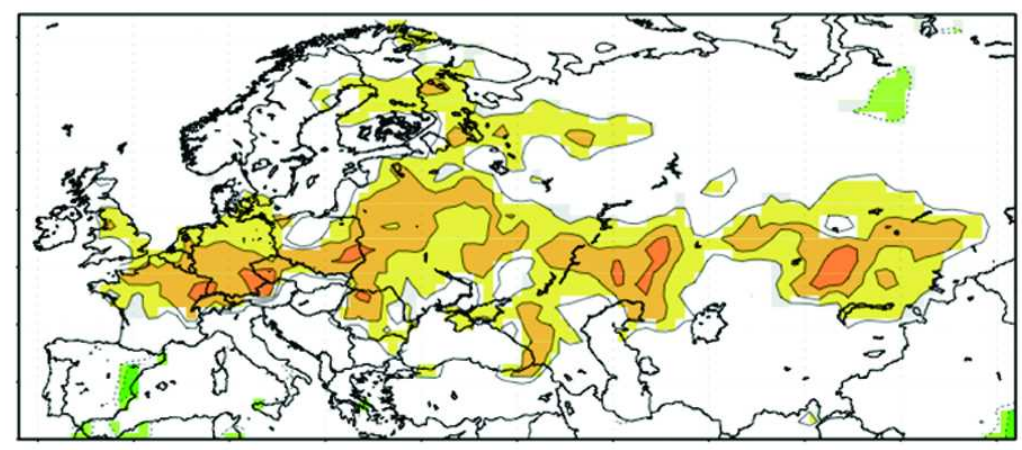

c. 


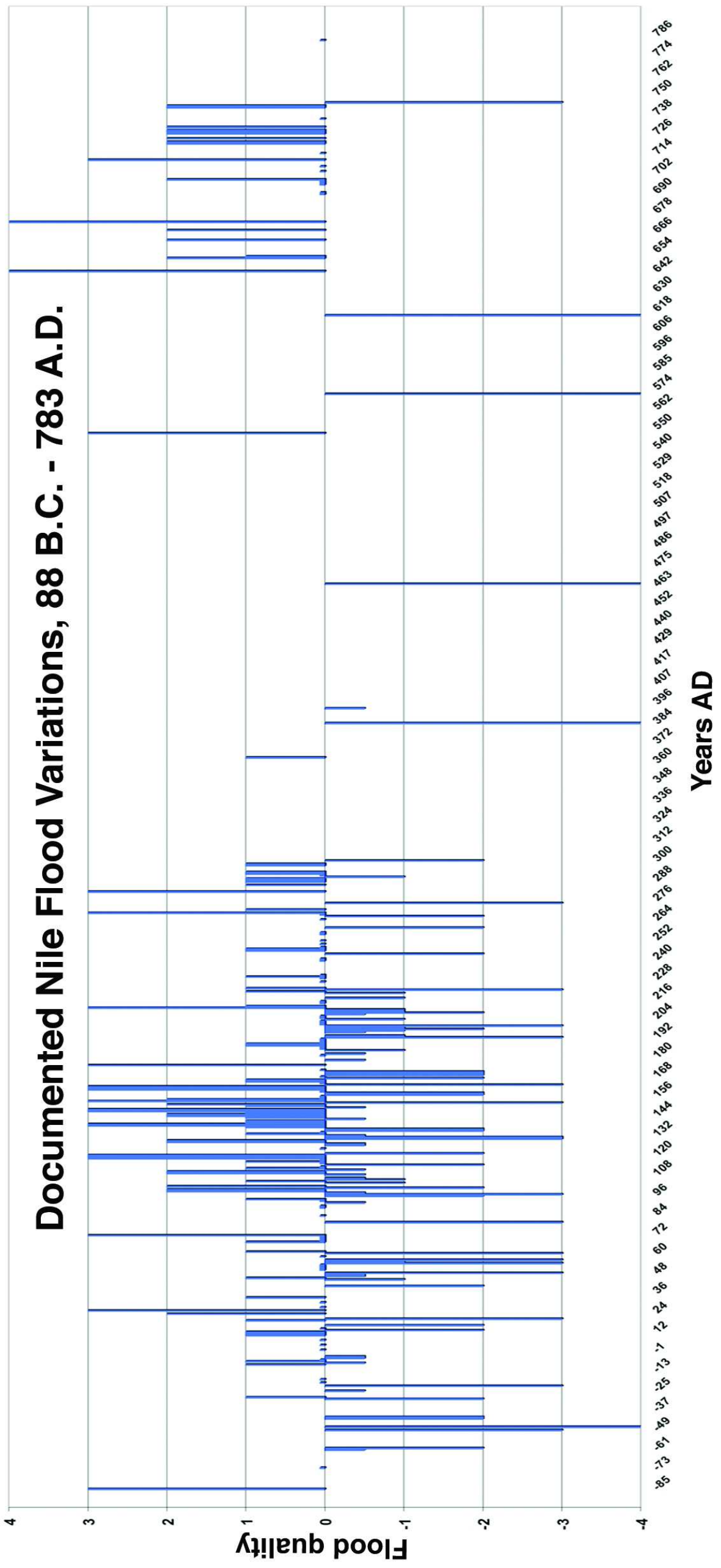




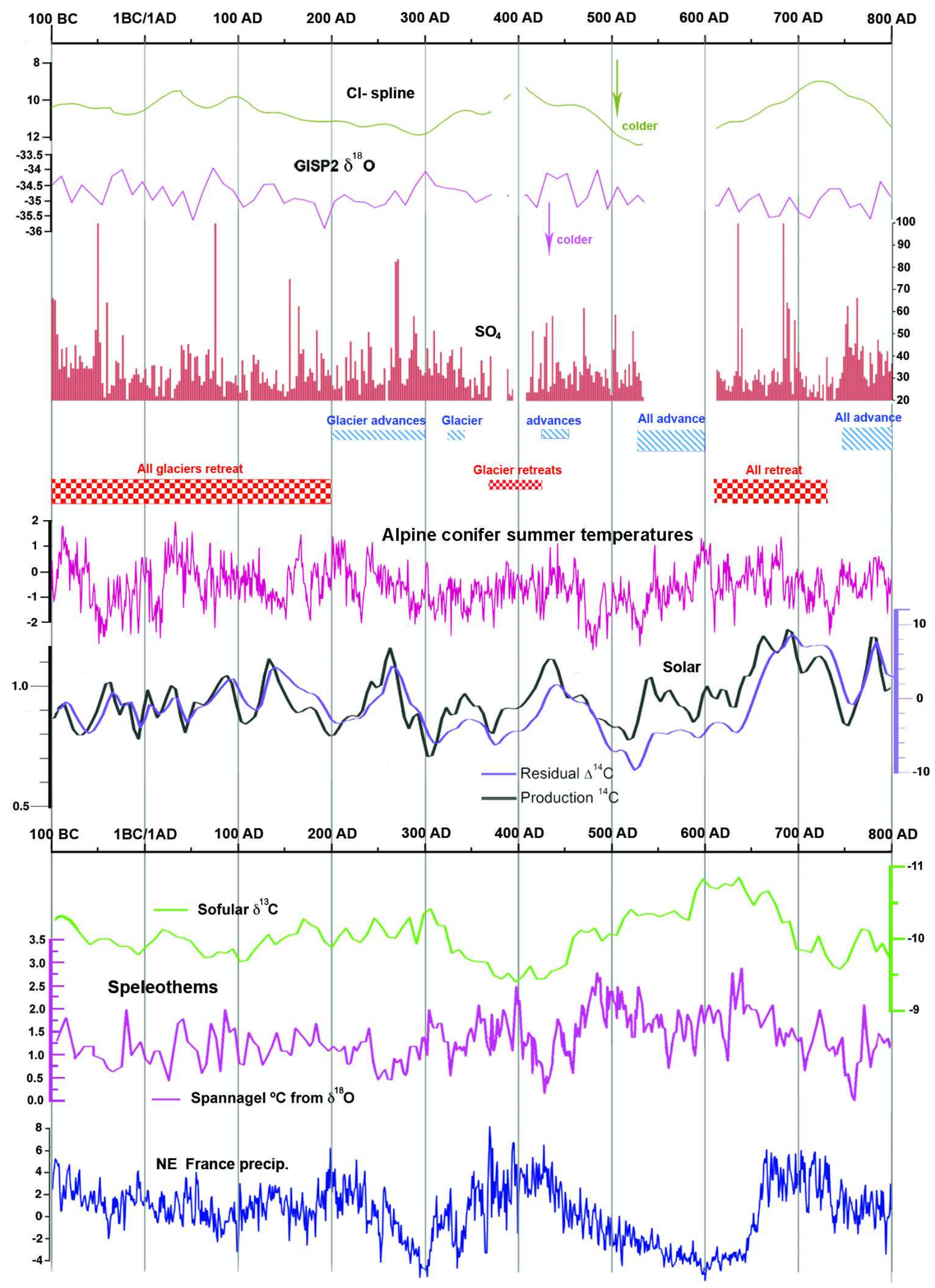

